American University Washington College of Law

Digital Commons @ American University Washington College of

Law

Articles in Law Reviews \& Other Academic Journals

Scholarship \& Research

1994

Give Them Back Their Lives: Recognizing Client Narrative in Case

Theory

Binny Miller

Follow this and additional works at: https://digitalcommons.wcl.american.edu/facsch_lawrev

Part of the Law Commons 


\title{
GIVE THEM BACK THEIR LIVES: RECOGNIZING CLIENT NARRATIVE IN CASE THEORY
}

\author{
Binny Miller*
}

\section{INTRODUCTION}

In recent years the concepts of lawyering as storytelling and client voice as narrative have come into vogue. ${ }^{1}$ As a practical matter, lawyers have always seen their work as in part "storytelling,"2 but only recently has legal scholarship framed lawyering in these terms. ${ }^{3}$ By and large, legal scholars have approached storytelling

* Associate Professor of Law, The American University, Washington College of Law. B.A. 1978, Carleton; J.D. 1983, University of Chicago. - Ed. I thank Robert Dinerstein, David Chavkin, Stephen Ellmann, and Nancy Polikoff for thoughtful responses to earlier drafts of this article, David Marin and Sara Shepard for helpful research assistance, and the participants in the Mid-Atlantic Clinical Theory and Practice Workshop and the New York Law School Clinical Theory Workshop for valuable comments. I am especially indebted to Miriam Ruttenberg for wide-ranging research support and astute feedback about the ideas in this article, Liz Seaton for incisive editing and farseeing conversations about the politics of sexual orientation and case theory, and my colleagues in the clinical program at The American University, Washington College of Law, whose insights about lawyering have shaped my work as a clinical teacher and scholar. I also thank my partner Ruth Eisenberg and my friend Michele Wolin for their generous personal support. Because all writing builds on lessons from the past, I dedicate this article to the memory of my mother, who loved unstintingly through pain and adversity, and who taught me the significance of perspective and the value of empathy.

1. See Symposium, Lawyers As Storytellers \& Storytellers As Lawyers: An Interdisciplinary Symposium Exploring the Use of Storytelling in the Practice of Law, 18 VT. L. REv. 565 (1994); Symposium, Legal Storytelling, 87 Mich. L. REv. 2073 (1989); Symposium, Speeches from the Emperor's Old Prose: Reexamining the Language of Law, 77 CORNELL L. REv. 1233 (1992).

2. See, e.g., Clark D. Cunningham, A Tale of Two Clients: Thinking About Law as Language, 87 Mrch. L. Rev. 2459, 2463 (1989); Steven Lubet, The Trial as a Persuasive Story, 14 Am. J. Trial Advoc. 77, 77 (1990); Sharon Creeden, Telling Your Client's Story to the Jury, TENN. B.J. May-June 1991, at 10, 10.

3. See, e.g., Charles R. Lawrence, III, The Word and the River: Pedagogy as Scholarship as Struggle, 65 S. CAL. L. Rev. 2231, 2278 (1992); Kim Lane Scheppele, Foreword: Telling Stories, 87 Mrсн. L. Rev. 2073, 2073 (1989). The relationship between law, storytelling, and progressive lawyering is brilliantly portrayed by Gerald Lopez, perhaps the foremost proponent of this genre, in his path-breaking work Rebellious Lawyering. See Gerald P. LOPEZ, Rebellious Lawyering: One Chicano's Vision of Progressive Law Practice (1992). For a thoughtful analysis of Lopez's ideas, see Anthony V. Alfieri, Practicing Community, 107 HARV. L. Rev. 1747 (1994) (book review). The idea of voice and narrative is also the focus of much academic literature from other disciplines, including literature, anthropology, political science, and history. See, e.g., JAMEs MCPHERson, BATtLE CRY OF FreEdOM: THE CIVIL. WAR ERA at ix-x (1988). For a critique of the legal narrative movement, see Daniel A. Farber \& Suzanna Sherry, Telling Stories Out of School: An Essay on Legal Narratives, 45 STAN. L. Rev. 807, 840-54 (1993) (arguing that objective standards should be used to evaluate narratives and that much narrative scholarship falls short of these standards). 
and narrative from the standpoint of theory - critical race theory, 4 critical literary and legal theory, ${ }^{5}$ feminist theory, ${ }^{6}$ lesbian and gay theory, ${ }^{7}$ and ethnographic theory. ${ }^{8}$ In contrast, clinical theory has long grounded narrative in the actual practice of lawyering.9 The emerging theoretics of practice literature draws on all of these vantage points in looking at the intersection of theory and practice in legal advocacy. ${ }^{10}$

Although these approaches differ in some respects, they share enough in common that they can be grouped under the rubric of "critical lawyering." 11 These critical theorists posit that client voices have been muted by the narratives that lawyers tell on their behalf, and urge lawyers to set aside their own stories in favor of client stories. ${ }^{12}$ They follow in the footsteps of the client-centered 2278 .

4. See, e.g., Derrick Bell, AND We ARE Not SAVEd (1987); Lawrence, supra note 3, at

5. See, e.g., Patricia J. Williams, The Alchemy of Race and Rights (1991).

6. See, e.g., Kathryn Abrams, Hearing the Call of Stories, 79 CAL. L. Rev. 971 (1991); Carol Weisbrod, Divorce Stories: Readings, Comments and Questions on Law and Narrative, 1991 B.Y.U. L. REv. 143, 143-46.

7. See, e.g., William N. Eskridge, Jr., Gaylegal Narratives, 46 STAN. L. Rev. 607 (1994); Marc A. Fajer, Can Two Real Men Eat Quiche Together? Storytelling, Gender-Role Stereotypes, and Legal Protection for Lesbians and Gay Men, 46 U. MIAMI L. REv. 511 (1992).

8. See, e.g., Clark D. Cunningham, The Lawyer as Translator, Representation as Text: Towards an Ethnography of Legal Discourse, 77 CoRNELL L. REV. 1298, 1339-57 (1992).

9. See generally Symposium, The Many Voices of Clinical Legal Education, 1 CLINICAL L. REv. 1 (1994).

10. Ann Shalleck, Constructions of the Client Within Legal Education, 45 STAN. L. REv. 1731,1748 (1993) (calling this work a "growing body of work that attempts to unite theory and practice"); Lucie E. White, Seeking ". . . the Faces of Otherness...": A Response to Professors Sarat, Felstiner, and Cahn, 77 Cornell L. Rev. 1499, 1503 (1992) (defining theoretics of practice as "a new field of critical reflection on advocacy and pedagogy"). For examples of works in this genre, see Symposium, Theoretics of Practice: The Integration of Progressive Thought and Action, 43 Hastings L.J. 717 (1992), and sources cited supra in note 1. Much of this literature tilts toward theory rather than practice by drawing broad conclusions about the attorney-client relationship. Robert D. Dinerstein, $A$ Meditation on the Theoretics of Practice, 43 Hastings L.J. 971, 983-85 (1992). For a discussion of the difference between theory and practice, see Stanley Fish, Dennis Martinez and the Uses of Theory, 96 YALE L.J. 1773, 1779 (1987) (defining theory as a "formulation that guides or governs practice from a position outside any particular conception of practice"); Gary L. Blasi, What's A Theory For? Notes on Reconstructing Poverty Law Scholarship, 48 U. MIAMI L. REv. (forthcoming May 1994).

11. See Stephen Ellmann, Empathy and Approval, 43 Hastings L.J. 991, 1013 n.64 (1992). These approaches are not mutually exclusive, nor do they exhaust the possibilities of critical theory. See Anthony V. Alfieri, Stances, 77 Cornell L. REv. 1233, 1235 (1992) (describing this body of scholarship as "inchoate and perhaps irresolvable").

12. See Anthony V. Alfieri, Speaking Out of Turn: The Story of Josephine V., 4 GEo. J. Legal Ethics 619, 632 (1991) [hereinafter Alfieri, Mrs. V.] (urging lawyers to "overturn lawyer narrative and install a self-proclaimed client narrative"); Anthony V. Alfieri, The Antinomies of Poverty Law and a Theory of Dialogic Empowerment, 16 N.Y.U. REv. L. \& Soc. Change 659, 665 (1987-88) [hereinafter Alfieri, Dialogic] (arguing that traditional legal approaches to poverty law silence clients in favor of attorneys). When the notion of "excluded" or "suppressed voices" is extended to legal educators, see, e.g., Anthony V. Alfieri, The Poli- 
movement, which has argued that clients should play a greater role in their own cases.

The critical and client-centered movements add to our understanding of the role that client voices can and should play in legal representation. But in the rush to embrace client voice, these scholars have virtually ignored the critical role that case theory can play in linking client stories to the narratives that lawyers tell on behalf of clients.

Case theory - or theory of the case - can be seen as an explanatory statement linking the "case" to the client's experience of the world. It serves as a lens for shaping reality, in light of the law, to explain the facts, relationships, and circumstances of the client and other parties in the way that can best achieve the client's goals. ${ }^{13}$ The relevant reality combines the perspectives of the lawyer and the client with an eye toward the ultimate audience - the trier of fact.

Despite the view of many lawyers that case theory is central to the task of lawyering, ${ }^{14}$ and despite its prominence in highly publicized trials, ${ }^{15}$ most accounts of lawyering do not explore the richness of case theory. ${ }^{16}$ For writers of trial advocacy texts, case theory is an important lawyering "skill," yet their works contain at best only skeletal analyses of the concept. For client-centered theorists, case theory plays little role in client decisionmaking; at best, it is one of a number of decisions that permit some client participation, and at worst, it is a task for lawyers alone. For critical theorists, both the concept of case theory and the role of clients in decisionmaking about case theory remain partially obscured.

tics of Clinical Knowledge, 35 N.Y.L. ScH. L. REv. 7, 7 (1990), the concept loses much of its force.

13. This definition captures my reformulation of case theory, described infra in Part III, in contrast to the traditional concept, set out infra in section I.A. For a provocative analysis of the relationship between client life experience and criminal responsibility, see Abbe Smith, Criminal Responsibility, Social Responsibility, and Angry Young Men: Reflections of a Feminist Criminal Defense Lawyer, 21 N.Y.U. Rev. L. \& Soc. ChaNGe (forthcoming 1994).

14. See sources cited infra note 30 . For excellent accounts of the pedagogical role of case theory in a law school clinic, see Nancy Cook, Legal Fictions: Clinical Experiences, Lace Collars and Boundless Stories, 1 Clinical L. Rev. 41 (1994); Dinerstein, supra note 10; and Ann Shalleck, Clinical Contexts: Theory and Practice in Law and Supervision, 21 N.Y.U. Rev. L. \& SoC. Change 109 (1993-94). For a description of the importance of case theory to trial advocacy courses, see Edward D. Ohlbaum, Basic Instinct: Case Theory and Courtroom Performance, 66 Temp. L. REv. 1 (1993), and Steven Lubet, Ethics and Theory Choice in Advocacy Education, 44 J. LEGAL EDUc. 81 (1994) (criticizing Ohlbaum for not focusing on ethical issues in theory development).

15. See infra notes $308,320-57$ and accompanying text.

16. See Ohlbaum, supra note 14 , at 16-17 (noting the absence of scholarship examining case theory). 
This article is about case theory and its implications for incorporating client narratives in litigation. ${ }^{17}$ In seeking to understand the connections between voice, narrative, and case theory, I look not only to theory but to my experience as a clinical teacher and criminal defense attorney. ${ }^{18}$ I explore how the practice of lawyering can be reconstructed to embrace a greater role for clients in constructing case theories, both through the images of the client the lawyer presents in the case theory and through active client participation in developing and choosing the case theory. ${ }^{19}$ Although one aim of case theory is to persuade the trier of fact, my focus is not on the sorts of inferences and arguments that might persuade a jury but rather on the role of the client in shaping case theory.

In Part I, I explain what case theory is, what it does, and how a lawyer develops a theory for a particular case. I then discuss the limited role clients play in developing and choosing case theory in the eyes of both trial advocacy writers and the client-centered movement. Finally, I consider how the critical theorists' emphasis on power dynamics and client narrative can be translated to case theory. Although these three models offer some important insights into case theory, ${ }^{20} \mathrm{I}$ conclude that they are ultimately unsatisfying in weaving clients' stories into case theory or in giving clients power to make decisions about how their cases are presented.

17. Although case theory is an equally important tool in the context of negotiation and transactions, see Robert M. BAstress \& Joseph D. HARbaugh, INTERviewing, Counseling, AND Negotiating: Skills for EFFective Representation 201 n.3 (1990), I concentrate on its use in trial preparation and trial. Case theory considerations may be similar in trial and nontrial contexts, $i d$., but to the extent that they vary, focusing on a single context avoids overbroad conclusions.

18. I have taught for the past seven years as a clinical teacher in a criminal defense clinic and have thought a great deal about the importance of case theory to the work of defending our clients. These insights, gained from this practice and my experience as a poverty law and civil rights attorney, are an important piece of my understanding of case theory. For an eloquent explanation of the relationship of experience to theory in a different context, see Myles Horton, The Long Haul 140 (1990) (noting that the philosophy of the Highlander Folk School challenged the traditional practice of "coming from the top down and going from the theoretical to the practical").

19. Although this article is intended primarily to describe a view of case theory that informs both theory and practice, it also speaks to the question of how to teach case theory, as any effort to teach a subject begins with the question "What is this thing that I am trying to teach?" For an interesting account of the need to incorporate client stories in legal pleadings, see Herbert A. Eastman, Speaking Truth to Power: The Language of Civil Rights Litigators, 104 YAle L.J. 763 (1995).

20. Although these models are characterized by important differences, they also overlap to some extent. See Alfieri, supra note 11, at 1233-35 \& nn.1-2 (describing lawyering models as falling along a "modern-postmodern" spectrum). For a thoughtful analysis of how traditional legal education leaves clients out of discussions of how to frame legal arguments, see Shalleck, supra note 10, at 1736. 
In Part II, I tell the story of a criminal case in which the issue of race played a key role in my clinic students' development of the case theory. Our client, a black man, was charged with disorderly conduct, resisting arrest, and assault and battery after he was stopped and wrongly accused of shoplifting by three white security guards. ${ }^{21}$ The case raised provocative questions about the relevance of our client's life experience to the various case theories that we, as his lawyers, could construct on his behalf.

I use one client's story as the backdrop to my discussion of case theory; this choice creates a tension between the story and the theory. 22 Few articles in the story-theory genre find comfortable ground in the often awkward fit between story and theory, where stories either serve as a perfunctory reference for "theoretical" conclusions, ${ }^{23}$ or instead carry the entire weight of the article. ${ }^{24}$ I seek to integrate the two by using the theory to explain the story and the story to critique and revise the theory. Through this back-and-forth interplay, theory can inform practice, and practice can give meaning to theory. ${ }^{25}$

In Part III, I offer my conclusions about how to reconstruct case theory to capture more fully the perspectives of clients. Although the context - both the situation of our client and criminal practice more generally - is crucial, my conclusions about case theory ap-

21. The racial connotations make it tempting to compare this case to the Rodney King case. Although King was a victim and a prosecution witness, the defense portrayed him as a criminal defendant first and foremost, as is common in police brutality cases. Like King, our client is a large black man, who was alternatively portrayed as soft-spoken or hostile and dangerous in his encounter with the police. See Bill Girdner, Different Result in New Cop Trial, A.B.A. J., June 1993, at 16; infra sections II.A, II.B.2.a. Yet this analogy is both overstated and understated. In our case, the stop of our client was less justified than in King's case, but the subsequent police conduct was less outrageous.

22. See Jane Spinak, Reflections on á Case (of Motherhood), at cover memo (Mar. 13, 1992) (unpublished manuscript, on file with author) (noting the difficulty of moving from client narrative to a theoretical construct).

23. See, e.g., Anthony V. Alfieri, Reconstructive Poverty Law Practice: Learning Lessons of Client Narrative, 100 YALE L.J. 2107 (1991).

24. See Spinak, supra note 22, at cover memo.

25. See Richard A. Boswell, Keeping the Practice in Clinical Education and Scholarship, 43 Hastings L.J. 1187, 1194 (1992) (proclaiming the need for more clinical scholarship that relates theory to experience); see also LOPEZ, supra note 3, at 65 (arguing for more "theories from the ground up"); Dinerstein, supra note 10 (arguing that the theoretics of practice movement has much to offer legal practitioners); Phyllis Goldfarb, Beyond Cut Flowers: Developing a Clinical Perspective on Critical Legal Theory, 43 HAstings L.J. 717 (1992) (examining the relationship between the clinical and critical legal studies movements in the context of theory and practice); Phyllis Goldfarb, $A$ Theory-Practice Spiral: The Ethics of Feminism and Clinical Education, 75 MINN. L. REv. 1599 (1991) (exploring the relationship between theory and practice from the standpoint of the clinical and feminist movements). 
ply across a wide range of lawyering. ${ }^{26}$ In reimagining client participation in case theory development, I draw from images pioneered by the critical lawyers and return to the story from Part II to offer some new images our client's story suggests. In coming full circle from the perspective of race to sexual orientation and back again, this concept of case theory as life experience demonstrates the elusive truth of what happened in any case. It also reveals how our own experiences as lawyers shape - for better or worse - the stories that we perceive and elicit from our clients.

\section{The Role of Case Theory in Lawyering}

There is little empirical evidence about the role case theory actually plays in the practice of law. ${ }^{27}$ The lone published study, whose participants were criminal defense attorneys, suggests that fewer than half of the attorneys surveyed typically develop a case theory before negotiating with the prosecutor. ${ }^{28}$ The wording of the survey question, however, makes this conclusion suspect, ${ }^{29}$ and the participants may not be representative of criminal defense lawyers as a group or of lawyers in other kinds of practices. In contrast, anecdotal evidence - including articles in practitioner-

26. See Robert D. Dinerstein, Client-Centered Counseling: Reappraisal and Refinement, 32 ARIz. L. REv. 501, 583 n.372 (1990) (explaining that the interests of clients facing abuse and neglect charges are similar to those of clients facing criminal charges); William $\mathrm{H}$. Simon, The Ethics of Criminal Defense, 91 Mrcr. L. REv. 1703, 1721-22 (1993) (rejecting traditional justifications for ethical differences between criminal and civil practices). But see Fred C. Zacharias, Rethinking Confidentiality, 74 Iowa L. Rev. 351, 357-58 nn.26-27 (1989) (suggesting that ethical considerations in civil and criminal cases differ).

27. This mirrors the absence of empirical evidence generally about what lawyers actually do. Dinerstein, supra note 10, at 987 ("Ultimately the theoretics literature must forge links with empirical work about lawyers and lawyering to fully ground its observations about the world of practice."); see also DAVID A. BINDER ET AL., LAWYERS AS CounsElors: A Client-CENTEREd APPROACH 269 n.30 (1991) (noting the absence of empirical work in this area).

28. See Robert L. Doyel, The National College - Mercer Criminal Defense Survey: Preliminary Observations about Interviewing, Counseling, and Plea Negotiations, 37 MERCER L. REv. 1019, 1027 (1986) (finding that criminal defense attorneys conduct a thorough investigation, do legal research, and develop a case theory before plea bargaining only $43 \%$ of the time).

29. The survey likely understates the role of case theory in the practice of survey participants, who responded to a three-part question worded in the conjunctive: "In what percentage of your cases did you conduct a thorough investigation, do legal research, and develop a theory of defense before plea negotiations?" Id. at 1027. The lawyers who developed a tentative theory before negotiating would have answered "no" to the question unless they also fully investigated the facts and conducted legal research. 
oriented publications ${ }^{30}$ and media accounts of trials ${ }^{31}$ - suggests that case theory plays a prominent role in legal representation. While lawyers often disparage their opponents' cases as "just" theory, ${ }^{32}$ their own case theories are almost sacred.

Despite its importance, case theory has received little attention in standard texts on lawyering. ${ }^{33}$ Some authors make only passing reference to the idea, ${ }^{34}$ while even those authors who see case theory as a key piece of case planning, strategy, and analysis do not explore the idea in any detail..$^{35}$ It is easier to explain the function of case theory than to define it; as a result, the term often is used imprecisely. ${ }^{36}$ Until we share a common understanding of the meaning of case theory, we cannot fully appreciate the importance of the concept or of the client's role in developing case theory.

30. See, e.g., James W. McElhaney, Focus, A.B.A. J., May 1991, at 78 [hereinafter McElhaney, Focus] (illustrating the need for a focus or theory during cross-examination); James W. McElhaney, Working the File, A.B.A. J., May 1994, at 84, 86 [hereinafter McElhaney, File] (noting the role of depositions in educating legal opponents about case theory); Paul J. Martinek, Bar Braces For Open Discipline: Dynamics Of BBO Advocacy To Change, Mass. LAw. WKLY., June 28, 1993, at 1, 32 (noting the need to "have the case theory down" early in lawyer disciplinary proceedings); see also Andrea D. Lyon, Defending the Death Penalty Case: What Makes Death Different?, 42 MERCER L. REv. 695, 711 (1991) (noting the need for trial and mitigation case theories to be congruent).

31. See infra section III.A.

32. See, e.g., Paul Duggan, Trial Begins in Slaying On Capital Hill in '92, WAsh. Post, June 23, 1993, at D3 (reporting a defense lawyer's characterization of the government's case as " "just a theory" "). In the novel by former assistant U.S. Attorney William Pease, detective Christine Boland characterizes police investigative work as "throwing theories around." William D. Pease, The Rage of Innocence 140 (1993).

33. See Ohlbaum, supra note 14 , at 4 (pointing out that traditional trial advocacy classes emphasize "skills and techniques ... at the expense of [] case theory"). My review of standard texts includes traditional pretrial and trial advocacy texts whose primary purpose is a "how-to" or skills focus, see Marilyn J. Berger et al., Pretrial Advocacy: Planning, ANalysis, and Strategy (1988) [hereinafter Berger Et al., Pretrial]; Marilyn J. Ber. ger et al., Trial Advocacy: Planning, Analysis, and Strategy (1989) [hereinafter Berger et al., Trial]; Thomas A. Mauet, Pretrial (2d ed. 1993); Thomas A. Mauet, Fundamentals of Trial Techniques (3d ed. 1992) [hereinafter Mauet, Trial], and more theoretical and client-focused texts, see BASTress \& HARBAUGH, supra note 17; GARY BELlow \& Bea Moulton, The Lawyering Process: Materials for Clinical INSTRuction IN ADVOCACY (1978); BINDER ET AL., supra note 27. For an analysis of the contributions of the client-centered writers to the question of who makes the decision about case theory, see infra section I.B.

34. See Roger S. Haydock \& David F. Herr, Discovery Practice 14 (2d ed. Supp. 1993) (listing notes about case theory among the contents of a litigation folder).

35. See, e.g., Bellow \& Moulton, supra note 33, at 305; Ronald L. Carison \& Edward J. Imwinkelried, Dynamics of Trial Practice: Problems and Materials 25, 35, 37 (1989); Elkan Abramowitz, Theory and Theme of the Case, in Master Advocates' HANDBOoK 1 (D. Lake Rumsey ed., 1986). For exceptions, see Berger ET AL., Pretrial, supra note 33, at 8, and BERGER ET AL., TRIAL, supra note 33, at 7-8.

36. See infra notes $64-68$ and accompanying text. 


\section{A. Traditional Model: Where is the Client?}

\section{Concept of Case Theory}

Case theory provides a framework for trial preparation and ultimately for trial. ${ }^{37}$ It has been defined as "the basic underlying idea that explains not only the legal theory and factual background, but also ties as much of the evidence as possible into a coherent and credible whole." 38 Case theory is not simply a statement of the applicable law or of the facts that support this legal interpretation, but rather it is the "basic concept around which everything else revolves." 39

Case theory is often described as comprising two separate theories, a legal theory and a factual theory. ${ }^{40}$ The legal theory is "a legal framework developed by a lawyer from interpretation, analysis, and expansion of legal rules and standards," 41 while the factual theory is "the party's 'story' justifying relief under the legal the-

37. Bellow \& Moulton, supra note 33, at 305; Berger Et Al., Pretrial, supra note 33 , at 18; Abramowitz, supra note 35, at 2. For the role of case theory in negotiation and transactional contexts, see supra note 17.

38. James W. McElhaney, Trial Notebook 78 (3d ed. 1994). For similar definitions, see BELLow \& MoulToN, supra note 33, at 305 ("a view of how fact, law and circumstance can be put together to produce the outcome you and your client seek"); MAUET, Trial, supra note 33, at 46 ("your side's version of 'what really happened" "); JAMES W. McElHA. ney; Effective Litigation: Trials, Problems and Materials 123 (1974) [hereinafter MCELHANEY, LITIGATION] ("a simple, believable, coherent progression with which you can explain all of your evidence and whatever is credible of your opposition's evidence"); J. AL. exander Tanford, The Trial Process: Law, Tactics and Ethics 51 (2d ed. 1993) ("a cohesive, logical view of the merits of the case"); and Ohlbaum, supra note 14, at 4 ("the basic, underlying and comprehensive idea that accounts for and explains all of the evidence").

39. McElhaney, Trial Notebook, supra note 38, at 78. For similar definitions, see David A. Binder \& Paul Bergman, Fact Investigation: From Hypothesis to Proof 184 (1984) ("describes what happened and why in a way that is persuasive both to the mind and to the heart"); John O. Sonsteng et al., The Trialbook: A TOTAL System for the Preparation and Presentation of a Case 3 (student ed. 1984) ("the central unifying concept of a case"); and George Vetter, Successful Civil Litigation - How to Win Your Case Before You ENTER THE Courtroom 21, 27 (1977) ("a perspective through which you want [the jury] to view the facts and assess what the case is all about").

40. Berger et Al., Pretrial, supra note 33, at 18 (stating that legal theory and factual theory are the two interdependent components that make up case theory); BERGER ET AL., TRIAL, supra note 33, at 16-17 (same); BINDER \& BERGMAN, supra note 39, at 184 (stressing the importance of combining a legal theory with a persuasive factual theory); SoNSTENG ET AL., supra note 39, at 4-5 (defining legal and factual theory).

41. Berger et Al., Pretrial, supra note 33, at 18. 
ory." 42 The case theory should be supported by the facts, ${ }^{43}$ meaning that it should explain the party's version of the facts, ${ }^{44}$ the unfavorable facts, ${ }^{45}$ and any undisputed facts. ${ }^{46}$ The theory must also be measured against its legal sufficiency ${ }^{47}$ and in terms of how well it responds to the likely theory of the opponent. ${ }^{48}$

The theory of the case should be expressed in simple declarative sentences ${ }^{49}$ that combine the legal theory with central factual assertions. ${ }^{50}$ Take, for example, a criminal case in which the defendant is accused of stealing two car seat covers that the owner last saw when he left them in his car, elevated on blocks in front of his home. The seat covers were later found in the defendant's car. The prosecution could assert that the defendant knew that the car seat covers belonged to someone else when he took them from the car and that he meant to deprive the car owner of his property. The defendant might respond that he took the seat covers because he believed that the car and its contents were abandoned. The car was stripped of its parts after it sat on blocks for over a month without being worked on. ${ }^{51}$

42. Id. Factual theories are also referred to as factual "summaries," see RoGer Haydock \& John Sonsteng, Trial: Theories, Tactics, Techniques 70 (1991), and as factual stories, see BINDER \& BERGMAN, supra note 39, at 169, and become "legal stories" when they satisfy a legal theory, id. at 175.

43. See, e.g., Berger et Al., Pretrial, supra note 33, at 19; Berger et Al., Trial, supra note 33, at 17-18; CARLSON \& IMWINKELRIED, supra note 35, at 30-33; VETTER, supra note 39 , at 30-33.

44. Bellow \& Moulton, supra note 33, at 305; Mauet, Pretrial, supra note 33, at 8889; MaUet, Trial, supra note 33 , at 46,380 ; MCElHaney, Trial NotebooK, supra note 38 , at 81 .

45. Bellow \& Moulton, supra note 33, at 305; VetTER, supra note 39, at 31.

46. Mauet, Pretrial, supra note 33, at 88; Mauer, Trial, supra note 33, at 46,380 ; VETTER, supra note 39, at 30-31.

47. See Berger et al., Pretrial, supra note 33, at 19; Berger et Al., Trial, supra note 33, at 17-18; MAUET, TriaL, supra note 33, at 46.

48. Bellow \& Moulton, supra note 33, at 305; Berger et al., Pretrial, supra note 33, at 27-28; Berger et AL., Trial, supra note 33, at 25-26; see also J. AleXANDER Tanford, Teacher's Manual, The Trial Process: Law, Tactics and Ethics 76 (1992). Case theory must take into account a grab bag of other variables, including jurisdictional considerations, applicable statutes of limitations, the availability of a bench trial or jury trial, and the wording of the relevant jury instructions. See CarLson \& IMWINKELRIED, supra note 35, at 32; McElhaney, Trial NotebooK, supra note 38, at 79.

49. HAYDOCK \& SONSTENG, supra note 42 , at 70.

50. The "plot" is the "skeleton" for the story, which consists of a string of "central assertions" about "what happened." BERGer ET AL., Pretrial, supra note 33, at 24; BERGER ET AL., TRIAL, supra note 33, at 22.

51. This example and the applicable case theories are taken from BERGer ET AL., PrETRIAL, supra note 33, at 28-31, and BERGER ET AL., TRIAL, supra note 33, at 27-31. Given a different set of factual assertions, other potential defenses could include a defense that the owner fabricated the charge, no asportation (taking), mistaken identification, insanity, duress, mistake, claim of right, or diminished capacity. BERGER ET AL., Pretrial, supra note 33, at 29; BERGER ET AL., TRIAL, supra note 33, at 27. 
Once a case theory is selected, 52 it serves as the centerpiece for all strategic and tactical decisions in the case..$^{53}$ The case theory is incorporated in the pleadings ${ }^{54}$ and serves as a guide for conducting the pretrial investigation and discovery, ${ }^{55}$ including client and witness interviews, formal discovery, and motions. ${ }^{56}$ Later, case theory "dictate[s] virtually every word the attorney utters at trial." 57 The theory of the case is not only stated explicitly in the opening statement ${ }^{58}$ and reiterated in closing argument, ${ }^{59}$ but it also shapes every aspect of the trial, including trial tactics, ${ }^{60}$ witness examinations, ${ }^{61}$

52. The lawyer should focus on narrowing the possible theories by the trial preparation and trial stages. BASTress \& Harbaugh, supra note 17, at 201; Berger Et AL., Pretrial, supra note 33, at 23; BERGER ET AL., TRIAL, supra note 33, at 21-22. In many instances, a single theory is preferable. BINDER \& BERGMAN, supra note 39 , at 167 n.3; MAUET, TRIAL, supra note 33, at 380; MCElhaney, TrIAL Notebook, supra note 38, at 84 ("Get a basket big enough and strong enough to carry all the eggs you need."). The risk of alternative theories is that weaker arguments can dilute the force of stronger ones. See Jones v. Barnes, 463 U.S. 745, 751-52 (1983) (discussing the strategic importance of "winnowing out weaker arguments on appeal and focusing on one central issue"). Moreover, the fact finder may become confused or distracted, see CARLSON \& IMWINKELRIED, supra note 35, at 31; Rooer S. Haydock et al, Fundamentals of Pretrial Litigation 14 (3d ed. 1994), or view the lawyer as not credible, CARLSON \& IMwinkELRIED, supra note 35 , at 30-31.

53. See Berger et Al., Pretrial, supra note 33, at 18; Berger et al., Trial, supra note 33, at 16; MAUET, TRIAL, supra note 33, at 280; Ohlbaum, supra note 14, at 17; Stephen C. Rench, Building the Powerfully Persuasive Criminal Defense, 42 Mercer L. Rev. 569, 578-80 (1991). The distinction between strategy and tactics and its relevance to client decisionmaking is discussed infra in section I.B.

54. MaUet, Pretrial, supra note 33, at 89-90. For strategic reasons, lawyers sometimes choose not to divulge their theories to their opponents. McElhaney, File, supra note 30, at 86.

55. Berger et AL, Pretrial, supra note 33, at 18, 194-95; Mauet, Trial, supra note 33 , at 380 . At this stage, the attorney may be relying on more than one theory, and these pretrial activities can serve as the basis for choosing between theories. See, e.g., BASTRESs \& Harbaugh, supra note 17, at 201; Berger Et AL., Pretrial, supra note 33, at 23, 28, 30, 54, 194-95.

56. Berger et Al., Pretrial, supra note 33, at 28, 30; Berger et Al., Trial, supra note 33, at 27, 29; BINDER \& Bergman, supra note 39, at 163 (noting that "[i]t is nearly impossible to question witnesses in the absence of some legal theory"). For a discussion of the relationship between a motions theory and a case theory, see Berger et AL., Pretrial, supra note 33, at 28, 253-58, and BERGER ET AL., TRIAL, supra note 33, at 27, 96-101.

57. CARLSON \& IMWINKELRIED, supra note 35 , at 35 .

58. Berger et al., Trial, supra note 33, at 27, 30; McElhanex, Trial Notebook, supra note 38, at 83; SONSTENG ET AL., supra note 39, at 185.

59. Berger ET AL., TRIAL, supra note 33, at 27; Sonsteng ET AL., supra note 39 , at 4; McElhaney, Litigation, supra note 38, at 123; McElHaney, Trial Notebook, supra note 38, at 83; Stuart M. Speiser, Closing Argument, in Master Advocates' HaNdBook, supra note 35 , at 235 . Thus, trial preparation should begin with closing argument, which is the piece of the trial that most explicitly states the theory of the case, and work backwards through the other pieces of the trial. See Bellow \& Moulton, supra note 33, at 305.

60. CARLSON \& IMWINKELRIED, supra note 35, at 35-36; Abramowitz, supra note 35, at 2 (advising lawyers not to impeach an opponent's witnesses if their testimony supports the client's case theory).

61. Berger et al., Pretrial, supra note 33, at 29 n.4; Berger et Al., Trial, supra note 33, at 27, 30-31; Christina L. Hunt, Calling Your Attention to the Direct Examination: How to Avoid the What Happened Next Question, 42 Mercer L. Rev. 619, 621 (1991). Case 
and evidentiary issues. ${ }^{62}$ Thus, a trial becomes a contest between competing theories of the case. ${ }^{63}$

Case theory remains an elusive concept, beyond the seemingly simple statement that case theory is the legal and factual framework for organizing and presenting a case. Lawyers often mistake case theory for narrow tactical decisions, ${ }^{64}$ and this confusion is compounded by the use of other terms that loosely approximate the idea of case theory but are not identical. While the terms theory of the case and theme are sometimes used interchangeably, ${ }^{65}$ they seem to mean different things. Theory implies a linear, rational concept that drives the fact finder inexorably to a favorable result; theme, while geared to the same end, instead suggests a potent mixture of facts and emotion. ${ }^{66}$ Other efforts to define case theory are

theory provides a way of looking at each witness as a part of an overall picture of the case, making witness examinations a slice of the theory that the attorney wants to convey, rather than a series of random questions. McElhaney, Focus, supra note 30, at 78 .

62. Berger et Al., Pretrial, supta note 33, at 30; Berger et AL., Trial, supra note 33, at 27-29; CARLSON \& IMWINKELRIED, supra note 35, at 33 (observing that by choosing among possible case theories, an attorney can control which facts become most relevant); Ohlbaum, supra note 14 , at $23,44-55$.

63. MAUET, TRIAL, supra note 33, at 46,381 . For a colloquial version of this principle, see McElHANEY, TRIAL NotebooK, supra note 38, at 78 (comparing case theory to a "home cave to be defended at all costs unless utter disaster commands that it be deserted in favor of some unfamiliar place further up the hill").

64. See McElhaney, Focus, supra note 30, at 78 (illustrating that lawyers often mistakenly equate the key witness examination points with the broader idea of case theory).

65. See Joan M. Brovins \& Thomas Oemmke, The Trial Practice Guide 236 (1992); Steven H. Goldberg, The First Trial: Where Do I Sir? What Do I Say? 63-64 (1982); SONSTENG ET AL, supra note 39, at 3-5. Other terms are slant, JAMES W. JEANS, Trial Advocacy 201 (student ed. 1975), principle, Brovins \& OefmKe, supra, at 236, and simply theory, BINDER ET AL., supra note 27, at 113-14, 145-64 (describing theory development and verification).

66. See, e.g., CARLson \& IMwinkelried, supra note 35, at 25-28 (explaining that theory is the set of specific facts that lead to a favorable conclusion and that theme is the recurring motif an attorney uses to show the jury why it should reach that conclusion); Abramowitz, supra note 35, at 1-2 (defining theory as "that explanation of the facts which shows logic requires your side to win," and theme as "that explanation of the facts which shows the moral force is on your side"); Patrick Bennett, An English Point of View, in MAster Advocates' HANDBOOK, supra note 35 , at 3 (defining theory as the factual explanation for what happened, and theme as the explanation for why one party is responsible and not the other); MAUET, TrIAL, supra note 33, at 380-83 (explaining that theory tells a story while theme summarizes key points in an "emotionally compelling" way); see also Charles L. Weltner, Thelema: The Desire to Help, in MASTER AdvOCATES' HANDBOOK, supra note 35, at 6-8 (defining theme and theory as the legal construct that presents the trier of fact with the means of coming to the desired conclusion, and thelema as that which makes the trier of fact want to reach the desired conclusion). 
colorful and quaint at best; ${ }^{67}$ at worst, they are cliches. ${ }^{68}$ The oftencited admonitions that case theory should be straightforward ${ }^{69}$ and consistent with common sense, ${ }^{70}$ human experience, ${ }^{71}$ and the values of the judge or jury 72 add little to these barebones explanations.

In addition, the structure for classifying case theory reveals the lack of clarity in the concept. This structure, as set out in texts authored by Marilyn Berger, John Mitchell, and Ronald Clark, ${ }^{73}$ and by David Binder and Paul Bergman, respectively, ${ }^{74}$ divides the universe of case theory into two categories. Affirmative theories state one party's version of what happened; 75 rebuttal theories respond to this version by probing weaknesses in the opposing side's case but do not offer an independent version of events. ${ }^{76}$

Whereas plaintiffs must offer an affirmative story, defendants can offer either affirmative or rebuttal stories, or both. ${ }^{77}$ Consider,

67. See, e.g., Abramowitz, supra note 35, at 2 (defining case theory as "the glue which holds together the other elements required for successful litigation"); Bennett, supra note 66, at 2 ("Before you choose your brushes or mix the paints, you decide first what you want the painting to look like and what effect you want it to have on the viewer.").

68. GoldBERG, supra note 65 , at 66 (defining case theory as "a little bit of law, a little bit of fact, and a dash or two of common sense").

69. See MAUET, Trial, supra note 33 , at 46 ; Ohlbaum, supra note 14 , at $18-23$ (noting ten principles of persuasion bearing on case theory).

70. MAUET, TRIAL, supra note 33, at 46; TANFORD, supra note 38, at 51; VETTER, supra note 39, at 31 (explaining that a case theory should be "down-to-earth and have a commonsense appeal").

71. MAUET, TRIAL, supra note 33, at 46 (stating that a case theory should fit the juror's "perception of how life works"); McElHANEY, Trial NoteBook, supra note 38, at 80 (urging that a case theory should resonate with what "the jury feels is more likely true"); Rench, supra note 53, at 571 (explaining that the theory should be consistent with jurors' belief systems, which are developed through life experiences).

72. Sonsteng et al., supra note 39, at 4; McElhaney, Trial Notebook, supra note 38 , at 81 .

73. See Berger et Al, Pretrial, supra note 33, at 17-51; Berger et Al., Trial, slupra note 33 , at $15-61$.

74. See Binder \& Bergman, supra note 39, at 162-89. To their credit, the Berger, Mitchell, and Clark texts and the Binder and Bergman text are the only lawyering texts that provide any guidance in thinking about case theory in a systematic way.

75. See Berger et al., Pretrial, supra note 33, at 19, 22-23; Berger et al., Trial, supra note 33 , at 17,21 ; BINDER \& BERGMAN, supra note 39 , at 13,174. Most of the citations to Binder and Bergman that follow refer to descriptive hypotheses, which together with explanatory hypotheses, id. at 174-78, and legal theories comprise case theory. Id. at 184. Although conclusions about descriptive hypotheses would seem to apply more generally to case theory, the conclusions may not be identical.

76. Berger et Al., Pretrial, supra note 33, at 20; Berger et Al., Trial, supra note 33, at 18; BINDER \& BERGMAN, supra note 39 , at 13, 174.

77. Berger et Al., Pretrial, supra note 33, at 19-20; Berger et Al., Trial, supra note 33 , at 17-18; BINDER \& BERGMAN, supra note 39 , at 13-14, 174-75. Because plaintiffs must respond to affirmative defense theories, the assertions about the rebuttal options for defendants may also apply to plaintiffs. BERGER ET AL., PRETRIAL, supra note 33, at 22; Berger ET AL., TRIAL, supra note 33, at 21; BINDER \& BERGMAN, supra note 39, at 174 n.12. For a discussion of the risks of offering alternative theories, see supra note 52. 
for example, a murder case in which the State asserts the affirmative theory that the defendant stabbed the victim. ${ }^{78}$ In response, the defendant could assert either the affirmative defense that he is not guilty by reason of insanity ${ }^{79}$ or a rebuttal theory that attacks the credibility of the eyewitness who identified him as the killer. ${ }^{80}$ Both affirmative theories commit to a story about what happened - the stabbing or the reason for the stabbing - while the rebuttal theory commits to nothing but simply asks the fact finder to reject the opponent's theory.

Despite its apparent simplicity, this classification scheme does not easily account for every kind of theory, nor does it avoid difficult questions about the category in which a particular theory belongs. In many respects, the two groupings overlap as much as they diverge. ${ }^{81}$ If the defendant asserts that he was insane when he committed the crime, that story both adds a new affirmative dimension to the story - the defendant's mental state - and also rebuts the prosecutor's version - which at least implicitly portrays the defendant as sane. By the same token, if the defendant attacks the credibility of the eyewitness to the crime, he not only undermines the State's case but also presents a fundamentally different picture of what happened. In the State's version, the crime was observed by a credible witness, even if the State does not offer direct evidence of credibility.

This structure for classifying case theory also reveals important differences both in how the authors assess the relative importance of facts and law to theory and in the role they create for defense counsel. The Berger, Mitchell, and Clark approach gives legal doctrine a greater role in both affirmative and rebuttal theories than does the Binder and Bergman approach. For Berger, Mitchell, and Clark, a theory must rest on statutory authority or case law to be classified as affirmative. ${ }^{82}$ In the four-part typology of rebuttal theories, three theories - legal insufficiency, factual insufficiency, and

78. BINDER \& BERGMAN, supra note 39 , at 15.

79. Id.

80. Id. at 15-16.

81. Id. at 15. Even the architects of this classification scheme disagree about how to classify some theories. In the murder case defense, the Berger, Mitchell, and Clark formulation of the affirmative-rebuttal dichotomy apparently would classify an alibi theory, or a theory that someone else committed the murder, as a rebuttal theory. See BERGER ET AL., Pretrial, supra note 33, at 20, 22; Berger ET AL., TRIAL, supra note 33, at 18, 20-21. The Binder and Bergman formulation, on the other hand, would characterize them as affirmative. See Binder \& BERGMAN, supra note 39, at 174-76.

82. Berger et Al., Pretrial, supra note 33, at 22-23; Berger et Al., Trial, supra note 33 , at 20. 
procedural aspects - assume a given set of facts in mounting legal challenges. ${ }^{83}$ Only the persuasive insufficiency theory is analogous to the Binder and Bergman notion that rebuttal theories tell a story. ${ }^{84}$ For Binder and Bergman, affirmative theories are found not only on the pages of law books but also in stories about what happened, ${ }^{85}$ and rebuttal theories are factually richer.

The role of defense counsel also differs in the affirmative-rebuttal dichotomy. The typical defense lawyer in the Berger, Mitchell, and Clark model passively resorts to blunting the plaintiff's attack, while in the Binder and Bergman model she is active and challenging. She has as many stories to tell as the lawyer for the plaintiff, ${ }^{86}$ and she offers these stories in both affirmative and rebuttal modes.

\section{Critique - Visible Doctrine and Invisible Clients}

The traditional concept of case theory provides a useful starting point for thinking about a case and a skeletal framework for mounting an attack or a defense. If the "facts" do not satisfy a necessary legal element, case theory cautions the attorney to focus on that element, rather than to attack every contention her opponent makes. For example, by focusing on case theory, a misidentification defense in a theft case is shown to bear little resemblance to a defense of no intent. ${ }^{87}$ Legal theories that are clearly inapplicable can be discarded in favor of better theories.

But in other respects this concept of case theory is impoverished. The meaning of case theory is not clear, and the concept is not explored in any depth. In worshiping the law, this notion of case theory ignores context and misconceives the power of impor-

83. See Berger et Al., Pretrial, supra note 33, at 20 (providing as an example of a legal insufficiency theory the argument that a criminal statute is unconstitutional); BERGER ET AL., TrIal, supra note 33, at 19 (same); Berger et AL., Pretrial, supra note 33, at 21-22 (providing as an example of a factual insufficiency theory the argument that the prosecutor has not made out a prima facie case); BERGER ET AL., TRIAL, supra note 33, at 19-20 (same); Berger et AL., Pretrial, supra note 33, at 22 (providing as an example of a procedural theory the argument that the court lacks jurisdiction); BERGER ET AL., TRIAL, supra note 33, at 20 (same).

84. Berger et Al., Pretrial, supra note 33, at 22 (providing as an example the theory that an eyewitness to a crime lacks credibility); BERGER ET AL., TRIAL, supra note 33, at 20 (same).

85. See Binder \& Bergman, supra note 39 , at 174-77.

86. Id. The thought process of defense counsel, however, differs from that of plaintiff's counsel in that defense counsel tend to focus their attack - whether affirmative or rebuttal - on one or more specific elements of the plaintiff's legal stories and typically should develop a theory that places the blame on another culprit. Id. at 175.

87. Berger et Al., Pretrial, supra note 33, at 29-30; Berger et Al., Trial, supra note 33 , at $27-28$. 
tant facts - especially the client's life facts. ${ }^{88}$ Traditionalists express too much objectivity about the "facts" and see a limited universe of case theory. Perhaps most importantly, this approach overlooks the insights that clients can bring to case theory and ignores the possibility that clients have other goals for case theory besides winning.

The heart of traditional case theory is what I call "elementcrunching": case theory is the law with facts playing a supporting role. ${ }^{89}$ Under this view, case theory is derived from the close study of court decisions, statutes, rules, regulations, and treatises. The attorney simply turns to these sources of information, determines which elements she needs to prove, and then gathers those facts that establish each and every element of her theory. 90

Legal doctrine is especially prominent in criminal cases, in which the reasonable doubt standard is heralded as the touchstone of a good defense theory. Defense counsel, who are not expected to tell a story, are relegated to poking holes in the prosecution's case or to suggesting hypothetical alternatives. ${ }^{91}$

Although the best of the traditionalists recognize a back-andforth interplay between legal theory and "what happened,"92 facts nonetheless serve a purpose secondary to legal doctrine. Even

88. See, e.g., BeRger ET AL., Pretrial, supra note 33, at 27-31 (making no mention of the character or circumstances of the defendant); BERGER ET AL, TRIAL, supra note 33, at 27-31 (same). But cf. Binder \& BERGMAN, supra note 39, at 178-81 (addressing the importance of emotional and socio-political themes in theories). One commentator recognizes the importance of these kinds of facts, which he calls "sex appeal" facts, although he does not connect this insight to case theory. See GoldBerg, supra note 65, at 100-02.

89. See, e.g., Berger et AL., Pretrial, supra note 33, at 18 (noting the importance of legal doctrines in developing a case theory); BERGER ET AL., TRIAL, supra note 33, at 16 (same); HAYDOCK ET AL., supra note 52, at 13-14 (using the term legal theory interchangeably with the overall concept of case theory); MAUET, TRIAL, supra note 33, at 380-81 (emphasizing the importance of legal elements in developing a case theory); TANFORD, supra note 48 , at 76 (including the identification of legal elements as a key component of developing case theory). Ironically, this is the "stuff" of traditional legal education, see CARLson \& IMWINKELRIED, supra note 35, at 29 (analogizing case theory development to taking a law school examination), which does not even recognize the concept of case theory.

90. See Bastress \& HaRBaugh, supra note 17, at 199 (describing the thought process in theory development as akin to a computer search).

91. Berger et Al., Pretrial, supra note 33, at 26; Berger et Al., Trial, supra note 33, at 24; BINDER \& BERGMAN, supra note 39, at $16 \mathrm{n} .12$ \& 184 (noting the frequency of this strategy in criminal defense practice). But see Rench, supra note 53, at 578 (arguing for a case theory that tells "the defense version of how the litigated event or episode happened"). For a discussion of the role of defense counsel, whether civil or criminal, see BERGER ET AL., PRETRIAL, supra note 33, at 20-23, 26-27, and BERGER ET AL., TRIAL, supra note 33, at 18-22, 24-25.

92. See, e.g., Berger et Al., Pretrial, supra note 33, at $27 \mathrm{n} .3$ (learning that the client was intoxicated may lead the lawyer to consider whether intoxication is a defense in a burglary prosecution); BERGER ET AL., TRIAL, supra note 33, at 25 n.4 (same); BINDER \& BerGMAN, supra note 39, at 162 (stating that legal theory flows from facts). 
when "factual theory" is identified as a piece of case-theory structure, this bipartite structure severs factual theory from legal theory. Stories are subsumed in legal theory, which serves as both the starting point and ending point for case theory. .33 Facts exist simply to be plugged into legal theory, and facts that cannot find a home in some legal element are deemed virtually irrelevant. ${ }^{94}$ The process of theory development is quantifiable, neat, and quite sterile.

For the traditionalists, there are a finite number of possible case theories in any case. ${ }^{95}$ If the lawyer is a good detective, she will ferret out all potential case theories, discard those theories that do not fit the facts, and from the remaining available theories select the one that is most persuasive. Yet even the novel theories she derives from creatively reading existing law or discovering new law ${ }^{96}$ lack the boundless possibilities that any one set of facts presents.

But traditionalists do not see these possibilities because they picture a world of objective facts in which the lawyer can really know "what happened" if only she pushes the right buttons. ${ }^{97}$ In their view, the worst kind of lawyer is one who "desperately grop[es] for anything in order to win, without any regard to what really happened." 98 In their rush to reject different factual scenarios, traditionalists provide no sense that objective facts are often

93. Berger ET AL, Pretrial, supra note 33, at 21 (determining factual sufficiency by reference to legal elements); BERGER ET AL., TRIAL, supra note 33, at 19-20 (same). The "fact" portion of case theory is typically addressed after the law, and many fewer pages are devoted to the discussion of facts than law. See Berger et AL., Pretrial, supra note 33, at 18-27; BERGER ET AL., TRIAL, supra note 33, at 16-25.

94. Berger et al., Pretrial, supra note 33, at 27 (positing that for any given legal theory, "there is a somewhat foreseeable spectrum of facts"); BERGER ET AL., TRIAL, supra note 33 , at 25 (same).

95. See Berger et Al., Pretrial, supra note 33, at 27, 29; Berger et Al., Trial, supra note 33 , at $25,29$.

96. Berger et al., Pretrial, supra note 33, at 154 (discussing "cutting-edge" theories); Charles J. Ogletree \& Randy Hertz, The Ethical Dilemmas of Public Defenders in Impact Litigation, 14 N.Y.U. Rev. L. \& Soc. Change 23, 37 (1986) (noting that new decisions and statutes "spawn a host of new legal challenges").

97. The analogy of case theory development to a computer search demonstrates this: A computer operator plugs a request into the computer; the computer scans its information bank and selects entries that satisfy the request; the operator then pursues the computer's responses to determine which best fits the immediate needs. Similarly, you begin with a set of facts provided by the client; you then plug that information into your bank of legal and nonlegal knowledge and scan all potential theories; after identifying the possible theories, you pursue additional information to either confirm or reject their application.

Bastress \& Harbaugh, supra note 17, at 199.

98. Berger et Al., Pretrial, supra note 33, at 23; Berger et Al., Trial, supra note 33 , at 22. Traditionalists similarly reject the use of multiple legal theories, see supra note 52 , but fail to distinguish doctrine from facts adequately. Whatever one's view of alternative fact scenarios, when a lawyer supplies alternative legal theories for a single set of facts, she 
few, that perspective is everything, and that what happened may be a meaningless concept apart from the lens of the particular viewer.

Contrast the traditionalist view with the videotape shown in the trial of the Los Angeles police officers charged with beating Rodney King. Although at first glance the videotape seemed susceptible to only one interpretation - a black man being brutally beaten by four white officers - the defense relied on the videotape to show King as a madman raging out of control. ${ }^{99}$ Even those jurors who were not persuaded that King was a madman experienced a "deadening" of facts through the constant replaying of the video, which at first seemed horrific.

Finally, clients are almost invisible in the traditional concept of case theory. Indeed, for some traditionalists, the process of defining the world of available theories begins even before the lawyer interviews the client. 100 Although others recognize that clients can serve as a source of factual "stories" in developing case theory"101 and may be counseled about the impact of a decision on the success of a particular case theory, ${ }^{102}$ this recognition does not translate into an active role for the client. The active role belongs to the lawyer and her view shapes the case theory. The real challenge for the lawyer lies in developing a viable case theory, ${ }^{103}$ not in understanding the client and her world. Lawyers are given the task of matching the theory to client goals, and clients are nearly always assumed to want to win, whatever the trade-offs. ${ }^{104}$ Even those tra-

merely suggests what most jurors probably believe - that the law is complicated and there may be more than one legal explanation for what happened.

99. See Girdner, supra note 21 , at 16.

100. See, e.g., Berger ET AL., Pretrial, supra note 33, at 18 ("[K]nowing as defense counsel that the defendant is charged with robbery will lead you to conjure up in your own mind and then research the range of possible theories of defense in that area."); BERGER ET AL., TrIal, supra note 33, at 16 (same). For other commentators, the client disappears after the initial interview, see, e.g., SONSTENG ET AL, supra note 39, or seems not to exist at all, see, e.g., HAYDOCK \& HERR, supra note 34. It is ironic that entire textbooks are devoted to trial practice "skills" in which clients are completely invisible.

101. See, e.g., Binder \& Bergman, supra note 39, at 162-63; Carlson \& IM WINKELRIED, supra note 35 , at 28-29; SONSTENG ET AL., supra note 39 , at 3 ; see also BASTRESS \& HARBAUGH, supra note 17, at 199.

102. While decisions such as whether the client should testify in a criminal case or undergo substance abuse counseling to assist her in participating in the case, see BERGER ET AL., Pretrial, supra note 33, at 28; Berger ET AL., TRIAL, supra note 33, at 27, can affect the success of a case theory that relies on the client's testimony, these decisions do not involve the client in decisions about case theory.

103. Berger et AL., Pretrial, supra note 33, at 18; Berger ET AL., Trial, supra note 33, at 16-17.

104. HAYDOCK \& Sonsteng, supra note 42 , at 70; VeTTER, supra note 39 , at $21,27,30$ 33. Even objectives that appear to look beyond winning are framed in terms of their effect on the client's chances of winning, see CARISON \& IMWINKELRIED, supra note 35, at 32 (describing a warranty theory that casts the client in a more winning role than does a breach 
ditionalists who recognize that an effective case theory should achieve the client's objectives give clients only a limited role in identifying objectives ${ }^{105}$ and assign them no role at all in selecting or shaping a theory to meet these objectives. ${ }^{106}$

The defense lawyer's "lecture" to his client about the law in Anatomy of a Murder ${ }^{107}$ stands as the classic example admonishing lawyers not to discuss case theory with their clients. In that book and in the movie version as well - the lawyer raises a potential insanity theory with his client and, through thinly veiled suggestion, deliberately encourages the client to adopt the story. The message is that a lawyer should obtain all the "facts" from clients without revealing potential theories; 108 otherwise, clients will shape their stories to fit the theory. ${ }^{109}$ Although in this example the attorney may have overstepped ethical boundaries by putting words in the client's mouth to fit the attorney's theory, ${ }^{110}$ the more unfortunate legacy of the story is that clients and case theory do not mix.

of contract theory), or on obtaining the desired relief, see BINDER \& BERGMAN, supra note 39 , at 166 (noting that an alibi defense is preferable to an insanity defense if the client wants a chance of release); CARLSON \& IMWINKELRIED, supra note 35, at 31 (providing an example in which a contract theory is preferable to a tort theory if the client wants specific performance).

105. See Berger et al., Pretrial, supra note 33, at 18, 27; Berger et Al., Trial, supra note 33, at 16-17, 25; CARLSON \& IMWINKELRIED, supra note 35, at 31 .

106. Although a few of the standard trial advocacy texts include clients in the discussion of litigation strategy and tactics, see HAYDOCK ET AL., supra note 52, at 25, none specifically include clients in the discussion of case theory. See supra note 102. Some simply fail to mention the client. See, e.g., HAYDOCK \& SonSTENG, supra note 42, at 74-75 (listing eight considerations in selecting a case theory, none of which refer to the client). Others go so far as to advise against the client having a role in case theory development. See, e.g., Abramowitz, supra note 35, at 2 (warning against "adopt[ing] blindly the theories of clients"). Even those commentators who suggest that the case should be assessed from some perspective other than the lawyer's, such as the opposing counsel's or the judge's, ignore the perspective of the client. See, e.g., HAYDOCK ET AL., supra note 52, at 14. In one 57-page article arguing for an expanded role for case theory in the law school curriculum, see Ohlbaum, supra note 14, the client is invisible.

107. Robert Traver, ANatomy of a Murder 35-49 (1958). The book was made into a movie, starring Jimmy Stewart as defense lawyer "Polly" Beigler. ANATOMY OF A MURDER (Columbia 1959). The story is widely cited in commentary on lawyering. See, e.g., MC. ElHaney, Trial Notebook, supra note 38, at 79; Stephen Ellmann, Lawyers and Clients, 34 UCLA L. REV. 717, 757 n.111 (1987).

108. For an analysis of whether it is desirable for lawyers to obtain all the facts, see Monroe H. Freedman, Professional Responsibility of the Criminal Defense Lawyer: The Three Hardest Questions, 64 Mich. L. Rev. 1469, $1472-73$ (1966).

109. See McElhaney, Trial Notebook, supra note 38, at 79 (stating that it impermissible to allow "legal theory [to] change any fact"). For a critique of this assumption, see infra Part III. For a wonderful account of how in scientific inquiry facts lack meaning in the absence of theory, see Lloyd Motz, Letter to the Editor, Kepler's Truth Is Beyond Calculation, N.Y. TIMEs, Feb. 13, 1990, at A24 (letter to the editor from professor emeritus of astronomy at Columbia University).

110. For a general discussion of the ethical limits on constructing case theory, see Lubet, supra note 14. See also McElhaNeY, Trial NoteBoox, supra note 38, at 79. 


\section{B. Client-Centered Theory: Who Decides?}

While the traditional model lays out the contours of case theory, the client-centered model calls attention to the issue that the identity of the person who makes the decision about case theory - the lawyer or the client - should be critical.111 In the context of a particular legal procedure - whether trial, negotiation, or settlement - what role can clients play in conceiving the strategy to carry out the procedure? Or more broadly, even outside the context of a particular decision, what role can clients play in simply conceiving of the case? What is the case and what does it mean to the client?

\section{Theory of Client-Centeredness}

In contrast to the traditional legal counseling model ${ }^{112}$ - which assigns a passive role to clients - client-centered counseling, or client decisionmaking, holds that lawyers should interact with clients in a way that allows clients to make decisions themselves. ${ }^{113}$ Together, the lawyer and her client consider the various alternatives available in the case and the likely consequences of these alternatives and then weigh the advantages and disadvantages of the alternatives in reaching a decision.114 Although the lawyer is an active participant in the decisionmaking process, she should ensure that her preferences do not override client choices. ${ }^{115}$

Client decisionmaking is supported by the principle of client autonomy and by the idea that the client is in a better position than the lawyer to evaluate alternatives and consequences. ${ }^{116}$ Under this

111. As one commentator aptly notes: " '[T] here are many stories in the naked city'.... We do have to make choices about stories and narratives." Carrie Menkel-Meadow, The Power of Narrative in Empathetic Learning: Post-Modernism and the Stories of Law, 2 UCLA WOMEN's L.J. 287, 306 (1992) (book review).

112. See Dinerstein, supra note 26, at 506 (describing the traditional model as lacking "meaningful interchange between lawyer and client"). I use the term traditional to provide an overview of the typical approaches reflected in case law, practice, and the professional codes.

113. BINDER ET AL., supra note 27, at 17; Dinerstein, supra note 26, at 507; Ellmann, supra note 107 , at 720 . Although this model has many variants, in this section I rely primarily on the model set out in Binder, Bergman, and Price's Lawyers as Counselors as the most typical model and the one most commonly used in legal education. See BINDER ET AL., supra note 27; see also Shalleck, supra note 10, at 1742 \& n.22. Some of the sources that I cite refer to an earlier edition, David A. Binder \& Susan C. PRICE, Legal Interviewing and Counseling: A Client-Centered Approach (1977).

114. BINDER ET AL., supra note 27 , at 290-308, 316-46.

115. Id. at 19-22; Dinerstein, supra note 26, at 507.

116. See BINDER ET AL., supra note 27, at 18; Dinerstein, supra note 26, at 512 (arguing that autonomy and socio-historical arguments provide the best support for client-centeredness). The "client knows best" argument differs from the autonomy argument, for which the 
view, the client has the right to make his own choices because it is he who stands to gain or lose the most from decisions made in his case.117 The client is also more knowledgeable than his lawyer about his individual concerns and how they mesh with the available legal alternatives. ${ }^{118}$ Because these nonlegal consequences often play a more important role than legal consequences, ${ }^{119}$ the client is better equipped to make decisions than the lawyer. In contrast, the lawyer is knowledgeable about the legal consequences of a particular course of action and is expert in probing client concerns so that the client confronts the full range of alternatives. ${ }^{120}$

For example, a criminal defense attorney might advise her client that if he goes to trial he will probably be found guilty and receive a sentence of incarceration, but if he pleads guilty he will be placed on probation. A trial, however, would give the client the opportunity to vindicate himself, a consequence that he might potentially value more than the downside risk that he will be convicted and sentenced to prison. Or the client may want to make a political statement by challenging the criminal justice system, rather than to adopt the posture of a supplicant who simply pleads guilty. If he is innocent, he may find it immoral to plead guilty, even in return for a more lenient sentence. Only the client can measure the tradeoffs between the choices of plea or trial and their respective consequences. ${ }^{121}$

Despite their focus on client decisionmaking, many client-centered advocates do not discuss the different kinds of decisions that clients might make in their cases or how the context of the decision might affect how authority is allocated between lawyers and clients. ${ }^{122}$ Their inattention to this issue stands in sharp contrast to

question of who is the better decisionmaker is irrelevant. It is the right of the individual to make her own choices that matters, however bad those choices might be. See People v. Stansbury, $17 \mathrm{Cal}$. Rptr. 2d 174, 183 (1993) (noting that the defendant asked whether his status as co-counsel with his lawyer would give him "the right to make any final decisions ... regardless of how foolish they may be," and indicating that the defendant had such a right), revd. on other grounds, 114 S. Ct. 1526 (1994).

117. See Mark Spiegel, Lawyering and Client Decisionmaking: Informed Consent and the Legal Profession, 128 U. PA. L. Rev. 41, $73-74$ (1979); Marcy Strauss, Toward a Revised Model of Attorney-Client Relationship: The Argument for Autonomy, 65 N.C. L. REv. 315, 332 (1987).

118. BINDER ET AL., supra note 27, at 5-9 (giving as examples economic, social, psychological, moral, political, and religious consequences); $i d$. at 17-18.

119. Id. at 10.

120. Id. at $13,20-21$.

121. For a discussion of the trade-offs clients make in assessing legal alternatives and their consequences, see id. at 11-13. See also Spiegel, supra note 117, at 100-01.

122. See John K. Morris, Power and Responsibility Among Lawyers and Clients: Comment on Ellmann's Lawyers and Clients, 34 UCLA L. REv. 781, 783-84, 795 (1987); Robert 
the vast volume of scholarly work that looks at the process of clientcentered counseling. These works run the gamut from defining client-centered counseling and comparing it to other models of lawyering, ${ }^{123}$ to exploring how the process can be improved to ensure that decisions are truly those of the client and not of the lawyer. ${ }^{124}$

Client-centered theory concedes that some decisions must be reserved for attorneys or the practice of law would become unworkable. Because legal representation requires a large number of decisions, lawyers do not have the time to discuss every decision with a client. ${ }^{125}$ This approach not only would take too many hours but would prevent an attorney from implementing many decisions because the time frame for some decisions, especially those in litigation, is too short to permit lawyer-client consultation. Thus, clients should concentrate their energy on the task of figuring out what they want to achieve through legal representation, and lawyers should implement those objectives.

With few exceptions, ${ }^{126}$ client-centered writers analyze the decisions facing the client in generic terms, without distinguishing the type of decision at stake. When they discuss the context of a decision specifically, the most active arena of client decisionmaking appears to be in the area of legal process, either in initiating legal procedures - by filing a lawsuit or an appeal or invoking an informal mechanism, for example - or in disposing of a case through

D. Dinerstein, Clinical Texts and Contexts, 39 UCLA L. Rev. 697, 703 (1992) (book review) (criticizing the client-centered model's lack of context). For a notable exception, see Spiegel, supra note 117.

123. See, e.g., Morris, supra note 122, at 809 (questioning whether the model reflects the actual practice of law); William H. Simon, Ethical Discretion in Lawyering, 101 HARv. L. REv. 1083 (1988) (finding the model inconsistent with moral lawyering); Abbe Smith, Rosie O'Neill Goes to Law School: The Clinical Education of the Sensitive New Age Public Defender, 28 HARv. C.R.-C.L. L. REv. 1, 27-37 (1993) (advocating a middle ground between a client-centered and a lawyer-centered approach); Dinerstein, supra note 26 (exploring the various arguments for and against client-centeredness).

124. See, e.g., Dinerstein, supra note 26 , at 556-70 (proposing that the model should permit greater flexibility in lawyers giving advice to clients who have not requested it); Ellmann, supra note 107, at 744-45 (noting that the model is paternalistic in denying advice to clients who want it); Dinerstein, supra note 122, at 709-11 (arguing that the model should be more contextual in outlining the appropriateness of lawyers sharing their opinions and values with clients).

125. BINDER ET AL., supra note 27, at 266.

126. See, e.g., Robert F. Cochran, Jr., Legal Representation and the Next Steps Toward Client Control: Attorney Malpractice for the Failure to Allow the Client to Control Negotiation and Pursue Alternatives to Litigation, 47 WASH. \& LEE L. Rev. 819, 853-76 (1990) (arguing that clients should control important decisions about negotiation); see also infra notes 159 , 164 and accompanying text. 
settlement or trial.127 This focus on process implies that other kinds of decisions are relegated to lawyers and thus are excluded from the lawyer-client dialogue. ${ }^{128}$

\section{Lessons for Case Theory}

Despite client-centered theorists' lack of attention to context, their critique of the traditional formulation of the allocation of decisionmaking authority articulated in the professional codes, ${ }^{129}$ and the client-centered response to this formulation, offers promise for involving clients in case theory discussions. Although the traditional standards do not speak directly to case theory, they do set out a framework for determining how decisionmaking is allocated between lawyers and clients.

Client-centered advocates assert that traditional standards articulated in the professional codes offer little guidance about which decisions clients should make ${ }^{130}$ and leave too many decisions in the hands of lawyers. ${ }^{131}$ One formulation of this traditional standard is set forth in the Model Rules: the client should make all decisions "concerning the objectives of representation," but need

127. BiNDER ET AL., supra note 27, at 135, 147-48 (referring to a decision about whether to initiate or settle litigation as an "ultimate" or "basic" decision, not an "auxiliary" decision). While these choices may be "ultimate" to lawyers because they dictate the formal mechanisms lawyers pursue in their daily lives, they mean less to clients, who might frame these choices in different terms.

128. Client-centered lawyers may share more in common with traditional lawyers on the question of who should decide than they do on the decisionmaking process, which is a painfully laborious one that little resembles the traditional model. See Ellmann, supra note 107, at 720, 750-53 (discussing the Binder and Price model).

129. The relevant codes are the Model Rules of Professional Conduct, the Model Code of Professional Responsibility, and the state variations on these models. See Spiegel, supra note 117, at 65-67; Strauss, supra note 117, at $318 \mathrm{nn} .11,13$; Dinerstein, supra note 26, at 534-38. For the standards in criminal cases, see the ABA STANDARDS FOR CRIMINAL Justice 4-5.2 (3d ed. 1993) ("The Defense Function"). In addition, the Constitution may impose duties in criminal cases that exceed those imposed by the ethical rules. See Jones v. Barnes, 463 U.S. $745,751,753$ n.6 (1983) (constitutionalizing the right of the defendant to decide whether to plead guilty, waive a jury, testify, or appeal); Ogletree \& Hertz, supra note 96, at 35-36 (noting the heightened scrutiny of conflict rules under the Sixth Amendment's requirement of effective assistance of counsel).

130. Although scholars disagree about whether the Model Rules or the Model Code provide a greater role for the client, compare Ellmann, supra note 107, at 717 \& n.2 (asserting that the Model Code gives clients a greater role) with Mark Spiegel, The New Model Rules of Professional Conduct: Lawyer-Client Decision Making and the Role of Rules in Structuring the Lawyer-Client Dialogue, 1980 AM. B. Found. REs. J. 1003, 1005-07, 1015 (claiming that the Model Rules provide for more client control), they agree that neither offers much in the way of defining the parameters of required client participation, see Stephen Gillers, What We Talked About When We Talked About Ethics: A Critical View of the Model Rules, 46 OHio ST. L.J. 243, 253-54 (1985) (expressing the inadequacies of the Model Rules); Spiegel, supra note 117, at 65-67 (showing the ambiguities in the Model Code); see also Spiegel, supra.

131. BINDER ET AL., supra note 27 , at 271 (citing the ends-means standard as leaving too many decisions for the attorney); Strauss, supra note 117, at 317. 
merely be "consult[ed] . . . as to the means by which they are to be pursued." 132 Whether framed as a distinction between ends and means, ${ }^{133}$ substance and procedure, ${ }^{134}$ or merits and tactics, ${ }^{135}$ this standard creates a dichotomy between client goals and the attorney's plan for achieving those goals. ${ }^{136}$ Clients determine goals, while the implementation of those goals is relegated to their lawyers.

Proponents of client-centeredness identify several flaws in the ends-means dichotomy. The fluidity of the concept makes it nearly impossible to predict whether a client will view a particular decision as implicating means or ends. ${ }^{137}$ For example, if "winning" is the objective of most clients, then a decision not to win - to plead guilty - is an end and the decision belongs to the client. But if the client also has the objective of receiving a light sentence, then pleading guilty is a means to this end. ${ }^{138}$

Although this ambiguity could seemingly be resolved by the lawyer simply asking the client whether the decision implicates ends or means, ${ }^{139}$ the reality is that virtually every decision in a case is a mixed question of ends and means. But rather than assigning all decisions to clients, this standard instead has been interpreted to leave most decisions in the hands of lawyers, relegating only decisions such as settlement versus trial to clients. ${ }^{140}$ Attorneys often mistake ends for means because they can only conceive of a stock set of objectives, such as winning or escaping punishment. ${ }^{141}$ This

132. Model Rules of Professional Conduct Rule 1.2(a) (1993) (providing in addition that "[i]n a criminal case, the lawyer shall abide by the client's decision, after consultation with the lawyer, as to a plea to be entered, whether to waive jury trial and whether the client will testify").

133. See Strauss, supra note 117 , at 324 .

134. See Spiegel, supra note 130, at 1003-04 n.6.

135. See Binder ET AL, supra note 27, at 266 n.23 (interpreting Model Code EC-7-7 as incorporating a merits-tactics dichotomy).

136. Strauss, supra note 117 , at 324 (calling the division a "false" dichotomy).

137. BiNDER ET AL., supra note 27, at 267; Strauss, supra note 117, at 325 .

138. Strauss, supra note 117 , at 325 . As a matter of constitutional law, the decision about whether to plead guilty is reserved for the client. Jones v. Barnes, 463 U.S. 745 (1983).

139. For a discussion of the problems of consultation and waiver, see infra text accompanying note 154. Although these commentators make much of the difficulty of distinguishing objectives from means, see supra notes 137-38 and accompanying text, simply asking the client, "Is $\mathrm{x}$ an objective?" would seem to answer this question. The problem actually lies in devising a definition that will allow the attorney to decide in the abstract on which side of the line a particular decision falls so as to avoid the need to consult with the client about each and every decision that must be made in a case.

140. Strauss, supra note 117 , at 318.

141. David Luban, Paternalism and the Legal Profession, 1981 WIs. L. REv. 454,459 n.9 (arguing that lawyers fail to recognize that ends often implicate questions of strategy and tactics); William H. Simon, The Ideology of Advocacy: Procedural Justice and Professional 
limited view ignores what matters to some clients, who may care as much about the fairness of procedures as they do about the results obtained by their lawyers, ${ }^{142}$ or who may wish to be involved in strategy decisions. ${ }^{143}$

Indeed, the ends-means distinction is especially pernicious in the area of skills and strategy. ${ }^{144}$ On the one hand, the decision about whether to call a witness who is a close friend or family member may appear to be a tactical decision geared toward the client's ultimate objective of acquittal. On the other hand, the decision may also implicate the independent objective of saving the witness from the stress of testifying, ${ }^{145}$ especially about matters that might be devastating to his personal life. ${ }^{146}$ The client might prefer these objectives even if it means that he might lose.

The result, as client-centered theorists recognize, is that traditional standards leave clients out of discussions of strategy and

Ethics, 1978 Wis. L. REv. 29, 57 n.65, 58 (portraying the lawyer as an advocate with a set of ends distinct from her client's).

142. See BINDER ET AL, supra note 27, at 267 (providing an example in which a client has twin objectives of protecting her sister from testifying as a witness and avoiding conviction); John Thibaut \& Laurens Walker, Procedural Justice: A Psychological Analysis (1975); Jonathan D. Casper et al., Procedural Justice in Felony Cases, 22 LAw \& Socy. REv. 483 (1988) (analyzing how procedural fairness, as well as case outcome and distributive justice concerns, contribute to litigant satisfaction).

143. See Strauss, supra note 117, at 340 (arguing that an autonomy-based theory of client decisionmaking favors providing the client the opportunity to consent to strategic decisions).

144. I use the term strategy to mean the sum of tactics reflecting some overall plan to achieve a set of objectives. See CARLSON \& IMwINkELRIED, supra note 35, at 35-37; Richard K. Neumann, Jr., On Strategy, 59 FordHAM L. REv. 299, 300 (1990). The term lawyer skills means those activities that lawyers undertake on behalf of clients - such as witness examinations - rather than legal process decisions - such as whether to settle or go to trial. Although case theory touches on both strategy and skills, it is better understood as a mix of client goals and a concrete statement of what happened. See infra Part III.

145. BINDER ET AL., supra note 27 , at 267.

146. The classic example is provided by the hypothetical "Long Black Veil" case, based on the song written by M.J. Wilkin \& D. Dill. Strauss, supra note 117 , at $325 \mathrm{n} .50$. In that case, the client chooses not to assert an alibi defense because the alibi witness is his secret lover and married to his closest friend. Luban, supra note 141, at 456. 
skills ${ }^{147}$ - and, by analogy, case theory. ${ }^{148}$ Under one formulation of the traditional allocation of decisionmaking authority, "means are merely strategic decisions" 149 reserved for lawyers. Traditionalists justify this allocation of authority with reasons similar to those established for decisionmaking authority generally, but they also cite the greater need for technical legal expertise in strategy decisions and the foreshortened time for making these decisions in trial settings.

\section{Although little is known about the kinds of decisions lawyers typically examine with their clients, ${ }^{150}$ the actual practice of law ap-}

147. Ellmann, supra note 107, at 765 (stating that lawyers are granted "startling amounts of authority not only to advise but to decide on crucial questions of litigation strategy"). Numerous courts have held that the power to control strategy decisions rests with the attorney. See, e.g., Jones v. Barnes, 463 U.S. 745 (1983); United States v. Hearst, 466 F. Supp. 1068, 1087-88 (N.D. Cal. 1978); State v. Rodriguez, 612 P.2d 484, 489-90 (Ariz. 1980). But see Jones, 463 U.S. at 758-59 (Brennan, J., dissenting) (criticizing this result). As a constitutional matter, criminal defendants do not have the right to control the strategy and tactics in their cases, with the exception of the decision about whether to plead guilty, waive a jury trial, or testify. See Jones, 463 U.S. at 751. Moreover, the ABA Standards provide that defense counsel should make strategic and tactical decisions "after consultation with the client where feasible and appropriate." ABA STANDARDS FOR CRIMINAL JUSTICE, supra note 129, at 4-5.2(b).

148. Because the Supreme Court has held that defendants do not have the right to dictate issues for their lawyers to present on appeal, Jones, 463 U.S. at 751, it would appear that there is no constitutional right to control case theory at the trial level. Although one could argue that issues are less "legal" at the trial level and thus more appropriate for client involvement, see Lloyd Epstein, Informal Opinion, Champion, Nov. 1994, at 30 (arguing that ethical rules and the requirement of effective assistance of counsel mandate that criminal defendants have the right to select a case theory), the Court has not adopted this viewpoint. Even Justice Brennan, dissenting from the holding in Jones, would allow clients a lesser role in trial decisions than in appellate decisions. See 463 U.S. at 760. For a thoughtful critique of the Jones decision, see Vivian O. Berger, The Supreme Court and Defense Counsel: Old Roads, New Paths - A Dead End?, 86 Colum. L. Rev. 9, 28-49 (1986). See also infra note 164 and accompanying text (critiquing distinctions between decisionmaking in trial and appellate contexts). Some state courts, following Faretta v. California, 422 U.S. 806 (1975), have held that a defendant can veto his lawyer's choice of the insanity defense. See, e.g., Jacobs v. Commonwealth, 870 S.W.2d 412 (Ky. 1994); Treece v. State, 547 A.2d 1054 (Md. 1988); State v. Jones, 664 P.2d 1216 (Wash. 1983).

149. See Strauss, supra note 117 , at 324 (criticizing this formulation).

150. See supra note 27 (discussing the lack of empirical evidence about lawyer-client relations). The bulk of the empirical studies focus on unrepresented clients, see, e.g., William M. O'Barr \& John M. Conley, Lay Expectations of the Civil Justice System, 22 LAw \& Socy. REv. 137 (1988) (discussing a study of small-claims plaintiffs), or look at the relationship of represented clients to the court system, see, e.g., Tom R. Tyler, The Role of Perceived Injustice in Defendants' Evaluations of Their Courtroom Experience, 18 LAw \& Socy. REv. 51 (1984) (discussing a study of traffic and misdemeanor defendants). The latter studies miss important opportunities to address issues of the allocation of control between lawyers and clients. They ask questions such as "How much control did you have over the way in which the evidence in your case was presented?," but they analyze the answers as data about relative allocation of control between the client and the judge. Id. at 62,68 ; see also Jonathan D. Casper, Having Their Day in Court: Defendant Evaluations of the Fairness of Their Treatment, 12 LAw \& Socy. REv. 237, 248 (1978) (failing to distinguish whether criminal defendants' opportunities to tell their stories are restricted by their lawyers or by the court). Those studies that look at the question of client control often refiect little sophistication about decisionmaking issues, reducing a complex inquiry to questions such as "Did your lawyer listen to what you wanted 
pears to reflect the lawyer-dominated approach to strategy and skills as articulated in the professional codes. Several studies suggest that few lawyers explain strategic alternatives to their clients, let alone seek their consent before making decisions. ${ }^{151}$ Anecdotal evidence supports these observations. ${ }^{152}$ Still less is known about the quality of these discussions, although there is some evidence that lawyers who engage in strategy discussions with their clients dominate those discussions to the exclusion of their clients. ${ }^{153}$

Client-centered commentators have proposed several alternatives to the traditional formulation - alternatives that address the issue of what role clients might play in strategy and skills decisions generally and that raise the question of what role clients can play in case theory specifically. The first is the "waiver" approach, which allows each client to decide, after consultation with his lawyer, which choices require mutually participatory decisionmaking. Client-centered theorists view this solution as unsatisfactory because it is meaningful only to clients with enough information about the system to understand the array of available choices, and because the issue must be revisited often so that clients can revise their decisionmaking guidelines. ${ }^{154} \mathrm{~A}$ second approach that presumptively assigns all decisions to the client ${ }^{155}$ has the disadvantage of failing

to do?," see, e.g., Jonathan D. Casper et al., Procedural Justice in Felony Cases, 22 LAw \& Socy. REv. 483, 492, 505 (1988), and revealing little about the answers to such questions.

151. See, e.g., John P. Reed, The Lawyer-Client: A Managed Relationship?, ACAD. MGmT. J., Mar. 1969, at 67, 76-77 (discussing a survey of Florida Bar members); Jerome H. Skolnick, Social Control in the Adversary System, 11 J. Conflict Resol. 52, 65 (1967) (describing criminal defense attorneys as "players" on questions of strategy and tactics). But see BINDER ET AL, supra note 27, at 269 n.30 (discussing surveys of corporate lawyers, who report consulting with their large, corporate clients on a wide variety of matters).

152. See, e.g., Eleanor Randolph, 4 Guilty in Bombing of World Trade Center, Wash. Post, Mar. 5, 1994, at A1, A8 (reporting that the defense lawyer's case theory "triggered a strong negative reaction" from his client); Strauss, supra note 117, at 317,320 ; see also Epstein, supra note 148, at 30 (stating that "[m] ost criminal defense attorneys seem to believe that the choice of a theory of defense is theirs"). F. Lee Bailey advises criminal defense attorneys to tell their clients that the attorney "alone will control the strategy of the defense, decide what legal points are to be raised, determine what witnesses to call, engage in whatever discussions [he] deem[s] necessary with the prosecutor." F. LEE BAILEY \& HENRY B. Rothblatt, Fundamentals of Criminal Advocacy $\$ 58$ (1974). Apparently, Bailey practices what he preaches: with respect to one Mafia client who wanted to control his own defense, Bailey reports, "I told him that I'm an ex-Marine and that it wouldn't bother me to put a bullet between his eyes and eat spaghetti off his face." Stephanie Benson Goldberg, $O_{n}$ Trial in Foley Square, A.B.A. J., Jan. 1, 1988, at 42, 45. For a more general discussion of the problems facing criminal clients in sharing decisionmaking power on questions of strategy with their lawyers, see Berger, supra note 148, at 49-50.

153. Austin Sarat \& William L.F. Felstiner, Law and Social Relations: Vocabularies of Motive in Lawyer/Client Interaction, 22 LAw \& Socy. Rev. 737, 755-63 (1988).

154. See, e.g., BINDER ET AL., supra note 27, at 267; Spiegel, supra note 117 , at $82-83$ n.160, 84-85.

155. See Strauss, supra note 117 , at 340 . 
to distinguish between those decisions that seem to require greater lawyer expertise and intervention and those that do not.

In a third approach, client-centered advocates have proposed standards for determining which decisions belong to lawyers and which belong to clients. The best-known of these is the standard reserving decisions for clients whenever a lawyer "would or should know that a pending decision is likely to have a substantial legal or nonlegal impact on a client."156 The commentators, in applying this standard to litigation strategy decisions, also require that the impact be "beyond [that] normally associated with the use of professional skills and crafts."157 While this standard is preferable to the traditional formulation because it recognizes that clients can have important interests in matters that fall into the category of lawyer skills, such as whether to call a particular witness or how vigorously to defend a lawsuit, it offers surprisingly little guidance about clients and case theory.

\section{Critique - The Foray into Skills and Strategy}

Despite their insights into the flaws of the traditional model, client-centered theorists do not take case theory seriously. Even the "substantial impact" standard, which suggests fairly broad client decisionmaking in the context of litigation strategy and skills, leaves the question of client involvement in case theory virtually unexplored. The proponents of this standard inherit an abstract and monochromatic terrain where references to case theory are few. ${ }^{158}$ The commentator who argues that clients should control how their stories are presented, including whether to waive an affirmative defense and which claims to argue to the trier of fact, stands alone in this bleak landscape. ${ }^{159}$ The client-centered literature fails to present even a single example in which a lawyer sits down with a client and walks through alternative case theories and their implications for the case and the client. In this respect, the client-centered ap-

156. BINDER ET AL, supra note 27 , at 268 . The lawyer should make this determination by using "such skill, prudence, and diligence as other members of the profession commonly possess and exercise.'" Id. at 268 (quoting Budd v. Nixen, 491 P.2d 433, 436 (Cal. 1971)).

157. Id. at 271.

158. For example, Haydock and Sonsteng adopt the "substantial impact" standard, see HAYDOCK \& SONSTENG, supra note 42 , at 41 , but they make no mention of client involvement in selecting a case theory. While other examples, such as choices concerning aggressive litigation strategies, see BINDER ET AL., supra note 27, at 270-71, might on their face seem to refer to case theory, this is not what I mean by case theory. See infra Part III.

159. See Spiegel, supra note 117 , at 57-58, 66, 123-26. 
proach differs little from the traditional approach, which relegates virtually every decision about case theory to lawyers. ${ }^{160}$

Following in these footsteps, the proponents of the "substantial impact" standard discuss case theory in a single sentence and conclude that clients should have less control over this decision than, for example, over the decision about calling a witness. ${ }^{161}$ Although there may be differences in the perceived immediate impact on the client, it is not apparent why case theory development should rest in the hands of lawyers, while the decision to call a client's boss as a witness requires consultation. ${ }^{162}$

It may be that these commentators, like other client-centered theorists, recognize that clients should make important decisions, but misperceive the nature of decisions that go to the heart of a case. All strategy and tactics are not created equal. In the hierarchy of strategy decisions, case theory is the decision that drives virtually every other decision in a case.

In a very real sense, then, giving clients control over which witnesses to call gives them very little unless they are also delegated the decision about case theory. While a client might very well have reasons unrelated to case theory for calling or not calling a particular witness, ${ }^{163}$ this decision is also a strategic and tactical choice driven largely by case theory. To give clients input into only a part of this equation is to limit the real possibility of client involvement in their own cases.

Perhaps the reluctance to embrace client decisionmaking about case theory stems from a failure to understand the real differences in the degree to which strategy decisions can be the subject of collaboration between lawyers and clients. Indeed, many trial decisions must be made quickly and on the spot. But an understanding of the process of case theory development debunks the notion that all trial strategy must be left to lawyers because decisions must be made quickly without time for consultation. It is the nature of the decision, rather than the legal forum, that should determine the ap-

160. Compare Shalleck, supra note 10, at 1745-46 (arguing that in client-centered theory the lawyer "conceives and develops alternative case theories" and continues to "confine the client to the nonlegal world") with supra notes 100-06 and accompanying text (arguing that the traditional approach rejects client participation in developing case theory).

161. See BINDER ET AL., supra note 27, at 271. Although the authors use the term casein-chief, they seem to mean something similar to the concept of case theory, at least as it is framed in standard lawyering texts. See supra section I.A.

162. See Binder ET AL., supra note 27, at 271.

163. See id. at 267. 
propriateness of shared decisionmaking. ${ }^{164}$ Case theory is the quintessential question that can, and indeed should, be decided in advance of trial. It is precisely the kind of decision suited to brainstorming and collaboration with clients.

Client-centered theorists need to take the insight that the choices lawyers make create the official conception of what the case is about in the legal system ${ }^{165}$ one step further by truly integrating the client's perspective. Rather than seeing each case as a series of discrete choices, each segregable from the other - should I settle, go to trial, make this objection, or call this witness? - lawyers and theorists should instead view a case as a unified whole, bound together. This is the mistake that the traditionalists make in creating the ends-means dichotomy, a mistake that client-centered theorists quickly call them on. Ironically, client-centered theorists miss the opportunity that case theory offers - the opportunity to play out the futility of the distinction between ends and means. For some clients, case theory is a means to an end; for others, it may be an end in itself.

Moreover, even if the "substantial impact" standard is interpreted to comprehend decisionmaking about case theory, by imposing significant hurdles to client involvement it demonstrates some underlying discomfort with clients making these kinds of decisions.

First, a different standard is imposed for decisionmaking about strategy and skills than for other kinds of decisionmaking. For the client to make decisions about strategy and skills, the impact must be not merely "substantial" but "beyond th[at] normally associated with the use of professional skills and crafts."166 If the impact does not reach this level, the client is excluded from the decisionmaking picture.

This approach offers little guidance on how to distinguish the typical lawyering skill that calls for lawyer-dominated choices from the kind of skill that requires participatory decisionmaking. It either provides a laundry list of those skill decisions that seem to

164. Karen A. Krisher, Jones v. Barnes, the Sixth, and the Fourteenth Amendments: Whose Appeal Is It Anyway?, 47 OнIо ST. L.J. 179, 190-91 (1986) (distinguishing decisions in the appellate setting that can be made in advance from those that cannot). While a trial practice in general requires more spontaneity than an appellate practice, some trial choices can be made in advance. Epstein, supra note 148, at 31. By the same token, some appellate decisions must be made on the spot, such as responding to questions at oral argument. For a discussion of the constitutional dimensions of client decisionmaking in the context of criminal cases, see supra note 148 and accompanying text.

165. See Jones v. Barnes, 463 U.S. 745, 762 n.6 (1983) (Brennan, J., dissenting).

166. BINDER ET AL., supra note 27 , at 271. 
require client consultation, ${ }^{167}$ some of which seem virtually indistinguishable from those that do not, ${ }^{168}$ or leaves lawyers to guess on a case-by-case basis the impact of the exercise of their skills on particular clients. Although the standard on its face seems to create more room for client decisionmaking, client decisionmaking in this area is still the exception, rather than the rule.

Second, the decisionmaking process set out for deciding questions of lawyer skills is not very elaborate or demanding ${ }^{169}$ and appears to leave ultimate authority in the hands of lawyers. ${ }^{170}$ In contrast to legal process decisions, in which clients are the decisionmakers, here it seems lawyers need only consult with their clients when it comes to strategy questions. Because consultation and decisionmaking are two different concepts, ${ }^{171}$ the process is a far cry from the lawyer-client partnership envisioned by the theory.

Given that the context of the choice is critical, no standard could obviate the need for the lawyer to make discretionary decisions in particular cases about the scope of client decisionmaking in the murky arena of lawyering skills. Yet even the standard that seems to afford the broadest client involvement is so replete with caveats and qualifications that client participation is stifled. By assigning clients a role limited to regurgitating the facts and choosing between procedural modes, client-centered theory has not been carried to its full extent with respect to case theory, and even the most client-centered theorists do not include the client in a meaningful way.

\section{Critical Lawyering Theory: Whose Story Is It?}

The critical lawyers make a major contribution to the traditional understanding of case theory by involving clients in the choice of which story to tell and thus recognizing the importance of client life experience and strategic skills in this endeavor. ${ }^{172}$ Because many of

167. See, e.g., id. at 270-71 (listing calling the client's boss as a witness, phrasing a contingency clause in a purposely vague manner, removing an action from state to federal court, and pursuing an aggressive litigation strategy as decisions requiring client input).

168. Id. at 271 (noting that the development of a case-in-chief should be within the lawyer's sole discretion).

169. See id. at $271 \mathrm{n} .33$.

170. See id. at 266-71.

171. Model Rules of Professional Conduct Rule 1.2(a) (1993) (distinguishing between the client's right to decide the objectives of representation and the fact that the lawyer need only consult with the client regarding the means by which those objectives are to be achieved); Spiegel, supra note 117, at 49 n.30.

172. In offering an overview of an approach whose boundaries are far from clear, see supra note 11, I do not discuss every scholar who is associated with the movement or all of 
these theorists do not talk in terms of case theory, ${ }^{173} \mathrm{I}$ consider how their insights about the related concept of storytelling can be translated to case theory development.

\section{Theory of Critical Lawyering}

Critical theorists view lawyers as tellers of stories or narratives. ${ }^{174}$ In considering narrative, critical theorists differentiate between the stories that clients tell about their lives and those that lawyers tell about clients' lives in the courtroom. The content of client narratives is the fabric of the client's life, not just the client's version of "what happened."175 The traditionalists also see storytelling possibilities in different versions of "what happened," but in the eyes of critical theorists, the gap between legal narratives and client narratives in traditional lawyering practices is too wide. ${ }^{176}$

Critical theorists see legal narrative through the lens of power. ${ }^{177}$ In this picture of power, legal narrative is a battleground of competing lawyer and client narratives in which lawyer narra-

the contradictions within the movement. For excellent examples of such analyses in different contexts, see Dinerstein, supra note 26 (comparing different arguments advanced by advocates for the client-centered model), and Robert W. Gordon, Critical Legal Histories, 36 STAN. L. REV. 57 (1984) (comparing different schools of the critical legal studies movement).

173. For examples of theorists who stress the importance of client narrative but do not discuss case theory in a meaningful way, see Alfieri, supra note 23; Alfieri, Dialogic, supra note 12; Alfieri, Mrs. V., supra note 12; and Lucie E. White, To Learn and Teach: Lessons from Driefontein on Lawyering and Power, 1988 WIs. L. REv. 699 [hereinafter White, Driefontein]. For important exceptions, see LÓPEZ, supra note 3, at 60 (urging lawyers to work with clients to "formulate strategies and remedies in [their] categories and characterizations"); Cunningham, supra note 2, at 2467 (contrasting the client's theory of the case with the lawyer's theory); Cunningham, supra note 8, at 1362 (describing the use of a police report as the basis for developing a case theory); Peter Gabel \& Paul Harris, Building Power and Breaking Images: Critical Legal Theory and the Practice of Law, 11 N.Y.U. Rev. L. \& Soc. ChANGE 369, 392 n.37 (1982-83) (explaining that in the defense of a Latino political group on charges of trespass, obstructing the sidewalk, and resisting arrest, "specific facts must be carefully woven into the radical lawyer's overall theory of the case"); and Lucie E. White, Subordination, Rhetorical Survival Skills, and Sunday Shoes: Notes on the Hearing of Mrs. G., 38 BufF. L. Rev. 1, 29 n.94 (1990) (using the term legal theories) [hereinafter White, Mrs. G.].

174. See, e.g., López, supra note 3, at 39-44; Alfieri, supra note 23, at 2110, 2119, 2121. Critical theorists alternately use the term narrative to mean literally what was said, see White, Mrs. G., supra note 173, at $17 \mathrm{n.65}$, and to describe themes that can be used as building blocks for cases, see Alfieri, supra note 23, at 2111, 2130.

175. LOPEZ, supra note 3 , at 65 (describing client narratives as "giving an account of themselves and the lives they would lead"); Alfieri, supra note 23 , at 2132 (explaining that narratives "contain the power to illuminate the client's world").

176. See LoPEz, supra note 3, at 43-44 (explaining that it is a common mistake to value "professional lawyering" above "the practice of lay lawyering that constitutes so much of everyday life"); Alfieri, supra note 23, at 2139 (arguing for a "more collaborative advocacy strategy in which [the lawyer and the client] decide[] together what narratives to present").

177. See Shalleck, supra note 10 , at 1750 (recognizing the importance of power dynamics in theoretics literature); White, supra note 10, at 1501-03 (applying a new "meta-theory of power" to the theoretics of practice movement). 
tives always emerge victorious. ${ }^{178}$ Lawyers reject client stories as implausible unless they fit into lawyer-endorsed strategies in which legal doctrine predominates. ${ }^{179}$ They construct fixed, predictable, and unimaginative stories that exclude client experience. ${ }^{180}$ Lawyer narratives drown out the voices of client narratives, marginalizing and subordinating them. ${ }^{181}$

In seeking to bridge the gap between lawyer and client stories, critical theorists offer two competing visions of lawyering. In one vision, client stories should be victorious in the narrative contest. ${ }^{182}$ In these contests, critical lawyers see the client's story as the only story worth telling - as they worship pure, unadulterated client narratives over any form of lawyer narrative. Only by "speaking out" can clients reclaim their narratives, deviating from prepared testimony in depositions and hearings. ${ }^{183}$

In the other vision, client narratives inform, but do not overthrow, legal narrative. ${ }^{184}$ The lawyer translates the client's story so

178. See Alfieri, supra note 23, at 2119, 2121, 2123-24, 2128 (explaining how poverty lawyers' usurpation of their clients' narratives entrenches the clients' subordination and inferiority both in the lawyer-client relationship and in society as a whole); Alfieri, Mrs. V., stupra note 12, at 629-33 (describing the subordination of clients' voices in poverty lawyers' narratives and client resistance to this process).

179. LOPEZ, supra note 3, at 109-10 (describing a particular poverty lawyer's refusal to acknowledge the validity of a client's self-help efforts); Alfieri, supra note 23, at 2127-30 (describing the common practice of poverty lawyers of restricting client speech in legal aid offices, administrative hearings, and courthouses); see WiLliams, supra note 5, at 6 (asserting that "legal language flattens and confines in absolutes the complexity of meaning inherent in any given problem"); Clare Dalton, An Essay in the Deconstruction of Contract Doctrine, 94 YALE L.J. 997 (1985).

180. See, e.g., Alfieri, supra note 23, at 2123-24 (explaining that narratives are disassociated from client context); Alfieri, Mrs. V., supra note 12, at 625 (stating that narratives "restrict[], rather than open[], access to the world of the impoverished client").

181. Alfieri, supra note 23 , at 2127-30 (criticizing strategies that present images of client dependence); Patricia J. Williams, Alchemical Notes: Reconstructing Ideals from Deconstructed Rights, 22 HARv. C.R.-C.L. L. REv. 401, 419-20 (1987) (pointing out that law school teaches students "to clothe the victims of excessive power in utter, bereft naivete; to cast them as defenseless supplicants raising - pleading - defenses of duress, undue influence and fraud").

182. See Alfieri, supra note 23, at 2134-45 (providing specific examples of client contributions to legal narrative, while failing to provide examples of lawyer contributions).

183. Alfieri, supra note 23 , at 2109-10, 2114-18 (recounting specific first-person client narrative that constituted self-empowerment in the telling); Alfieri, Mrs. $V$., supra note 12, at 642-43 (describing a client's indignant outburst at a welfare hearing); White, Mrs. G., sitpra note 173, at 29-31, 46-48 (recounting the story of a client who departed from the script envisioned by her lawyer). Examples of "speaking out" can also be found in trial records. See, e.g., Robinson v. United States, 897 F.2d 903, 905 (7th Cir. 1990) (discussing a criminal defendant who was allowed to make part of his own closing argument because, in the defendant's words, "sometime[s] a person has to stand up for himself . . . [and] speak out for himself").

184. LOPEz, supra note 3, at 49-53 (emphasizing that both the client and the lawyer are crucial to developing legal narratives and strategies); White, Driefontein, supra note 173, at 
it can be heard and understood in the legal system. ${ }^{185}$ In both visions, the legal stories ultimately told present vivid images of clients and are enriched by client life experience.

Yet even when lawyers incorporate client stories in their storytelling, critical theorists see legal forums as ultimately inadequate to capture the full range of client stories. ${ }^{186}$ Thus, client stories must also be related both in lawyer-client interactions - when clients can be seen as teachers, not as students ${ }^{187}$ - and in interactions between clients. ${ }^{188}$ The informality of these settings makes it possible to tell the whole range of client stories, unhampered by the constraints legal rules and procedures impose on conveying the life experiences of clients in legal forums.

\section{Lessons for Case Theory}

At first glance, the critical theorists' exhortations about clients reclaiming their narratives and reworking them into legal stories are not easily translated into the concept of case theory. ${ }^{189}$ The term case theory is noticeably absent from critical writing; ${ }^{190}$ indeed,

763 (describing third-dimension lawyering modeled after Paulo Freire and consciousness raising).

185. Cunningham, supra note 2 , at $2465,2468,2482$ (recounting instances of and describing the role of the lawyer as an interpreter intermediary in the dialogue between clients and the court system); Cunningham, supra note 8, at 1300, 1331 (describing "the practice of law as a kind of translation" in which the lawyer helps the client to be understood by adding her own voice to that of the client); see also LOPEZ, supra note 3, at 43-44; Lucie E. White, Goldberg v. Kelly on the Paradox of Lawyering for the Poor, 56 BRooK. L. Rev. 861, 862 (1990).

186. See, e.g., Lucie E. White, Mobilization on the Margins of the Lawsuit: Making Space for Clients to Speak, 16 N.Y.U. Rev. L. \& Soc. Change 535, 545-46 (1987); White, supra note 185 , at 861 (explaining that the process of advocacy inherently subordinates the client).

187. LóPEZ, supra note 3, at 37; Alfieri, supra note 23, at 2132; Cunningham, supra note 8 , at 1382.

188. Alfieri, Dialogic, supra note 12, at 692-95 (arguing that client empowerment requires not only lawyer-client dialogue but also dialogue between clients and community groups).

189. Although I include the work of Gerald López to inform the discussion of lawyer and client narratives in section I.C.1, I do not include him in my critique of the critical theorists. Much of Lopez's work concerns lawyer-client collaboration around storytelling. See, e.g., López, supra note 3; Gerald P. Lopez, Lay Lawyering, 32 UCLA L. REv. 1, 5-6 (1984) (discussing the importance of stock stories in legal argument); Gerald P. López, Reconceiving Civil Rights Practice: Seven Weeks in the Life of a Rebellious Collaboration, 77 GEo. L.J. 1603 (1989); Gerald P. Lopez, The Work We Know So Little About, 42 StAN. L. Rev. 1, 10 (1989) (noting the gap between lawyer understanding of the meaning of client stories and the client's actual meaning). Although Lopez's work in this area has greatly influenced the critical writers, their vision of practice differs from his. See, e.g., Alfieri, supra note 3, at 1750 (responding to Lopez's "aspirational vision" with the comment, "I harbor little faith in the ability of progressive lawyers to redeem community in their individual and collective meetings with subordinated clients."). It is far from clear that López would locate himself within the theoretics movement.

190. See supra note 173. 
critical theorists would seem to see case theory as "law-talk" and thus to reject it as disempowering for clients. Although critical theorists do not make explicit the link between legal narrative and case theory, their idea of legal narrative provides several openings to see case theory as something more than legal doctrine.

In composing legal narratives, critical theorists distinguish what happened from the meaning of what happened and believe that by opening up the client's world, the meaning of what happened can be better understood. These narratives not only are stories about what happened but also are composed of themes about client lives. ${ }^{191}$ Client life experiences inform "what happened" and change the nature of the legal stories lawyers tell.

The stories of Mrs. G..$^{192}$ and the villagers of Driefontein, South Africa, ${ }^{193}$ provide positive examples of the critical theorists' important insights about how case theory can reflect images of clients and the role that clients can play in decisionmaking about case theory. Mrs. G. is a thirty-five year old black mother of five daughters in a rural North Carolina town. She receives Aid to Families with Dependent Children (AFDC) benefits to support her family. After her AFDC worker assured her that the $\$ 592$ she received as damages from an accident would not count against her benefits, she made several purchases, including shoes for her children. ${ }^{194}$ Two months later, she received an overpayment notice ordering her to repay AFDC benefits in an amount equal to the damage award.195 Mrs. G. asked Lucie White, a legal services lawyer, to represent her at the upcoming hearing. ${ }^{196}$

In a separate story, the black villagers of Driefontein faced the loss of their small farming community when the government announced its plan to relocate the villagers to remote resettlement camps. ${ }^{197}$ Because the apartheid statutes authorizing the practice - a central feature of the subordination of South African blacks -

191. Alfieri, supra note 23 , at 2111,2130 (contrasting client themes of dignity, caring, community, and rights with lawyer narratives of client dependence).

192. See White, Mrs. G., supra note 173.

193. See White, Driefontein, supra note 173.

194. White, Mrs. G., supra note 173, at 24 (noting purchases of sanitary napkins, frozen food, and dresses and shoes for her children, as well as payments on a furniture bill).

195. Id.

196. Id. at 23-24.

197. White, Driefontein, supra note 173 , at $712-15,720-23$. For a current account of the problems faced by Driefontein villagers after their successful fight against relocation, see Lynne Duke, S. Africa's Next Battleground: Land, WAsr. Post, Apr. 23, 1994, at A1 (noting that white landowners stepped up evictions of black labor tenants in the months preceding black majority rule). 
were legal, the villagers turned to strategies outside the legal system to fight the resettlement. 198

a. Choosing Which Story to Tell. In the first place, Mrs. G.'s story illustrates that the choice of which story to tell can belong to the client. In preparing for the AFDC hearing, White met with Mrs. G. to discuss the pros and cons of two possible case theories. The first was an estoppel story about the AFDC worker's erroneous advice concerning the cash payment. The second was a waiver story categorizing Mrs. G.'s purchases as "life necessities" that were necessary to avert a crisis. ${ }^{199}$

In the meeting, White framed the choice of theory as one for the client to make ${ }^{200}$ and explained that the two stories posed opposite risks. ${ }^{201}$ Strategically, the waiver story was more likely a winner, but Mrs. G. might find the estoppel story more satisfying to tell. The estoppel story created a better role for Mrs. G. on her terms, by placing her in the affirming role of a finger-pointer, but it also presented a risk of alienating the hearing officer. On the other hand, the waiver theory, by creating a more passive role for Mrs. G., met the hearing officer's terms but forced Mrs. G. to invite the hearing officer into the intimate details of her life and to seek approval for her lifestyle. White does not tell us which role Mrs. G. preferred - indeed, White may not have asked this question - or how Mrs. G. weighed the strategic value of the two theories against the roles they created for her. All we know is that in the meeting Mrs. G. chose to tell both stories, although at the hearing she told a story that deviated from both theories. ${ }^{202}$

b. Valuing Client Life Experience. The stories of Mrs. G. and Driefontein also demonstrate how client life experience can enrich case theory. The Driefontein villagers organized a committee to develop a plan for fighting their relocation. ${ }^{203}$ The committee real-

198. White, Driefontein, supra note 173 , at $712-13,727-29$.

199. White, Mrs. G., supra note 173, at 27.

200. White recognizes that she had deviated from conventional practice, questioning: "Why had I even raised the question of which story to tell? It was a tactical decision - not the kind of issue that clients were supposed to decide. Why hadn't I just told her to answer the questions that I chose to ask?" Id. at 29 (footnote omitted).

201. Id. at 28-29.

202. See infra text accompanying notes 214-15.

203. White, Driefontein, supra note 173, at $730-32$. The villagers recruited a lawyer and an organizer to assist them. Id. at 723-24. Although they met with the lawyer every few weeks, the villagers were the architects of the negotiation strategy. See infra notes 244-45 and accompanying text. The organizer assisted on a number of fronts, including helping the women of the village establish a support group of residents from other threatened communities. Id. at 725, 727 . 
ized that its only option - short of violent resistance - was to negotiate with the government outside formal litigation, and they designed a negotiation strategy that ultimately defeated the government. 204

Although no formal law governed these negotiations, both sides used a kind of case theory as the central organizing concept for their strategies. The government's theory was that resettlement was required because a dam being constructed would flood the area occupied by the village. ${ }^{205}$ This theory matched the government's newly announced public position, in response to public pressure, that removals would no longer be based on racial or ideological considerations. ${ }^{206}$ In relying on this theory, the government had essentially locked itself into one version of events. If other alternatives to removal would not interfere with the dam's construction, the government's theory would crumble.

The villagers chose not to challenge the dam story but instead countered by devising alternatives built around the underlying story. They knew the dam story was a pretext for an ideological removal and used this knowledge, coupled with their knowledge of their government and the growing outrage over the homelands policy, to their advantage. The villagers were not trained in the law, but they nonetheless understood the government's dilemma. They knew that the government would pay a high political price for the forced removal if the government changed its story. ${ }^{207}$

The villagers conceived of their case as a story about how the dam and the village could coexist and then investigated other alternatives to removal. When they learned that the dam would flood only a small portion of their land, they asked the government to give them an equivalent amount of government-owned land located nearby as compensation for the submerged land.208 Rather than providing an alternative case theory, the government stuck with the

204. Id. at $732,737$.

205. Id. at 721-22.

206. Id. at 734.

207. The antiapartheid movement, which had targeted removals as an especially offensive piece of apartheid policy, id. at 733, was growing in political strength inside the country, paralleled by an upsurge in opposition outside of the country. After the removal was announced, the international pressure against the government intensified through the efforts of foreign journalists and human rights advocates who visited the village and harshly criticized the government in their writings. Moreover, the government was embarrassed about the recent murder of a village activist who fought the removal, and it feared additional adverse publicity. Id. at 722 .

208. They also persuaded the chief minister of the homeland designated as their new home to oppose removal. Id. at 734-35. 
dam story but rejected the proposed land transfer because it was smaller than the land taken by the dam. ${ }^{209}$

At this point, the villagers had the government where they wanted it. They discovered a larger tract located near the village and acquired the land as a donation from the owner, a large corporation. ${ }^{210}$ At this juncture, the government abandoned its removal plan. ${ }^{211}$ The villagers' case theory had been successful.

Moreover, in a different context, the story of Driefontein also reveals the power of facts as understood by the party closest to them. In a memorable passage, White describes how the villagers started a collection of media accounts critical of the government's removal efforts. ${ }^{212}$ They kept the clippings at the home of the widow of a murdered village activist who had opposed the removal. All the villagers touched the clippings and talked about how readers in other countries were connected to the village through these accounts. ${ }^{213}$ This heartbreaking story of community transcends any effort to give it meaning; in a sense, these "facts" are the theory.

In the story of Mrs. G., the client's understanding of her environment may have helped her construct case theory by revealing new dimensions of the "life necessities" theory. At the hearing, Mrs. G. testified that the shoes she bought for her daughters were Sunday shoes. She said that her daughters already owned shoes for school and needed nice shoes for church.214

Lucie White, Mrs. G.'s lawyer, was taken by surprise by this turn of events, because in preparing for the hearing, Mrs. G. told White that she had purchased school shoes for her daughters. Putting aside the unanswerable question of which kind of shoes Mrs. G. actually purchased with the overpayment, ${ }^{215}$ Mrs. G.'s actions suggest several important insights about case theory. At a purely doctrinal level, Mrs. G. may have understood that Sunday shoes fit the

209. Id. at 735 .

210. Id. at $735-36$.

211. Id. at 736 .

212. Id. at 727.

213. Id.; see supra note 207 (describing a recent murder).

214. White, Mrs. G., supra note 173, at 31 .

215. In telling the story, White seems to assume that Mrs. G. had in fact purchased Sunday shoes, not school shoes. Id. at $47 \mathrm{n} .151$. Viewed in this light, Mrs. G.'s imaginative use of the shoes should not be understood as raising issues of client perjury in creating case theory, as in the Anatomy of a Murder scenario. Even if it did, White was not in a position to know which kind of shoes Mrs. G. purchased, or to frame a response in light of this inevitable ambiguity. Mrs. G. also "forgot" about the conversation with the welfare worker that formed the basis of the estoppel theory. 
conventional meaning of the legal category "life necessities."216 To a black woman living in the southern Bible Belt - and to her white counterparts - Sunday shoes were not an extravagance but a basic human need. Her spirituality was an expression of a shared cultural identity, reflected in communal rather than individual worship, and an important part of her life. In her life, Sunday shoes were as necessary as school shoes.

White also offers a second, less conventional interpretation of Mrs. G.'s actions. Rather than accepting doctrinal constraints, she instead expanded the conventional meaning of the legal category to include Sunday shoes. In this way, she used the Sunday shoes to push the apparent limits of doctrine and enriched the doctrine with her life experience. ${ }^{217}$

As with the villagers' use of the newspaper clippings, Mrs. G.'s actions are also subject to another interpretation in which the reference point for case theory is not legal doctrine but instead facts apart from doctrine. Whatever her legal understanding of terms such as life necessities or estoppel, Mrs. G. understood how the Sunday shoes could influence the decisionmakers. She knew the worlds of the hearing officer, the county welfare director, and the welfare worker in some ways better than her lawyer did, and she understood the empathy invoked by an image of a black welfare mother purchasing Sunday shoes for her children. Not only did case theory create a context for the "fact" of the Sunday shoes, but the fact of the Sunday shoes was also powerful in its own right. 218

Similarly, in "forgetting" the estoppel story, Mrs. G. may have recognized the destructive potential of the facts necessary for this theory, whatever the legal merit of the argument. The facts blaming the welfare worker would pit the county and the welfare worker against Mrs. G., with Mrs. G. the inevitable loser. Or, on an even more subtle level, the hearing officer might look at the two women, see two black women, and either refuse to hold the AFDC worker responsible for her actions or refuse to make Mrs. G. the beneficiary of her worker's negligence. In short, Mrs. G.'s criticisms of her welfare worker would come full circle back to her, and the "facts" would have undermined a legally viable argument.

216. Id. at 47-48.

217. Id. at 47-51. Mrs. G. "ignored the doctrinal pigeonholes that would fragment her voice," id. at 48, "stretched the category of 'life necessity' to express her own values, and turned it around to critique [welfare's] systemic disregard of her own point of view." Id, at 49-50.

218. White chose not to argue the "life necessities" point in her closing, believing that her "lawyer's language couldn't add anything to what [Mrs. G.] had said." Id. at 31. 
c. Strategizing About Case Theory. Both stories also speak to the role clients can play at the intersection of case theory and strategy. Clients may add a strategy dimension that is at times inaccessible to lawyers. Clients may be more free to brainstorm new strategies than lawyers, who, like members of any other profession, learn specific modes of thinking that can hamper their creativity. ${ }^{219}$

The Driefontein villagers were wily legal strategists who had "figured out how to manipulate the system before the lawyer gave these skills a name."220 Although a cynic might say that they were successful only because the remedies lay outside the legal system, the circumstances they faced were as complex and shifting as those in any litigation context. They had to balance political forces both inside and outside the country, master technical data about the impact of the dam, and gauge the impact of all these factors on the interests of their opponents. 221

Similarly, the story of Mrs. G. can be interpreted as a triumphant tale about a superb case-theory strategist who made sophisticated judgments about alternative case theories after assessing these theories from three different perspectives: winning the hearing, protecting her relationship with the welfare system, and satisfying personal goals unrelated to these more instrumental concerns. ${ }^{222}$ While the first consideration matches concerns of both traditionalist and client-centered theorists, the other two propose new dimensions of case theory.

How might Mrs. G. think about the choice of case theory from these perspectives? ${ }^{223}$ If Mrs. G.'s goal were simply to win her case, she would, like the traditionalists, choose the theory most likely to appeal to the hearing officer, although she would bring her insights about the Sunday shoes and life experience to bear on this ques-

219. See White, Driefontein, supra note 173 , at 765.

220. Id. at 738.

221. As White eloquently puts it, "[t]hey gained power only by creatively reading the contradictions facing the government and orchestrating events so that the government would be constrained by its own previous positions." Id. at 736 n.147.

222. White suggests that Mrs. G. might have been the "better legal strategist of the lawyer-client pair," White, Mrs. G., supra note 173, at 47, although she also suggests that her victory was "more attributable to the mysteries of human character than to the rule of law." Id. at 52. For White, strategy is more than "the manipulation of legal doctrine," id. at 47, although she offers no clarifying definition.

223. For the last several years, I, along with my clinical colleagues at The American University and at Columbus School of Law, The Catholic University of America, have used this story in teaching case theory in our clinic seminars. We have found that the lesson about the client as strategist helps our students think about the role clients can play in case theory development. At least one other clinical program assigns the piece, see Spinak, supra note 22 , at 24 , although its focus appears to be on client voice more generally. Id. at 24-26. 
tion. ${ }^{224}$ If she were concerned about her relationship with the welfare system, she would consider how the life necessities and estoppel theories would affect this relationship. The estoppel theory would be dangerous, not only because blaming her welfare worker might offend the hearing officer, but also because this action might anger her welfare worker. As a welfare recipient, Mrs. $\mathrm{G}$. was dependent on both her worker and the welfare system, and she understood the repercussions of challenging either the system or its representative.225

But Mrs. G. may have approached case theory from a standpoint unrelated to winning the hearing or protecting her relationship to the welfare system. Perhaps Mrs. G. rejected the estoppel theory because it would not feel good to her to criticize her welfare worker, a fellow black woman. Or perhaps she revised the "facts" to fit the life necessities theory because the Sunday shoes allowed her more dignity than the story about the school shoes. 226 If these were Mrs. G.'s goals, her actions were not strategic in the conventional sense. But speaking out, if for no other reason than to have a voice, can be as strategic as intricately plotting testimony to dovetail with relevant legal categories or remaining silent to keep a part of the story secret.227

\section{Critique - Metaphors of the Narrative Contest and the Lawyer as Translator}

When translated into case theory, however, the critical lawyers' approach to legal narrative has both theoretical and methodological shortcomings. Despite their focus on client storytelling, critical lawyers are ultimately pessimistic about the opportunities for clients to tell their stories. But a broader concept of case theory provides many opportunities for client stories, because case theory is only "law-talk" to the extent that it is law-driven. Ultimately, there is

224. For a discussion of the contribution of Mrs. G.'s life experience to this question, see supra notes 216-18 and accompanying text.

225. White, Mrs. G., supra note 173, at 32-36, 48.

226. Id. at 48 . For Mrs. G., dignity may have been an especially important concern in interactions with a black woman who had achieved more economic success than she had achieved and who might be disapproving. For a discussion of the irresolvable ambiguity concerning the nature of the shoes, see supra note 215.

227. Of course, in refusing to follow her script, Mrs. G. may have had no case theory in mind; she may have spoken as she did because she did not trust her lawyer, because she wanted to flout her, or simply because she forgot the script her lawyer had devised. Other commentators have documented similar client concerns. See, e.g., Spinak, supra note 22, at 1-2. 
more room for storytelling about clients in legal forums than critical lawyers contemplate.

Indeed, if client voices are to be heard and clients are to be empowered, the process of developing case theory is central to this task. Rather than seeing case theory as a bridge between client and lawyer stories, however, many critical theorists envision an inevitable narrative contest between lawyers and clients. ${ }^{228}$ Lawyer and client stories are always at war, even for those lawyers who are conscious of the power dynamics in the lawyer-client relationship, and so a choice must be made between two opposing stories. This contest metaphor misses the mark in several important respects.

Although the stories lawyers and clients tell often diverge, not all stories lawyers tell differ from their clients' stories. A single story may be told not because the lawyer story has displaced the client story but because the stories are the same.

Even when lawyer and client stories diverge and lawyer stories predominate, this cannot always be explained by the exercise of power. Not all clients want to tell their stories. A client might choose silence or a lawyer narrative over her own narrative to improve her chances of winning or to achieve some other goal. This choice is marginalized in the critical world. ${ }^{229}$

Critical lawyers proffer a naive vision of clients, all of whom are pure of heart and eager to speak. But not all client stories are empowering, nor are all clients empowered. Like most stories in life, client stories reveal a broad spectrum of human character, ranging from sordid histories of abuse and neglect by unresponsive or repressive systems to accounts of clients who are themselves victimizers. Yet critical lawyers mostly write stories about idealized clients, such as Deon Williams, a two-year-old child suffering from sicklecell anemia whom the state excluded from a nutrition program;230 Mrs. Celeste, a saintly woman struggling to support a large foster family for whom she could not receive food stamps;231 and Josephine V., an impoverished young mother who made every conceivable effort to obtain milk and diapers for her baby, only to experience frustration and delay at every turn. ${ }^{232}$

228. See supra notes $177-81$ and accompanying text. For a compelling critique of the limits of an analysis of lawyering limited to power, see White, supra note 10.

229. See, e.g., Alfieri, Mrs. V., supra note 12, at 625-27 (criticizing "instrumentalist logic"). For a discussion of different goals case theory might serve, see infra Part III.

230. See Alfieri, Dialogic, supra note 12, at 693.

231. See Alfieri, supra note 23 , at 2111, 2114-18.

232. See Alfieri, Mrs. V., supra note 12, at 637-43. 
These clients hold little power in the world, yet they never lose their cases. ${ }^{233}$ Although lawyers must revise client stories to make clients appear sympathetic even when they may be less than deserving, critical lawyers need never exercise this skill because their clients are almost perfect from the start. The critical analysis, in recognizing only clients that make the job of lawyering easy, provides little frame of reference for client stories that are neither noble nor empowering.

While those relying on the translation metaphor seem to reject the notion of a narrative contest and to envision lawyers and clients collaborating about case theory, their vision of this collaboration is limited. Translationists wisely caution against lawyers viewing cases - and case theory - in purely doctrinal terms, ${ }^{234}$ but nonetheless tell stories that reveal a wide gap between lawyers and clients. In their world, a black client has the task of educating his lawyers that an encounter with the police can be viewed as a racial incident, when common sense suggests that race is quite likely an explanation for the encounter. ${ }^{235}$ They see differences in language as a key barrier to client empowerment, when in many instances the problem is simply bad lawyering, not problems of translation. ${ }^{236}$ The fact that they often fail to see the obvious in their own interactions

233. See, e.g., Alfieri, supra note 23, at $2114 \mathrm{n} .14$ (citing the invalidation of federal regulations that had authorized the reduction of the client's benefits); Alfieri, Mrs. V., supra note 12 , at $643 \mathrm{n} .128$ (referring to an ALJ's decision that the client was once again eligible for public assistance); Alfieri, Dialogic, supra note 12, at 693-94 (describing a New York court's finding that the two-year-old client was eligible for WIC benefits); White, Mrs. G., supra note 173, at 32 (referring to the State's finally withdrawing its claim of overpayment against Mrs. G.); White, Driefontein, supra note 173, at 699-700, 737 (citing the South African government's decision not to force the relocation of the villagers from Driefontein).

234. Cunningham, supra note 8 , at $1324,1361-68$ (recounting a case in which viewing the facts in Fourth Amendment terms ignored important parts of the narrative).

235. Cunningham, supra note 8 , at 1368-75. In this case, the client, a black man, was stopped in a white part of town in the middle of the night for an alleged traffic violation. Although the author makes much of the fact that viewing the case in Fourth Amendment terms forced a race-neutral overlay on the case, id. at 1370-71, it is difficult to see how the lawyers could have missed the point that race might have been involved in the stop.

236. For example, one author describes the case of a Spanish-speaking client in which his lawyers did not know if his insistence that he was "culpable" had the same meaning as legal guilt, Cunningham, supra note 2, at 2464-65, and the case of a client who rejected his lawyers' argument that prison officials failed to follow required procedures in favor of an argument that the entire prison disciplinary system was invalid, $i d$. at 2465-69. Although the author describes the problems of representation in these cases in terms of language differences, these cases reveal less a problem of translation than of inadequate counseling by the lawyers. In the first case, the lawyers did not probe with the client the meaning of guilt or the option of pleading not guilty even if he were guilty. Id. at 2483-84. In the second, the lawyers did not discuss with the client the pros and cons of the choice between the different case theories, or of the possibility of arguing both theories. Id. at 2492-93. Given the lawyering missteps revealed in some of these stories, many clients might choose instead to be represented by traditional lawyers. 
with clients, coupled with their own naivete about the judicial system, ${ }^{237}$ would seem to make an accurate translation almost impossible.

Translationists also proffer complex solutions to bridging the gap between lawyers and clients, relying on after-the-fact lengthy textual analysis of client stories. ${ }^{238}$ While these theorists are refreshingly self-critical, they overlook the fact that lawyer understanding must precede translation. Understanding begins with real listening to client stories. Once the lawyer has heard the story, understanding can be furthered by asking the client about the perspective she wishes to adopt in the case, and talking with the client about possible case theories. Through this exchange of lawyer and client experience, the lawyer can make client stories into case theory.

Perhaps the greatest weakness of these critical models is that they fail to recognize that legal storytelling, at its best, is more than either lawyer or client storytelling. Even when clients seize power in the relationship, actual collaboration is limited. ${ }^{239}$ The critical theorists view any client choice that cedes power to lawyers as manipulated, given the power imbalance in the relationship. Perhaps because of this power imbalance or the difficulty of translating across race, class, or other lines, the gap between lawyers and their clients appears insurmountable.

Yet collaboration can take many forms, ranging from the lawyer adopting the client's story by telling it in a legal forum, to lawyers and clients brainstorming case theory. As the story of Mrs. V. demonstrates, ${ }^{240}$ even the impact of powerful client stories can be

237. One author has expressed "shock" that a judge refused to follow established Fourth Amendment law in a particular case, and held instead that the police had the right to search a citizen without any reason to believe he was armed or dangerous. Cunningham, supra note 8, at 1320-22. Given the extent to which trial courts, especially lower-level criminal courts, routinely ignore the law, this judge's misapplication of the Fourth Amendment is hardly surprising, let alone shocking.

238. Cunningham, supra note 8 , at $1339-57$.

239. See Alfieri, supra note 23, at 2124-25; Cunningham, supra note 2, at 2466-68; Cunningham, supra note 8, at 1329-30. For an important exception, see LOPEZ, supra note 3, at $38-56$.

240. See Alfieri, Mrs. V., supra note 12, at 637-44. Criminal lawyers know that client stories are made invisible, and even incredible, if they are passed over by their lawyers. Although commentators disagree about whether the ethical rules allow defense lawyers to refer to perjured client testimony in closing argument, compare John Wesley Hall, Jr., Handling Client Perjury After Nix v. Whiteside: A Criminal Defense Lawyer's View, 42 MERcer L. REv. 769, 809-10 (1991) (arguing that lawyers cannot refer to client perjury in closing argument) with The Ethics Advisory Committee of NACDL Formal Opinion 92-2, reprinted in Ethics Advisory Opinion, ChAMPION, Mar. 1993, at 23, 27 (arguing that a lawyer should refer to client perjury in closing argument if the lawyer tried to stop the perjury and failed), omitting the client's testimony would signal that the client is not to be believed, id. at 27 . 
muted if the lawyer does not collaborate with the client or adopt the client's story. Mrs. V. spoke "out of turn" by interrupting the hearing officer to describe the indignities she had suffered at the hands of the welfare system, a story her lawyer had not told. ${ }^{241}$ While her attorney may have seen the act of silencing as his speaking for Mrs. V. at the hearing, ${ }^{242}$ this characterization misperceives the true nature of silence. By excluding her story from his case theory, Mrs. V.'s attorney made her story less meaningful to the trier of fact, and even Mrs. V.'s courageous act of speaking for herself could not cure this silence. Sometimes it is not enough for clients to speak out alone.

Critical lawyers, by equating speaking out with power and remaining silent with the absence of power, oversimplify a complex dynamic. ${ }^{243}$ In the story of Driefontein, the lawyer spoke on behalf of the villagers in order to obtain the land they wanted, using his special skills to implement the strategy the villagers devised.244 The villagers were far from powerless in a setting in which the allocation of power was determined as much by who devised the strategy as by who did the talking. 245

Taken together, the emphasis on narrative contest and the privilege afforded client narratives means that lawyers are virtually invisible, and perhaps irrelevant, in the critical world. Critical lawyers practice at the furthest end of the spectrum from the traditional lawyers whose practices they most abhor. Yet in their noble effort to reclaim clients, these scholars lose sight of the lawyers, to the detriment of their clients. In this process, case theory disappears. The case is whatever the client chooses to talk about, untempered by critical reflection and analysis and uninformed by legal doctrine.

Not only is critical theory deficient in its vision of case theory, but it is difficult to translate its insights to the actual task of developing case theory. The discrete tasks of lawyering, such as interviewing, counseling, and case theory development, may vary

241. Alfieri, Mrs. V., supra note 12 , at $642-43$.

242. Id. at 642-45.

243. As Jane Spinak perceptively notes, it is not voice alone that should be extolled but rather "voice understood and respected within the legal system, particularly by the lawyer." Spinak, supra note 22, at 26.

244. White, Driefontein, supra note 173, at $736 \mathrm{n} .147$ (noting that "[o]nly in the context of [the villagers'] overall strategy was [the lawyer's] connection of any value").

245. The same issues of power and control are reflected in clinical teaching, where clinical teachers are hardly silent despite the fact that their students do most of the talking in court. See Shalleck, supra note 14, at 113-36, 178-81. 
tremendously in their potential for broader client involvement, yet the actual tasks undertaken by lawyers are discussed only in broad conclusory terms. For example, Tony Alfieri, in lumping together his decisions to exclude a client from strategy discussions and to withhold from her his case theory and documents supporting this theory, ${ }^{246}$ fails to recognize the world of difference between giving a client documents that bolster a particular case theory and discussing with her the pros and cons of alternative theories.

Exhortations about client voice lack meaning unless they inform the actual dialogue between lawyers and clients and the work lawyers actually do. ${ }^{247}$ The actual exchange between lawyers and clients in critical theory articles is almost completely invisible, revealing only bits and pieces of their conversations. ${ }^{248}$ When these conversations do receive attention, they are often parodies of lawyer-client interactions, ${ }^{249}$ and the suggestions for improvement are either prosaic ${ }^{250}$ or eccentric. ${ }^{251}$ Often the observations of critical lawyers end abruptly with a self-critique, leaving us with only tantalizing teasers. ${ }^{252}$

At their best, critical lawyers offer a much-needed critique of traditional practices, some of which apply to case theory. Yet they do not carry their insights to an explicit discussion of lawyer-client collaboration around case theory. They avoid the hard question of how case theory can serve as a vehicle for bringing together the often very different perspectives of lawyers and clients to make an effective case. Missing is a vision of what clients might speak about and how lawyers might best serve as partners in that enterprise.

\section{The CASE}

Our client, Mr. Jay, ${ }^{253}$ was referred to the Criminal Justice Clinic, where I teach, by a local public defender's office. Jay is a

246. See Alfieri, supra note 23 , at 2128.

247. Dinerstein, supra note 10, at 981-89.

248. See, e.g., Alfieri, Mrs. V., supra note 12, at 636 (providing no details about "onesided and unilateral" lawyer conversation).

249. See, e.g., Alfieri, supra note 23 , at 2112-18 (describing an interview at which the client remains silent).

250. See, e.g., id. at 2139 (suggesting the possibility of counseling a client about whether litigation best serves her needs).

251. See, e.g., id. at 2136-37 (discussing the concept of lawyer-client "play"); Alfieri, Mrs. $V .$, supra note 12 , at $646-47$ (same).

252. See, e.g., Alfieri, supra note 23 , at 2128,2139 (discussing the author's own failure to include the client in case theory and strategy discussions).

253. I have adopted fictitious names for Jay and all other participants and have changed some characteristics of the case in order to respect client confidentiality. 
thirty-year-old black man who lives alone in southeast Washington, D.C. ${ }^{254} \mathrm{He}$ works as a janitor for a federal agency. ${ }^{255}$ Jay was charged with three misdemeanors: disorderly conduct, assault and battery, and resisting arrest. $256 \mathrm{He}$ had never been arrested for any other crime.

After he was convicted in a bench trial,257 Jay had filed a circuit court appeal and then had rejected a plea offer at the pretrial proceeding in the circuit court. Given the possibility of a jury trial, his de novo trial could be expected to take more time than the first trial $^{258}$ and would stretch the crowded docket of the overworked public defender. I accepted Jay's case and assigned it to a team of two students working under my supervision. ${ }^{259}$

In order to provide a solid foundation for discussing case theory, I will set out the "facts" of Jay's case as viewed from the multiple perspectives of Jay and the other participants. ${ }^{260}$ Because Jay ulticity.

254. The southeast quadrant of Washington, D.C. is the most impoverished section of the

255. Jay was fired from his previous job as a janitor because the numerous court appearances required in this case caused him to miss too much work.

256. Disorderly conduct is a statutory misdemeanor. See MD. ANN. CodE art. 27, $\$ 123$ (1992). Assault and battery and resisting arrest are common law misdemeanors. DAVID E. Aaronson, Maryland Criminal JuRY Instructions AND COMmentary $\$ \S 4.12,4.80$ (2d ed. 1988). The charges were contained in a statement of charges, which is one means by which an individual may be charged with a crime in Maryland. MD. R. 4-201. The statement was supported by an application for statement of charges, which is a narrative of the facts supporting the charges. The complainant signs both documents under oath before a judicial officer known as a commissioner.

257. Jay was tried in Maryland's unusual two-tier court system, under which all misdemeanors and a few felonies are within the jurisdiction of the district court, MD. CODE ANN., CTs. \& JuD. Proc. § 4-301(b) (1)-(2) (1989), in which jury trials are not available, MD. Code ANN., CTs. \& Jud. Proc. § 4-302(e) (1989). If the defendant is found guilty following either a guilty plea or a bench trial, he can appeal to the circuit court and is entitled to a trial de novo by jury. MD. Code ANN., CTs. \& Jud. Proc. § 12-401 (1989). For an interesting discussion of how a two-tier system disadvantages criminal defendants, see David A. Harris, Justice Rationed in the Pursuit of Efficiency: De Novo Trials in the Criminal Courts, 24 ConN. L. Rev. 381 (1992).

258. Jay was represented by an assistant public defender in the District Court trial, in which he was acquitted of a second count of assault and battery. See infra note 264 . The trial carried over to a second day and involved the testimony of seven witnesses.

259. The Criminal Justice Clinic represents individuals charged with misdemeanors and some felonies - who have met the income qualifications of the public defender's office. We accept cases set for trial during the school semester that will provide valuable pedagogical lessons. For insightful discussions of clinic supervision theory and practice, see Phyllis Goldfarb, A Clinic Runs Through It, 1 Clinical L. Rev. 65 (1994); Gary Palm, Reconceptualizing Clinical Scholarship As Clinical Instruction, 1 CuINICAL L. REv. 127 (1994); Shalleck, supra note 14; and Kathleen Sullivan, Self-Disclosure, Separation, and Students: Intimacy in the Clinical Relationship, 27 IND. L. REv. 115 (1993).

260. The source of the stories is the participants' trial testimony, the statement of charges, the application for statement of charges, and the police report. In addition, Jay's story is based on conversations with his student attorneys documented in file memoranda and, in a few instances, my recollection. A written transcript of the trial testimony was prepared by 
mately pled guilty to disorderly conduct and resisting arrest in the circuit court, ${ }^{261}$ the only legal forum in which these stories were told was the district court trial.

\section{A. The Stories}

\section{Client's Story - Implying Racism}

On a weekday afternoon Jay was shopping at a clothing store in a predominantly white suburb of Washington, D.C. Although he often shopped at this store, on that particular day he was bargainhunting at the store's "Bash" sale. He purchased a pillow and washcloths and then shopped for a pair of jeans. Jay, who is six feet, three inches tall and weighs 260 pounds, was unable to find a pair of jeans in his size, so he decided to look for a sweater.

As Jay browsed in the sweater department on the second floor, he noticed that he was being watched by three security guards, Mr. Dirk, Ms. Deal, and Ms. Mormon. Mormon is a full-time security guard. Dirk and Deal are police officers who moonlight as security guards; because they wore store uniforms, Jay was unaware that they were police officers. Both Dirk and Deal carried guns. All three guards are white.

Jay was carrying his purchases in a bag bearing the store logo. A receipt was stapled to one corner of the bag, which was partially open because the pillow was sticking out of the top. Jay had asked for a larger bag, but none was available.

The guards followed Jay for five or ten minutes, looking down every time he looked at them. Jay approached Mormon, told her that he regularly shopped in the store, and asked her why she and her companions were following him. She denied following Jay, said she needed to "check something out," and made a telephone call on the store telephone. Jay angrily thought that Mormon was reporting him for shoplifting and rode the escalator to the first floor, planning to leave the store. He stopped at the bottom of the escalator because his "stubbornness wouldn't allow [him] to leave." Not far behind were the three security guards.

From about ten feet away, Dirk shouted, "Hey pal, what do you have in the bag?" Other shoppers and store employees were within hearing distance of this remark. Jay replied, "Well, what I have in

the clinic's administrative staff from the official tape recording of the trial. Unofficial Trial Transcript, Maryland v. Jay (on file with author) (source withheld to protect confidentiality).

261. Jay received a suspended sentence and six months of unsupervised probation, and the assault and battery charge was dropped. His decision to accept the plea is discussed further infra in section III.B. 
the bag is what I purchased, and if you're accusing me of stealing, those are some strong accusations and if you are, then I will sue the fucking store." Dirk said, "Fuck you," and called Jay a "punk," and both men exchanged more profanities. Then Jay said, "You know, if you weren't wearing that gun, I'd probably whoop your ass for the degrading things that you were saying to me."

Two or three managers arrived, including Rosenholtz, an older white man with gray hair, and Thompson, a tall black man who is slightly heavier than Jay. Speaking all at once, the three guards reported that Jay had threatened Dirk with the gun. When Rosenholtz asked Jay what he wanted, he asked for a refund. Thompson put his arm around Jay and walked with him to the service counter at the front of the store. Dirk and Deal followed.

At the service counter, Jay waited while Rosenholtz began processing the refund. Dirk and Deal stood near the counter. Jay dug in his pocket for some change, sorted the pennies from the nickels, dimes, and quarters, and tossed the pennies up in the air, saying, "[M]oney is no big issue to me. . . . That's why you're following me around because you think I can't afford to buy anything." Deal suddenly moved toward Jay, urging Dirk to arrest Jay for assault and battery. ${ }^{262}$ Jay, who was startled by Deal's charge, heard Dirk say something in a loud and boastful voice. Dirk pushed Jay's arm and told him he was under arrest, but he did not state that he was a police officer or show any identification. ${ }^{263}$ Jay escaped from Dirk by backing away from the counter and toward the front exit.

When Jay left the store, a police officer in the parking lot leapt from his motorcycle and grabbed Jay. Jay told the officer that he did not know why the security guards wanted to arrest him for assault and battery and did not understand what was happening to him. Five or six officers, responding to the guards' 911 call, joined in. As Jay struggled, ${ }^{264}$ one officer handcuffed one of his arms and held him by that arm, while the other officers grabbed him by the other arm and completed the handcuffing.

After Jay was handcuffed, Deal arrived in the parking lot, where she punched him three or four times, slapped him, dug her hands

262. All three security guards claim that Jay threw the pennies at Deal and that the pennies struck her. See infra section II.A.3.

263. The relevance of their status as police officers and of Jay's knowledge of their status to the resisting arrest charge is discussed infra at notes 283-86, 299-300 and accompanying text.

264. Jay was acquitted of the second count of assault and battery, which accused him of "striking [Dirk] in the chest, knocking him to the ground" in the parking lot. 
into his neck to grab a gold chain he was wearing, and pulled on the chain, choking him. She then ripped the chain off his neck.

Five or ten minutes passed before the police took Jay to the station and booked him. While Jay waited in the parking lot, Rosenholtz put a refund in Jay's pocket and apologized for the incident.

\section{Supporting Stories - Seeing Racism}

Perry Rodriguez, Darryl Prince, and Jimmy Williams, three other shoppers who observed Jay's encounter with the three guards, tell stories supporting Jay's view of his case. ${ }^{265}$ Rodriguez is Latino; Prince and Williams are black. Rodriguez works as an office clerk and shops at the store once or twice a week. On the day that Jay was arrested, Rodriguez was shopping at the store with his friend Prince, who works for a temporary employment agency and plans to study engineering at a community college. ${ }^{266}$ Williams was shopping with his wife and three children in the pantyhose section of the store. ${ }^{267}$ This chronology weaves together the stories told by all three men. They corroborate Jay's story with respect to several key details, ${ }^{268}$ including the fact that Jay had a receipt for his purchases, that he threw the coins up in the air rather than at Deal, that he did not hit Dirk or anyone else, and that Deal punched Jay after he was handcuffed. Perhaps more importantly, they viewed Dirk as the hostile aggressor and the entire incident as racially charged, explaining why the security guards stopped Jay in the first place and then escalated the incident until it was out of control.

Before Dirk and Mormon encountered Jay that day, they stopped Rodriguez on the second floor of the store, and Mormon told him that he was banned from the store because one of his friends had shoplifted. When Rodriguez denied this accusation, Dirk became aggressive. He said, "Well, she told you to leave," but Rodriguez refused to leave, saying, "If I'm not doing wrong, I shouldn't be thrown out of the store." Dirk moved "real close" to

265. After Jay was taken into custody, these men gave statements to a police officer, along with their names, addresses, and telephone numbers. The prosecutor, however, did not contact them. Rodriguez and Prince went to the police station to find out how to contact Jay, but the station staff refused to release this information. They waited several hours for Jay to be released and told him how to reach them if he needed them as witnesses. sister.

266. Both men live in the suburbs, Rodriguez with his aunt and Prince with his father and

267. Williams was recently employed as an office manager but was unemployed at the time of trial.

268. I use footnotes to distinguish the portions of their stories that differ in significant respects. 
Rodriguez and said, "You young punks, you know, you think you can always come in here and ... not ... follow directions." Then he said, "Boy, when I talk to you, you need to look me in my eye." Rodriguez told the guards to leave him alone and walked away. When Dirk followed, Rodriguez told him, "Hey, you can follow me all day."

Later, as Rodriguez and Prince rode the escalator to the first floor, they observed Dirk "hassling" Jay. ${ }^{269}$ At this point, Williams, who was standing near the staircase on the first floor, joined the scene. He did not pay much attention to the argument until he heard someone utter the word black. ${ }^{270}$ When Williams heard this, he turned and saw Jay "having some trouble" with Dirk. Jay asked Dirk, "Why [are] you embarrassing me? Why [are] you harassing me? I shop here all the time. . . . Is it because I'm black?" Dirk replied, "No, it's not because you're black." Jay responded, "Why then?" and Dirk said, "I don't give a damn."

During this exchange, which lasted about fifteen minutes, the shoppers and employees who gathered to watch "were able to hear the argument and talk." Dirk "kept on bashing, provocating, [and] irritating" Jay, while Thompson, who had just arrived, was "apologizing, begging[, and] cooling [him] down."

At some point, Thompson said, "Look, for god['s] sake, come on[;] he hasn't done anything. We gotta let this guy go. ..." As Jay walked with the managers to the service counter, Rodriguez, Prince, and Williams watched from a distance. While Jay waited for his refund, Deal stood behind Dirk about two feet away. Dirk taunted Jay, saying "he could arrest him; that he wasn't scared of him [just] 'cause he was a big boy." Jay turned from the counter, reached into his pocket, and tossed some coins "straight up" in the air. ${ }^{271}$ Next, Deal "charged" towards Jay and accused him of throwing coins at her. To Williams, it looked like a "set up," so he shouted at Deal, "You lie. You are a liar." Then Dirk and Deal grabbed Jay, "roughhandling" him and pushing him out the front door. Jay cried out, "Leave me alone, what have I done? What are you trying to do?"

269. As Rodriguez and Prince described it, Dirk was "all up in [Jay's] face," Jay was upset, and both men were yelling.

270. At trial, Williams testified, "[Be]cause I'm black, I wanted to know, so I turned around, and was watching, was listening" to find out if the encounter was racially motivated.

271. The three men disagree about whether the coins struck Deal. According to Rodriguez, some of the coins struck Deal, who faced Jay when Dirk moved aside. Williams testified that the coins never touched Deal, and Prince did not see where the coins fell. 
Williams left his family in the store and went outside, where Rodriguez and Prince also observed the struggle in the parking lot. At some point during the struggle, Dirk slipped and fell. As the officers were "dragging" Jay on the ground, he pleaded, "Leave me alone, what have I done? Come on, don't do this to me." A store customer, a black woman, approached Deal after she hit Jay and said, "Why did you do that? You don't hit people!" In a nasty tone, Deal replied, "I don't care."

Later, Rodriguez called Rosenholtz, who apologized to Rodriguez for how he was treated in the store.

\section{State's Story - Denying Racism}

The State's story is told by security guards Dirk, Deal, and Mormon. ${ }^{272}$ In addition to wanting to convict Jay, the State wants to limit its exposure for any claims he might file against it for the actions of Officers Dirk and Deal.273 Identifying this story as the "State's story" sets it apart from the stories that other institutions, such as the store, might tell. ${ }^{274}$

Mormon, who is five feet, five inches tall, was working security with Dirk and Deal on the second floor of the store on the day that Jay was arrested. Deal is five feet, one inch tall and weighs 110 pounds; Dirk is of medium build.

Before the Jay incident, the guards had a "run-in" with Rodriguez, whom Mormon recognized as someone Rosenholtz had argued with and banned from the store. Mormon confronted Rodriguez with this fact and then walked over to a telephone to request a manager to come upstairs.

While Mormon stood at the telephone, she noticed Jay carrying a store bag with a receipt stapled to the outside. The bag was partially open and a pillow was sticking out of it. The store has a policy

272. Dirk and Mormon testified as witnesses for the State at trial, while Deal wrote and signed the statement of charges and the application for a statement of charges and authored the police report. To avoid telling three versions of the story, I present the story that appears here as a composite. I use footnotes to distinguish points where the perceptions of the guards vary in ways that matter to case theory. While Thompson testified for the State, the label State's story is a misnomer because his testimony supports our client's story in part. Thus, I set out his story separately infra in section II.A.4.

273. If Dirk and Deal were acting in their capacity as police officers, Jay could assert a cause of action against the State under state law for the torts of assault and battery, false arrest, and false imprisonment. The same facts would give rise to constitutional torts under 42 U.S.C. § 1983 (1988). See Pitchell v. Callan, 13 F.3d 545 (2d Cir. 1994).

274. Although the store may share the State's concern about civil liability, it may be either more or less enthusiastic about prosecuting Jay. The store might want Jay convicted to obtain an order prohibiting him from shopping at the store or, contrarily, might support Jay out of a concern about negative publicity or a belief that Jay was unjustly treated. 
that merchandise must be verified for any shopper carrying a bag that is not stapled shut. Mormon nodded to Deal to alert her; Deal nodded back.

When Jay noticed that the security guards looked at him and made eye contact, he approached Mormon, stood four inches from her face and said in an agitated tone, "I dare . . . any of you racist officers to check my fucking bag or stop me on the way out of the store, 'cause I'll sue the store." Mormon walked over to Deal, who was joined by Dirk, ${ }^{275}$ and told them about Jay's dare. Dirk was carrying a loaded nine-millimeter automatic weapon, and Deal also carried a gun.

Jay left and went down the escalator, while Dirk and Mormon pursued him, trying to look at his bag. Meanwhile, Deal called downstairs to alert someone at the front desk to stop Jay. On the escalator, Mormon pointed to Jay. When Dirk looked at him, Jay stared back and said, "What the fuck are you looking at?"

At some point, Mormon tried to calm Jay down by explaining the store's policy and telling him she was just doing her job and that he could see the manager if he had a problem with the policy. When Jay replied that he believed she wanted to see his bag because he was black, Mormon told him that she was involved in an interracial marriage.

At the bottom of the escalator, Jay walked past Dirk carrying a bag under his arm "as if to hide" the bag from Dirk. Jay retraced his steps, stood less than three feet from Dirk, and said, "Touch my fucking bag and I'll sue this fucking store." Dirk replied, "[S]ir, it's the policy of [the store] that all bags be securely stapled shut," and told Jay that he would have to comply with the policy to remain in the store. Jay said, "You don't know what the fuck to do, and you just blew your chance." Dirk replied, "I know exactly what to do[.] I'll call the manager over and he can discuss it with you."

At this point, Jay became loud and angry, and a crowd began to gather. Jay yelled, "The only reason you are harassing me is because I'm black." When Dirk didn't respond, Jay pointed his finger in Dirk's face and said, "I am gonna take that pea shooter off your hip and pistol whip you with it."276 Dirk was afraid to move and asked Deal to call for backup.

275. Dirk testified that he was summoned to the second floor for "an altercation" with Jay, was "advised" that Jay had an open store bag with a pillow sticking out of it, and was asked to follow "the subject" downstairs.

276. Mormon testified that Jay dared Dirk to check his bag and threatened to "take [Dirk's] pea shooter off and whoop his ass with it." 
Dirk then pointed his finger at Jay, who said, "Get [your] finger out of [my] face." Jay then threatened to take Dirk's gun from him and shoot him. Dirk, raising his voice for the first time, asked Jay if he was threatening him.

At this point, Thompson and Rosenholtz joined the fray, repeatedly tried to calm Jay down, and told him that he could receive a refund. Thompson pushed Jay to the front of the store, using his "body as a block" between Jay and Dirk. Jay twice tried to "leap over" Thompson to get at Dirk, shouting, "[T]ake your fucking eyes off me."

While Jay waited for his refund, he "walked back and forth like a caged animal," screaming about discrimination and acting "out of control." Finally, Jay "turned on" Deal, who was standing at the front door waiting for backup. Dirk moved next to Deal to protect her and asked a store clerk to call 911 to request a faster response.

Then Jay took some change from his pocket and picked out six or seven pennies. He said, "I make more fucking money than you'll ever see[;] here, you want some?" and threw the change in Deal's face. Deal "jerked back" against a railing when the change struck her, and cried out, "Assault and battery!" Dirk grabbed Jay's arm, announced that he was a police officer, and told Jay he was under arrest. Jay lunged back, told Dirk to get his hands off of him, and pushed Dirk's arm away. When Dirk grabbed Jay by the arm again, he broke free and ran out of the front of the store.

The guards noted Prince and Rodriguez among the crowd gathered at the front door and observed them complaining to a manager about the "racial thing" involving their own mistreatment by the guards.

Dirk pursued Jay into the parking lot, followed by the crowd. A police officer leapt from his motorcycle and grabbed Jay by one arm; Dirk grabbed his other arm. Jay told the officers to get away from him and struggled to get free. Jay punched Dirk in the chest. The force of the punch sent Dirk "flying through the air"; he broke his right wrist trying to break his fall. When Deal grabbed Jay by the collar, his chain became entangled in his collar and broke. Jay grabbed Deal's arm, squeezing it and yelling, "You broke my chain you white bitch; you're going to pay for it." Jay continued to yell obscenities and racial slurs after he was handcuffed.

\section{Swing Story - An Ambivalent Account}

Assistant store manager Thompson first encountered Jay during the "commotion" on the first floor of the store. Thompson, who 
had just arrived at the scene with Rosenholtz, got between Jay and the guards and told Jay "it's just not worth going through all the hassle." The managers offered Jay a refund because he was upset with the way security was "handling him" and accused them of harassment. As they walked to the service counter for the refund, Thompson tried to calm Jay, who was "a little irate and angry."

Jay waited at the service counter for his refund while Rosenholtz opened the bag and checked his receipt. Thompson, who stood by the side of the counter, "just wanted to get the situation resolved" and thought Jay was "pretty well calmed down." Then, Jay "just tossed" some pennies to Deal, which struck her on the chest and the head.

Dirk came from around the side, identified himself as a police officer, and told Jay that he was under arrest. Dirk grabbed Jay, Jay pulled away, Dirk grabbed him again, and Jay ran out the front door. Jay "more or less just [took] his hands . . . away" from Dirk, but did not strike him. Thompson stayed in the store and did not see the ensuing struggle in the parking lot.

\section{B. Applying Case Theory Concepts to the Stories}

What lessons about case theory can be gleaned from the stories in Jay's case? Rather than providing a literal account of how we constructed case theory, I use the story to explore the limitations of the traditional approach; I present it as a catalyst for a different model that focuses on the client and his experience of the encounter. For me, the case demonstrated that the framework that legal doctrine provides for describing "what happened" is not the exclusive framework. In the new case theory model, the client acts as a source of the framework explaining what the case is about, not merely as a source of facts about "what happened" to be plugged into doctrine.

Although representing Jay prompted us to move from thinking about case theory in traditional ways to creating a different framework, other circumstances hampered us from fully realizing this model. Because Jay missed several scheduled meetings, ${ }^{277}$ the stu-

277. Jay called to cancel the first meeting because he was leaving town for the weekend, and he failed to show up for the rescheduled meeting. After the students left two messages on his answering machine, Jay called and arranged another meeting, which did not occur until three weeks after we received the case. For a thoughtful discussion of the connection between clients seeking greater control over their cases and their desire to cooperate with their attorneys, see Susan Bryant \& Maria Arias, A Battered Women's Rights Clinic: Designing a Clinical Program Which Encourages a Problem-Solving Vision of Lawyering That Empowers Clients and Community, 42 WASH. U. J. URB. \& CoNTEMP. L. 207, 220 (1992). 
dents listened to his story on audiotape long before they heard it from him in person; the tape raised many questions about his perception of the case. Many of these questions were left unanswered when Jay decided to accept the State's plea offer not long after the first interview, bringing case theory development to a halt. Some of my sharpest insights about the case come from reflections after it ended, leaving me with a sense of unrealized possibilities.

\section{Traditional Approach}

A traditional rebuttal theory begins with legal elements and then looks to whether the facts fit the elements of the crimes charged. Disorderly conduct is the crime of acting or speaking in a manner that "offends, disturbs, incites, or tends to incite" onlookers. 278 The State must show that the conduct occurred in a specified public place, that a number of people gathered to observe it, and that the defendant's behavior was offensive, disturbing, or inciting to those gathered. ${ }^{279}$ Because there is little doubt in Jay's case that a clothing store is a location covered by the statute ${ }^{280}$ or that a crowd gathered, the conduct element seems most vulnerable to attack.

As the guards described Jay, his threats and racial epithets were offensive, disturbing, even shocking. To defeat this claim, we would have to show that the guards were either mistaken or lying. But even by Jay's account, his words were profane, loud, and possibly disturbing. Although Jay paints a different picture of the guards, who by their account were polite and almost deferential, their behavior seems irrelevant in the statutory scheme.

Battery is the crime of intentionally touching another person without her consent. ${ }^{281}$ The State must prove that Jay made physi-

278. Reese v. State, 299 A.2d 848, 853-54 (Md. Ct. Spec. App. 1973) (holding that use of the word fucking is not obscene and thus constitutes constitutionally protected speech). The statute provides that "[a] person may not act in a disorderly manner to the disturbance of the public peace ... . in any store during business hours." MD. ANN. CODE art. 27, § 123 (1992).

279. See Barnhard v. State, 602 A.2d 701, 708 (Md. 1992) (finding that there was probable cause to arrest the defendant for disorderly conduct where he "taunted the officers with obscenities, threatened to kill [one of them], and incited the crowd"); Briggs v. State, 599 A.2d 1221, 1227 (Md. Ct. Spec. App. 1992) (holding that the defendant's conduct "disrupted the carnival ... and eventually incited the crowd against the officers").

280. See MD. ANN. CODE art. 27, $\S 123$ (1992) (referring to "any store during business hours").

281. AARONSON, supra note $256, \S 4.12$, at 229 . Although the State charged Jay with assault and battery on Deal, the prosecutor emphasized the physical contact, rather than arguing under an assault theory that Jay had attempted to batter Deal and failed or had intended only to frighten her. Thus, the charge should be viewed as one asserting battery. Id. at 230. 
cal contact with Deal using the coins as an instrument, that he intended this contact, and that she did not consent. ${ }^{282}$ Because none of the participants tells a story in which Deal acquiesced, the issue is whether the coins struck Deal, and if they did, whether Jay intended the contact. If either of these elements is not present, then Jay is not guilty.

The stories on this point diverge more than for the disorderly conduct charge. The State's witnesses and Rodriguez say the coins struck Deal, Jay and Williams thought the coins did not touch her, and Prince did not see where the coins fell. On the question of intent, all the State's witnesses but Thompson characterize Jay's actions as clearly intentional, while Jay's witnesses view the contact as unintentional. Again', in this "he says-she says" contest, someone is either mistaken or lying.

Resisting arrest is the crime of refusing to submit to a lawful arrest. ${ }^{283}$ The State must show that Jay was arrested, that he refused to submit to the arrest, and that the arrest was lawful. A lawful arrest is one in which the individual making the arrest was authorized to do so, identified himself as an officer of the law, and had probable cause to believe that a crime had been committed. ${ }^{284}$

Because Jay concedes that the security guards were attempting to arrest him and that he resisted, our theory must attack the lawfulness of the arrest. By statute, police officers are broadly empowered to make arrests. ${ }^{285}$ Probable cause for an arrest is a reasonable belief that the person charged is guilty of a crime. Thus, the real point of contention is whether Dirk announced in some fashion his status as a police officer. ${ }^{286}$ Although everyone agrees that Dirk was not in uniform, the stories conflict on the question of what Dirk said to Jay in attempting to arrest him.

282. The issue of consent arises because Deal suffered no physical injury. See AAroNson, supra note $256, \S 4.12$, at 229.

283. See Barnhard, 602 A.2d at 704-05.

284. AARONSON, supra note $256, \S 4.80$, at 628 .

285. MD. ANN. CODE art. 27, $\S 594 \mathrm{~B}$ (1992). The term police officer covers a variety of law enforcement positions whose common denominator is that the employers are state and local governments. MD. ANN. CoDE art. 27, § 594B (1992). Persons deputized as "special police officers" may make arrests under more limited circumstances. MD. ANN. CODE art. 27, § 594C (1992); MD. ANN. CODE art. 41, § 4-905 (1993); Waters v. State, 575 A.2d 1244, 1246-47 (Md.), cert. denied, 498 U.S. 989 (1990).

286. On the subject of the guards' arrest powers, the question of whether Dirk and Deal lost the protective cloak around police officers when they assumed the mantle of store security guards at first seems promising, but leads nowhere. While probable cause can be challenged, I do not separately examine this issue because it folds into the disorderly conduct and battery charges. It may perhaps be limited to battery, given that the guards did not initiate the arrest until after the alleged battery. 
In this traditional analysis, each "crime" is treated as a separate and distinct event, rather than as part of a series of interrelated experiences. This approach does not draw a big picture of what happened or why, and it includes very little of the client, except as a source of facts about "what happened." It has a great deal of faith in the existence of an objective version of "what happened," and individuals whose stories deviate from this version are either mistaken or lying. Jay was either loud and obnoxious or not, and he either threw the coins or did not throw the coins. By the same token, Dirk either stated that he was a police officer or did not. Although the model concedes the importance of motivation and credibility in answering these questions, ${ }^{287}$ it provides no real framework for looking at Jay's experience of the event.

\section{Acknowledging Client Life Experience}

How then can case theory be reimagined, given the real limitations of the traditional and client-centered perspectives and both the insights and flaws of the critical approach? An alternative vision of case theory is as a phenomenon that operates at two distinct levels or layers, like geological strata. As lawyers, we must work through the first layer to get to the second layer and the possibilities of imagination.

The first level is the surface level set out in the traditional model of case theory development. This concept of case theory is hierarchical and top-down in its focus, beginning with the law, adding the facts, and finding little room for the client in the interstices. The first layer captures many aspects of a case but leaves much unsaid.

The second level is below ground and rich with almost limitless possibilities. ${ }^{288}$ At this level, case theory is a story that is more than the law and more than the facts. Life, or any one event in life, does not unfold in the neat boxes doctrine envisions but instead proceeds in fits and starts, with the facts all jumbled together. We start with the stories, and work the law back in. Case theory becomes a vehicle for communicating the client's story and meshing his story with the stories told by other participants. It offers images of the client

287. See Berger et AL., Pretrial, supra note 33, at 28 (asserting that a theory that the opposing party lied is "more extreme" than a theory that the opposing party was "mistaken"); SONSTENG ET AL., supra note 39, at 4 (stating that a jury is more likely to believe that the prosecution witness was mistaken than that he was a liar).

288. Of course, ethical rules restrict the arguments lawyers can advance on behalf of their clients, and in criminal cases, these ethical considerations are constitutionalized. See Ogletree \& Hertz, supra note 96, at 35-37 (discussing the Sixth Amendment right to conflict-free counsel). 
and his world and creates a bridge between these images and the law.

a. Revisiting the Story. As we think about how to frame the events at the store, race plays a prominent role in the encounter. The guards believed that Jay perceived the incident as racial but deny any racial intent, arguing that Jay made race an issue by responding to imagined racial insults with his own racial epithets. Yet the client deftly avoids either of these characterizations, never using the word black and admitting only to being angry. It is as if he is speaking in code by not tying the incident directly to race but obliquely conveying that only racism can explain what happened to him. By looking at the case through the lens of race, what light is shed on case theory?

At one level, the fact that Jay is black and the security guards are white makes the encounter a racial incident. We do not need case theory to see this encounter as having something to do with race, given the power of racial images in our society. But once we highlight the role of race as a critical factor, then the story comes into sharper focus. By starting with race, we can see a picture of the case that is very different from the one a traditionalist would see.

Based on what we know of Jay's story, we can create this framework:

This case is about Mr. Jay, a black man, who was shopping at a store and minding his own business until three white store security guards singled him out for surveillance and harassment because he was black. Instead of just going along quietly and playing their game, Jay got angry and shouted out the truth about racism. The guards punished him by teaching him a lesson about daring to speak out and about challenging authority. When they were proven wrong about him being a shoplifter, they got even. They charged him with disorderly conduct, battery, and resisting arrest, but the real crime was being a black man who would not stay in his place. ${ }^{289}$

By using a theory that the guards were racist, Jay's story can be retold through the language of race. There is a haunting "if only" quality to the story - a sense that the incident could have been prevented from getting out of hand. The guards created a crime and then escalated it to the point where Jay was lying on the ground in handcuffs. Although the client's voice comes through with the greatest clarity in this account, the story is more than his voice. Viewed through the lens of race, the story changes. So too do the law and the facts.

289. Other alternatives to a theory that the guards were racist that still involve viewing the incident through the lens of race are discussed infra in Part III.B. 
Mr. Jay is a large black man - quiet and soft-spoken. He was shopping at the store one afternoon, as he often does, looking for bargains. Jay does not have much money because he works part-time as a janitor, but he likes to own nice things and to stretch his money as far as possible. Unlike many men, Jay enjoys shopping. He lives by himself, and shopping is a way for him to feel a part of other people's coming and going. He bought some ordinary household items - a pillow and some washcloths - and then went looking for some clothes.

As he was shopping on the second floor, white security guards with guns followed him for five to ten minutes, watching him closely. The guards gave themselves away by looking down and refusing to look at him when he tried to make eye contact. They watched him but would not admit it, even when he approached Mormon and asked her flat out. Their refusal to make eye contact angered and embarrassed him, making him both invisible and an object of surveillance. They might as well have pointed at him and announced to the world that he was a black man and a thief. This was a lie; he carried a store bag with the things that he had purchased, and a receipt was stapled to the bag. His race was the only reason they were watching him. People who work in stores think that young black men are there to steal.

All Jay wanted was to be left alone, to browse a bit and go home, but they would never stop watching him unless he did something. Jay went up to Mormon and told her that he was a regular store customer, wanting her to think of him as a person, not a stereotype. Instead, she called to report him for shoplifting. The only way to get away from the guards was to leave the store.

Still, the three guards followed him, and he changed his mind about leaving. He wanted to convince the three guards that he was not the person they thought he was; he was not a thief.

When Dirk yelled, "Hey pal, what do you have in the bag?" he was making Jay a public spectacle; other customers in the store could hear the slur. Dirk wanted to prove that he was in charge, that he had the power, and that Jay was nothing. Dirk might as well have called him "boy." Even profanity could not begin to express Jay's feelings. He was enraged, but he still wanted Dirk to put a name to the accusation, to call it what it was.

Dirk's explanation about store policy did not ring true to Jay. $\mathrm{He}$ always carried his purchases in a store bag and had never been challenged for it. If there was a problem with the bag, it was the store's fault. After all, he had asked for a larger bag and the cashier said the bag was the largest one they had.

Jay told Dirk that he had been singled out because he was black, and Dirk denied it. When Jay pressed for an answer, Dirk said, "I don't give a damn!" with an expression of utter contempt and disdain.

Something in Jay snapped. He had gone along quietly all his life without making a fuss. He worked as a janitor and was used to people walking past him as if he did not exist. He pushed mops and 
brooms and wiped up the floor with rags. He had been subservient, invisible. Now he needed to stand up for himself and to force an answer from these security guards. At the same time, he wanted to burst into tears.

The rest was a nightmare. When a crowd gathered, it was as if Dirk had stripped him naked in front of a crowd of strangers. Everyone was looking at him as if he were a thief. The security guards had confirmed the onlookers' worst fears about black men like him.

Still, Dirk would not say the words stealing or shoplifter but called Jay a "punk." Jay yelled back, even though Dirk wasn't listening, to prove that he would not back down, despite the fact that Dirk had the gun and the power. He wanted Dirk to know that he was not afraid of him - that if Dirk had not had a gun, he would have taken charge. Right after that, the managers came up. The managers seemed to take his side by offering him a refund, and the black manager, Thompson, put his arm around Jay and walked him to the service counter. Although Jay felt reassured by this gesture, he still felt the sting of the racial insult.

Dirk and Deal still would not leave him alone. They followed him up to the service counter and would not take their eyes off of him. They did not belong there, because he was waiting for a refund and security guards don't handle refunds. Their presence was a continuing slap in the face; their stares felt like a taunt. Suddenly, the refund seemed like an insult, a cheap way to buy him off and keep him quiet.

Instead of waiting for the refund, Jay dug in his pocket for some change. He wanted to throw the refund in their faces because they had offended his dignity, but he never thought about whether the coins would hit them. Jay could not afford to lose quarters, but he would lose his point if he threw the change and then bent down to pick it up. So he very deliberately chose pennies. The message was that money was not the issue for him. The issue was his reputation. Maybe they thought he meant he made more money than they did. They would think that was the message, even if he never made that comparison. All he meant was that they shouldn't assume that black men had no money and had to steal to have nice things. To them, money was a symbol of status and prestige from which they - and blacks - were excluded.

He could not believe it when Deal cried out "assault and battery" and said something about arresting him. He hadn't hit anybody. How could Dirk arrest him? Only police officers can arrest someone, and Dirk was a security guard.

He just wanted to get out of the store and away from these crazies who were chasing him with loaded guns. He did not even think about the fact that he was leaving the refund behind. Once he got outside, he stopped thinking and just reacted. He struggled to break free from the police, but he never hit anybody.

Looking back on the arrest, the whole thing seemed like a set-up. From the time that Thompson walked him up to the service counter, Dirk and Deal were just looking for an excuse to turn the tables. 
They were angry that the managers took his side and were going to give him his money back. The pennies were no big deal; Deal and Dirk just wanted to get Jay under their thumb, to prove that they could keep him down.

The sale, called a "Bash," was the ultimate irony. The Bash was an open invitation to the community to come and shop, but when he got to the store, they slammed the door in his face. Jay never knew what hit him until he was lying on the ground in handcuffs.

Much is imagined in this story because we did not brainstorm this race theory with our client. Not only does race matter in the larger sense of our client's shared experiences with other black men who have experienced racism in their lives, ${ }^{290}$ but so too does our client's personal experience of the encounter. We knew little about his life experiences and attitudes, or how they shaped how he understood the guards' suspicions that he was a shoplifter. Nonetheless, even this incomplete story tells us much of value about legal doctrine and the importance of "life facts."

b. Enriching Legal Doctrine. Thinking about the incident in the store as a racial encounter changes how we look at legal elements such as behaving in a "disorderly" manner, intending to strike another person, and identifying oneself as a police officer. It brings the dry language of the law alive and gives its words shape and meaning.

Disorderly conduct. In telling a story about a man who was pushed to his limits on the intensely personal issue of race, Jay suggests a different answer to the question of what kind of conduct is disorderly. Perhaps the law of disorderly conduct includes a concept of provocation - the idea that some behavior, such as accusing an innocent person of shoplifting, is sufficiently provocative that any verbal response, even one as vehement as Jay's, could be justified.

Under this interpretation, we might invoke a kind of speech self-defense theory in viewing the guards, rather than Jay, as disorderly. Loud, even belligerent, behavior may be excused under circumstances when someone else starts the disturbance. Rather than simply being disruptive, Jay may have been justified in defending himself against individuals who were themselves disorderly.

290. See Studs Terkel, Studs Terkel Ponders the Meaning of Race and Riot, People MAG., May 18, 1992, at 105 ("A black man once said to me that race is always on his mind, from the moment he wakes up to the time he goes to sleep."). In interviews of black men, Essence magazine quoted one interviewee: "We've all had the experience of trying to hail a cab and being ignored, of being followed around in a store like a thief on the make, of being mistaken for a messenger when we have an appointment to see the boss." Charles N. Jamison, Jr., Racism: The Hurt that Men Won't Name, EssENCE, Nov. 1992, at 62, 64. 
Although the case law interpreting the statute envisions an area of protected speech under the First Amendment, ${ }^{291}$ it does not specifically address the issue of provocation. Yet a closer look at the law, in light of our theory, creates room for such an interpretation. ${ }^{292}$

The strength of this theory may correlate with Jay's racial identification; perhaps a black man wrongly accused of shoplifting responds differently than a white man does. On the one hand, the cases do not seem to suggest that conduct should be viewed in terms of the personal characteristics of the accused. Nonetheless, once the accused person's intent - whether to disturb or simply to respond - is relevant, ${ }^{293}$ it may be that the person's subjective experience of the insult matters.

Indeed, taking seriously Jay's experience of the incident may permit a First Amendment defense that is more affirmative than a speech self-defense theory. While the self-defense theory is predicated on the legitimacy of Jay's response to the guards, it does not address any effort he may have made to publicize his outrage further. For instance, he may have sought to go beyond a one-on-one encounter with Dirk by protesting more broadly and seeking to recruit others to his point of view. Rather than simply parrying the guards' thrusts, he may have tried to draw attention to how he was being treated. Viewed in this light, his actions may have been a legitimate attempt to galvanize the crowd against the racist guards. While the law seems to draw the line at incitement,294 perhaps if such actions take the form of shared outrage rather than interfering with police business, they might receive protection. Perhaps all Jay wanted was for the crowd to see that he was being mistreated because he was black.

But until we have a framework for thinking seriously about the reasons for the client's anger or why the actions of the security

291. Diehl v. State, 451 A.2d 115, 118-19 (Md. 1982) (interpreting MD. ANN. CodE art. 27, § 121 (1992)), cert. denied, 460 U.S. 1098 (1983). When the students first researched the case law, they found no potential clash between the statute and the First Amendment. Because the students were competent researchers, their oversight puzzled me. In hindsight, I wonder whether their own resistance to using race in the case may have impeded their reading of the cases. See discussion infra section III.C.

292. For example, in holding that the defendant's speech was protected under the First Amendment, the Diehl court noted that the officer's unlawful order for a passenger to return to the passenger seat of a car stopped for a traffic violation "precipitated the entire episode," while the defendant's speech "was merely a response." 451 A.2d at 118.

293. 451 A.2d at 118-19 (finding that the evidence did not indicate that the defendant "intended to disrupt the quiescence of the neighborhood").

294. 451 A.2d at 119 (noting that protest is permissible so long as it does not "precipitate[ ] public disorder amounting to a breach of the peace"). 
guards were so provocative, both the provocation and protest interpretations pass almost unnoticed. Anyone who causes a scene is for that reason alone guilty of being disorderly. It is the client's experience as a black man, or more accurately, the way we translated this experience, that reveals a different way of looking at the question. We understand the law differently once we acknowledge the relationship between racial insult and conduct.

Battery. Thinking about the events in terms of race also envisions the crimes with which Jay is charged as interconnected rather than as isolated events and thus transforms the doctrinal boxes of disorderly conduct and battery. For example, Jay's act of deliberately picking pennies out of the change in his pocket and flinging those coins at Deal at first seems to support the State's charge that Jay intended to strike Deal. His action in sorting the pennies was a careful, deliberate act that seems inconsistent with an act of passion, accident, or mistake. ${ }^{295}$

Viewed in light of race and our insight into disorderly conduct, however, this act suggests a different kind of intent. Jay selected the pennies, not with the intent to strike Deal, but with the intent to make a statement about being wronged. If the calculated gesture of selecting the pennies is an extension of the act of shouting in the store, the deliberate character of the act goes to speech. Jay's act can then be seen as having the unintended consequence of striking Deal - as a technical battery, a byproduct of an act whose real purpose was simply speech. ${ }^{296}$

Moreover, if we portray the act of throwing the pennies as an extension of speech, ${ }^{297}$ then we can piggyback on the self-defense theory for disorderly conduct. Just as Jay's shouting can be understood as defensive rather than offensive, so can throwing the pennies be seen as an act of self-protection rather than an attack. In throwing the pennies, Jay was defending himself, not against a lit-

295. For a discussion of how another client's insight into his behavior gave my clinic students a better understanding of case theory, see infra note 359 .

296. In contrast, courts draw a bright line between speech and conduct in finding that certain conduct is disorderly even when the accompanying words are not. See, e.g., Briggs v. State, 599 A.2d 1221, 1225 (Md. Ct. Spec. App. 1992) (holding that the defendant's cursing was protected but that his actions of seizing gambling money and slamming dice onto the gaming table were not). Here, however, Jay's actions were so closely connected to his words that the line between actions and words is fuzzier. I am not suggesting that any physical act could be excused under this theory; Jay could not punch Deal in the face and then claim that the assault was an act of pure speech.

297. If racist speech is like an assault, then perhaps we can see the guards as striking the first blow. See Charles R. Lawrence III, If He Hollers Let Him Go: Regulating Racist Speech on Campus, 1990 Duke L.J. 431, 452 ("Assaultive racist speech functions as a preemptive strike. The racial invective is experienced as a blow, not a proffered idea ...."). 
eral physical attack, but against an attack that felt physical in its force. 298

Resisting arrest. Finally, thinking about Jay's perceptions of the identity of the security guards also helps us undercut a critical element of proof to the charge of resisting arrest - the requirement that the arresting officer identify himself as a police officer. The case law assumes that the relevant question is what Dirk did, not how Jay interpreted his actions. ${ }^{299}$ So long as the officer states that he is a police officer, shows a badge, or otherwise announces his status, such as by wearing a uniform, this element is satisfied.

Jay makes us think of this question differently. Jay already had a picture of who Dirk was, regardless of any statement Dirk might have made. Even if Dirk had identified himself as a police officer, Jay may never have heard him, either because he was not listening, or because the statement seemed sufficiently improbable that its content never registered. Even if he heard the statement, Jay simply may not have believed it. In Jay's experience, cops, white or black, do not keep their identity a secret when they harass someone, especially cops as puffing and boastful as Dirk. If Dirk were really a police officer, he would have announced it during the argument at the bottom of the escalators as part of his poweroplay to put Jay in his proper place. ${ }^{300}$ Thus, Dirk's statement about being a cop seems at best questionable and at worst laughable. Given that Dirk and Deal were not dressed as police officers and had not at any point previously in the lengthy encounter identified themselves as police officers, what reason had Jay to pay any attention to Dirk's assertion?

298. Some case law suggests that the slightest touching may constitute a battery. See, e.g., Lamb v. State, 613 A.2d 402, 412-14 (Md. Ct. Spec. App. 1992). But often-overlooked language in jury instructions and case law requiring that the contact be "offensive" may provide room for an argument that not every physical contact without consent is a battery. See Maryland Pattern Criminal Jury Instructions $\$ 4.04$ (1991); 613 A.2d at 412 n.4. Although the instructions do not explain the meaning of the term offensive, Jay's experience suggests that the minimal contact that occurred here might not meet this standard.

299. See Jordan v. State, 300 A.2d 701, 703-05 (Md. Ct. Spec. App. 1973) (rejecting subjective interpretations of police statements of authority to arrest). Most cases simply assume the authority to arrest because the officers' status is not challenged. See, e.g., Barnhard v. State, 602 A.2d 701 (Md. 1992). In contrast, Maryland courts apply a subjective standard when a defendant urges that an illegal arrest provides legally adequate provocation to reduce murder to manslaughter. See Blake v. State, 349 A.2d 429, 433 (Md. Ct. Spec. App. 1975).

300. See Jamison, supra note 290 , at 123 (citing encounters with police as examples of racism experienced by black male adolescents). For an insightful account of the relationship between the police and the black community, see Homer Hawkins \& Richard Thomas, White Policing of Black Populations: A History of Race and Social Control in America, in OuT OF Order? Policing Black People 65 (Ellis Cashmore et al. eds., 1991) ("In every major city where blacks lived in large enough numbers to be noticed and feared by whites, the white police force was allowed and often encouraged to keep 'the niggers in their place." "). 
c. Reenvisioning Facts. In addition to enriching our notion of legal elements, case theory also makes facts come alive, including facts that do not seem to fit a particular legal element. How can a case theory based on race, and on Jay's life, change the meaning of facts?

In viewing Jay's case in light of the doctrine-driven traditional approach, the key factual disputes are whether Jay was loud and used profanity, whether he deliberately threw the coins at Deal, and whether Dirk adequately identified himself as a police officer before attempting to arrest Jay. As we have seen, a race case theory makes us think anew about these legal elements and changes the relevant facts. Perhaps Jay could have been loud and profane, have thrown the coins in the direction of Deal, and have heard Dirk identify himself as a police officer, and still not be guilty of a crime. Instead, the focus shifts to the reasons Jay became so angry in his interactions with the guards, what they did to provoke him, how to view the act of throwing the coins, and how Jay understood what Dirk said about his status as a police officer.

But case theory also gives facts meaning apart from doctrine. Case theory works at two levels, both at the enriched doctrinal level and, in an even purer way, at the level at which race is the frame, regardless of how it shapes our understanding of doctrine. This is the level at which we can say, "Now the story makes sense."

This shift, both in doctrine and in frame, forces us to look at Jay and his life experience. In this scenario, although the facts about "what happened" matter, other facts outside those parameters matter just as much. These are "life facts" - facts about the lives of the people in the case.

In moving from case theory to life facts, we must sift through the morass of facts to discover the critical facts. It is helpful to begin by identifying a few "good" and "bad" facts. The good facts are the critical underpinnings of case theory, leading us to accept our client's perspective on the encounter. The bad facts undercut this perspective, leading us to question his perceptions.

When race is the image that drives the case, the good life facts are that Jay is black, that he is a gentle and soft-spoken man, that he works as a janitor, that he was not stealing that day, that he has never been arrested or convicted of any crime, and that he likes to shop. While these facts might matter even if race were irrelevant, they are more powerful under our theory that the encounter was racial. 
We are drawn to Jay because he makes himself vulnerable in revealing that he could not find a pair of jeans in his size in the store. We see him as cautious and hesitant to expose his own vulnerabilities, using his charges of racism as a shield, not a weapon. By removing this shield, he has exposed something of himself in telling the guards, two strangers, that race matters to him, and so does his dignity. He has put himself on the line by announcing that something as personal to him as his race could cause another person to treat him with contempt. Viewed in this light, his allegations seem less like an accusation and more like a painful query - "Are you treating me differently because I am black?"

The security guards describe Jay as hostile and aggressive - a man willing to fling unwarranted charges of racism. Yet Jay works as a janitor. A janitor mops floors and cleans up other people's messes. A janitor looks down, speaking only when he is spoken to. A janitor does not challenge authority unless he is pushed to the wall.

Jay was not a thief that day and has never been a thief or a criminal of any sort. We reluctantly admit that if we had joined the crowd in the store that day and seen the guards interrogating him, we probably would have assumed that he was shoplifting. We are made uncomfortable by our realization that we might have made the same mistake the guards made.

It matters not only that Jay paid for the items in the bag but also what those items were. There is something familiar, even poignant, about his purchase of familiar household items, such as washcloths and a pillow. Who these days, besides your grandmother, uses a washcloth? We would have had a very different picture of Jay and his case if the items in the bag had been a boombox, rap music, or Nike tennis shoes. ${ }^{301}$ The kind of man who shops for pillows is not the kind of man who goes on a rampage in a store..$^{302}$

Yet this image is counteracted by the fact that Jay wore a gold chain that day. Suddenly, Jay is not a single man shopping for comforting household items such as a pillow and washcloths. He is a black man fond of flashy jewelry, like a pimp or a drug dealer. Unless we can explain the chain in a way that does not implicate these

301. See Tom Wolfe, The Bonfire of the Vanities 110 (1987) (describing the wide gulf in a Bronx courtroom between white lawyers and black defendants wearing white "goto-hell" sneakers).

302. Of course, all these images concerning what kind of man Jay is can be challenged as gross generalizations, but they are nonetheless powerful. Obviously, black men who buy boomboxes, rap music, or Nike shoes are not by virtue of this fact prone to rampage, nor are men who buy pillows incapable of committing horrific crimes. 
racist stereotypes, ${ }^{303}$ this image is at odds with the image created by other facts.

Facts from other peoples' lives also seem significant. Prince and Williams are black; Rodriguez is Latino. Prince lives with his father and sister, is a student who works part-time, and aspires to be an engineer. Williams lives with his wife and three children with whom he goes shopping. Rodriguez lives with his aunt. These men are people like us. They have families; they go shopping; they are not troublemakers. None of these men knew Jay before his encounter with the security guards. All came to his assistance later.

The witnesses for the State also have lives, but we know little about them. Perhaps the most revealing thing we know about Dirk is that he thought of Jay as a "caged animal." That image would probably not surprise Jay.

Mormon tells us, in what at first seems like a non sequitur, that she is involved in an interracial marriage and that she explained this to Jay. ${ }^{304}$ She does not state the race of the person with whom she is involved. Mormon wants us to believe that because she is involved with a person of a different race, she cannot be a racist. ${ }^{305}$ Yet if Mormon were involved in a relationship with an Asian American, for example, this fact would have little to do with her attitude towards blacks. Even if she were involved with a black person, this fact hardly renders her immune from the label racist. Yet her pronouncement has a certain surface appeal, despite the questionable assumptions on which it rests.

We know that Dirk and Deal are police officers who moonlight as security guards. We can only guess about other aspects of their lives. They probably receive low pay and work second jobs to make ends meet. They expect to be obeyed because they are police officers, and they transfer that expectation to other interactions.

303. For instance, if the chain were given to Jay by his grandmother, its message might be a neutral, or even favorable, fact.

304. Mormon is a key participant because she confronted Rodriguez and Jay. If her motives were pure, they soften the impact of the actions of Dirk and Deal. If her motives were impure, then the entire encounter is tainted.

305. This is not much different than saying, "I have black friends, so therefore I am not a racist," or as Charles Garry, an attorney for then-Black-Panther Huey Newton, belatedly recognized, "I thought I knew something about Negro America because some of my most intimate friends are Negro professionals .... . It wasn't a week or two weeks after I got this case and I came to the conclusion that I knew absolutely nothing about black America ...." Drew Findling, Closing Argument: Tapping the Human Experience, 42 Mercer L. Rev. 659, 662 (1991) (citing Ray Edward Moses, Jury Argument in Criminal Cases 168-69 (1985)). 
They think a person who refuses to follow their orders is a troublemaker, or worse.

Thompson plays an especially important role in a case theory based on race, while under a different case theory his role would be anomalous. He testifies for the State, but acts as a turncoat witness who makes an artful effort to give Jay as much as he can. This equivocal testimony makes more sense when we see him as a black man caught between two worlds - between Jay's world and the world of his white colleagues. During the actual incident, he immediately felt the need to separate the trio of Dirk, Deal, and Jay. We sense that if the decision had been up to him, he would have let the incident go. But he came to the scene too late to derail an encounter already rushing to its inevitable conclusion.

Attention to life facts also reminds us to expand the time frame beyond the immediate incident. ${ }^{306}$ Before: Mormon and Dirk ask Rodriguez to leave the store. When he refuses, Dirk calls Rodriguez a "punk" and "boy." After: in a cheap shot, after Jay is lying on the ground in handcuffs, Deal punches and slaps Jay and rips off his gold chain.

As Jay's story demonstrates, thinking of case theory as life experience opens up a world of possibilities. For the lawyer, legal doctrine can change in the process; for the client, case theory fits with his experience by highlighting the importance of his life facts. This can give the client a sense of vindication and will resonate with some juries.

\section{Reconceiving Case Theory: Implications for the LAWYER-CLIENT RELATIONSHIP}

\section{A. Creating a Theory of Case Theory}

In looking at Jay's case, we have come a great distance from the traditional model of case theory. Once we entertain the notion that Jay might have correctly perceived that he was singled out because he was black, we can better understand why he and others acted as they did. Jay was just sick and tired of being treated badly.

In revisiting the story, however, the story that we tell is not so different from the kinds of stories that good lawyers have been telling for years. These kinds of case theories, however, have not been captured in academic theory, whether traditional, client-centered,

306. For a discussion of the importance of time frames and how they relate to the framing of a case, see Robert Heidt, Recasting Behavior: An Essay for Beginning Law Students, 49 U. Prrt. L. Rev. 1065, 1086-91 (1988). 
or critical..$^{307}$ It is as if we have forgotten what we know to be true and have forsaken familiar ground for theory that fails to reflect how case theory really works. Ironically, it seems that theory and practice have truly diverged in efforts to describe a model of case theory. ${ }^{308}$

My aim is to articulate a theory of case theory that is truer both to the client's life experience and to what it is that lawyers actually do. By defining case theory as an explanatory statement linking the case to the client's experience of the world, we create a context for seeing what we might not otherwise see. Case theory creates a perspective for the facts, relationships, and circumstances of the client and other parties that is grounded in the client's goals. Case theory makes actions seem quite reasonable that at first seemed unreasonable, and it allows us to accept the client's story and at the same time have a plausible explanation for other stories.

The account of theory that has most influenced my thinking about case theory is not a work about lawyers and clients but rather Robert Coles's account of the psychiatrist-patient relationship in The Call of Stories. ${ }^{309}$ Although the lawyer-client relationship dif-

307. An important exception is clinical theory, in which çlinical teachers have proposed more creative interpretations of case theory. See, e.g., Cook, supra note 14, at 54 (describing case theory as a "new perspective[ ]" arising from the "exchange of stories"); id. at 62 (arguing that in developing case theories a lawyer "chooses facts and creates contours of meaning"); Dinerstein, supra note 10, at 975-77 (noting the need for case theory to incorporate the perspective of the client); Shalleck, supra note 14, at 139 n.22 ("[C]ase theory draws upon, integrates, and shapes the facts and the law in light of what the client wants to achieve in the legal action."). Others have stressed the importance of presenting the client's case as grounded in the client's life experiences. See, e.g., Julius Getman, Voices, 66 Texas L. Rev. 577, 582-83 (1988) (arguing for greater emphasis on human voice as distinct from professional, critical, or scholarly voice); Michael E. Tigar, Voices Heard in Jury Argument: Litigation and the Law School Curriculum, 9 REv. LiTiG. 177, 190 (1990) ("[T] he advocate cannot get by with an abstract reference to her own worldview. Instead, the advocate must evoke the client's and the jurors' human concerns.").

308. Just a glance at media accounts of well-known trials demonstrates that the commonsense understanding of case theory is closer to the real thing than the models that have been developed. For example, in the opening statements of the Lorena Bobbitt trial, the defense lawyer told the jury that the case is about whether "a life is more valuable than a penis." Martin Kasindorf, Bobbitt Denies Assault on Wife, NewsDAY, Jan. 11, 1994, at 6; see also infra notes 320-57 and accompanying text. The claim that I make here is a claim about how lawyers conceive of case theory. I do not make the claim that lawyers typically brainstorm case theory with their clients or involve clients in decisions about case theory.

309. See Robert Coles, The Call of Stories (1989). Coles's work has inspired other legal scholars. See, e.g., Kathryn Abrams, Hearing the Call of Stories, 79 CAL. L. REv. 971, 971 (1991) ("Coles exemplifies the kind of fruitful, humane attention that narrative scholars and others are beginning to bring to the law."); Theresa Glennon, Lawyers and Caring: Building an Ethic of Care into Professional Responsibility, 43 Hastrngs L.J. 1175, $1181 \mathrm{n} .30$ (1992) (citing Coles to support the importance of lawyers' "helping the client tell his or her story in a clear and compelling way"). In fact, Coles has examined the lawyer-client relationship in other contexts, having authored an article on Dickens's legal fiction, see Robert Coles, The Keen Eye of Charles Dickens, 35 HARv. L. ScH. BulI. 30 (1984), and having taught a seminar at Harvard Law School entitled "Dickens and the Law," which examined the toll 
fers in some respects from the psychotherapist-patient relationship, ${ }^{310}$ Coles's account in chapter 1 - entitled "Stories and Theories" - has much to offer a conception of case theory grounded in client lives.

As a psychiatric resident, Coles worked under the supervision of two psychiatrists, Dr. Binger and Dr. Ludwig. Coles's first patient was a driven woman who paced up and down the corridors of the psychiatric ward incessantly and in so doing acquired the name "the hiker."311 In discussing this patient in supervision meetings, Binger readily diagnosed the woman as "phobic," a familiar conceptualization that at first was reassuring. ${ }^{312}$ Binger focused on categorizing her condition according to familiar psychiatric precepts and formulating an immediate diagnosis of her "psychodynamics."

In contrast, Ludwig followed a radically different approach. $\mathrm{He}$ stressed the importance of patients' talking about events in their lives before doctors formulate solutions to their problems and the need for open-ended conversations without theoretical constructs. ${ }^{313}$ He urged Coles to listen to patients' stories before offering ready conceptualizations of their problems and to recognize that diagnosis is only a guess - an effort to connect a particular patient to a category of patients. 314

In time, Coles learned to embrace Ludwig's vision of the psychiatrist-patient relationship. In this vision, theory is not abstract and accepted medical doctrine but, instead, the "enlargement of observation." 315 As Ludwig put it: "The people who come to see us bring us their stories. They hope they tell them well enough so that we understand the truth of their lives. They hope we know how to interpret their stories correctly. We have to remember that what we hear is their story." "316 In this way, "each patient [can] be a

that professional roles take on lawyers and their impact on justice, and the impenetrable nature of legal rhetoric. Coles is also the author of the foreword to RICHARD D. Kahlenberg, Broken Contract: A Memoir of Harvard Law School (1992).

310. Dinerstein, supra note 26, at 538-44; Ellmann, supra note 11, at 1010-15 (discussing the difference between client-centered psychotherapy and client-centered lawyering). For comparisons between the doctor-patient relationship and the lawyer-client relationship, see John P. Heinz \& Edward O. Laumann, Chicago Lawyers: The Social Structure of THE Bar 333-42 (1982); 8 John HenRy Wigmore, EvidenCE in Trials at Common LaW $\$ 2380$ (a), at 828-32 (J.T. McNaughton rev. ed. 1961) (distinguishing legal and medical privileges); Dinerstein, supra note 26, at 525, 532-34 \& nn.142-44.

311. CoLEs, supra note 309 , at 1-3.

312. Id. at 3-4.

313. Id. at 7-8, 14.

314. Id. at 6-8, 13-15, 18-24, 26-27.

315. Id. at 20 .

316. Id. at 7. 
teacher,"317 and psychiatrists can "make over [patients'] stories into something of our own." 318 Theories are stories infused with the particularity of each patient's experience in the world.

Just as Coles learned to avoid deceptively easy theoretical constructs and to see theory as simply stories writ large, so too can lawyers come to see case theory, not as finite and confined, but as an account of what happens in the world, mediated by clients' unique experiences of the world. By taking to heart Ludwig's admonition to Coles for " 'more stories, less theory," "319 lawyers can see case theory as stories that rely on the law. There are as many case theories as there are clients.

While this view of case theory is noticeably absent from legal scholarship, it thrives in popular legal culture. Recent media accounts of highly publicized trials present a picture of case theory that is driven by the life experiences and identities of clients and their surrounding communities. The Long Island Railroad massacre, the conspiracy trial related to the World Trade Center bombing, and, of course, the O.J. Simpson trial offer a rich ground for examining race and case theory. ${ }^{320}$ Like the well-established battered woman syndrome defense, ${ }^{321}$ these cases demonstrate how perspectives on race and other identities can be used to fashion case theory.

The case of Colin Ferguson, who shot and killed six commuters and wounded nineteen others on the Long Island Railroad, parallels the reconceived story of Jay's case. The crimes in the two cases are vastly different, but both cases create room for case theories that examine the client's life facts coupled with an understanding of racism. Ferguson, who represented himself, rejected one case the-

317. Id. at 22 .

318. Id. at 19.

319. Id. at 27.

320. Case theory has also played an important role in other high-publicity cases. See Seth Mydans, Menendez Trials' Collapse Discourages Both Sides, N.Y. Times, Jan. 30, 1994, at A16 (criticizing the prosecution in the trials of Lyle and Erik Menendez for failing to choose a single theory explaining the defendants' motive); Sonja Steptoe, A Damnable Defense: Not only did Mike Tyson lose his rape case, but his lawyers perpetuated a racial stereotype, SPORTS ILluSTRATED, Feb. 24, 1992, at 92, 92 (noting that the prosecutor's theory of the case included portraying Tyson as "being almost playful toward the [beauty pageant] contestants").

321. For the history of this defense, see CyNthia K. Gillespie, Justifiable Homicide: Battered Women, Self-Defense, and the Law (1989); Lenore E. Walker, The Bat-

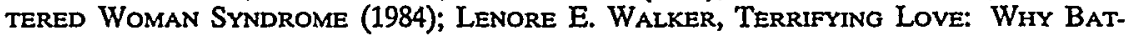
TERED WOMEN KILL AND How SOCIETY RESPONDS (1989). For a fascinating account of the development of a self-defense theory that incorporated the perspective of the client, a Native-American woman accused of murder, see Elizabeth M. Schneider, The Dialectic of Rights and Politics: Perspectives from the Women's Movement, 61 N.Y.U. L. REv. 589, 606-10 (1986). 
ory - the "black rage" defense ${ }^{322}$ — crafted by his former defense attorneys in favor of a different theory - a theory that whites conspired to charge him with the crime, which was committed by a white passenger who seized the gun from Ferguson while he slept. ${ }^{323}$

If Ferguson was competent to stand trial, the choice of which story to tell should have been his; nonetheless, the black rage defense would have differed from Ferguson's race-based defense in focusing on Ferguson's life experience, not just on the fact that he is black. Black rage is an explanation for the rage and anger that blacks in America feel toward those they view as their oppressors, namely whites. Black rage emerges from group conditions, although not every member of the group is enraged enough or out of control enough to commit murder. ${ }^{324}$

One story that Ferguson could tell gives shape to the black rage defense. ${ }^{325}$ Colin Ferguson grew up in a privileged family in Jamaica that employed a cook and a gardener; he moved to the United States when he was twenty-four years old. His brother remembers Ferguson as a man who "never ... curse[d] other races." "326

322. His former lawyers borrowed the term black rage from a book written in 1968 by black psychiatrists William H. Grier and Price M. Cobbs. See William H. Grier \& Price M. Cobbs, Black Rage (1968).

323. See Dale Russakoff, N.Y. Defendant Keeps His Own Counsel, WAsh. Post, Jan. 27, 1995, at A3. The efforts of his former attorneys to undermine his defense and to persuade the judge to find Ferguson incompetent to stand trial, see John T. McQuiston, Advisor to L.I.R.R. Suspect Threatens to Quit, N.Y. TIMES, Feb. 7, 1995, at B8, raise troubling ethical issues. Ironically, now that Ferguson has been convicted, he reportedly plans to argue in posttrial motions and on appeal that he was incompetent to stand trial - an argument that clearly contradicts his previous position that he was competent to stand trial and legally sane. See John T. McQuiston, Appeal Strategy of L.I.R.R. Killer Is Insanity Issue, N.Y. TIMES, Feb. 19,1995 , at $\mathrm{A1}$.

324. " 'People bear all they can and, if required, bear even more. But if they are black in present day America they have been asked to shoulder too much. ... Turning from their tormenters, they are filled with rage.' WILLIAM M. KUNSTLER, MY LifE As A RADICAL LAWYER 386 (1994) (quoting GRIER \& CoBBS, supra note 322, at 4). In the Ferguson case, the black rage defense would have been used in conjunction with a traditional insanity plea, rather than standing on its own as a separate and independent defense. Arguably, Ferguson's rage is a catalyst for insanity, joining with his psychological problems to turn the black rage that otherwise justifiably exists within the black community into an uncontrollable murderous rage. According to one of his legal advisors, Ferguson preferred to run the risk of being found guilty of murder to being found insane. John T. McQuiston, Advisor Says L.I.R.R. Suspect Prefers Conviction to Insanity Finding, N.Y. TIMES, Feb. 10, 1995, at B5.

325. The following facts, which I have altered slightly to make the point about case theory, are detailed in Shirley E. Perlman et al., An Angry Young Man; The troubled times of Colin Ferguson: from a privileged boyhood to chaos on the LIRR, NEwSDAY, Mar. 6, 1994, at 4.

326. Id. at 5 . 
When he arrived in the United States, he took jobs such as running a cash register at a liquor store, although he eschewed sweeping or stocking shelves as beneath him. He felt that he was constantly being put down because he was black, and he began to feel angry about the discrimination he felt and about whites who got all the breaks in life.

While he was unable to get the jobs he wanted and felt he deserved, he also was ridiculed at Adelphi University for having radical political ideas and for being vocal about the need for black revolution. Because he was viewed as hostile toward white students and professors, he was eventually asked to leave the university. $\mathrm{He}$ became more and more alienated, and more and more angry. His rage was reaching a boiling point.

Ferguson then went to California to look for a job and to collect his thoughts. He returned to New York with a semiautomatic weapon that was popularly used for target shooting and selfdefense. For Ferguson, the gun was a symbol of his belief that he was on the defensive against his white oppressors. After that, he simply lost control.

A race-based theory similar to the black rage defense is the "urban survival syndrome," which was argued in the trial of Daimion Osby, a young black man from Fort Worth, Texas, who shot and killed two unarmed neighborhood black youths. ${ }^{327}$ Osby's defense lawyer did not deny that Osby pulled the trigger but instead argued that his client was so fearful from years of living in the inner city that he almost reflexively pulled the trigger in order to defend himself. This defense was crafted to explain how black inner-city residents can be so afraid for their lives that a very small amount of provocation can actually set off deadly consequences. 328 Osby was convicted in his second trial, ${ }^{329}$ although the jury had deadlocked 11-to-1 in the first trial. ${ }^{330}$

No discussion of race and case theory would be complete without some mention of the ongoing double-murder trial of O.J. Simp-

327. "Urban Survival" trial ends with hung jury, Hous. Chron., Apr. 21, 1994, at A1 [hereinafter Hung Jury]; Jury Rejects 'Urban Survival' Defense, WASH. Post, Nov. 13, 1994, at A16 [hereinafter Urban Survival]. For a discussion of the black rage defense and the urban survival syndrome, see Michael Fumento, From Battered Wives to Battered Justice Syndrome, WASH. TIMEs, Jan. 8, 1995, at B3.

328. While this defense on its face is not limited to people of color, the demographics of most inner-city neighborhoods suggest that the opportunity to raise this defense would most frequently arise for defendants of color.

329. See Urban Survival, supra note 327, at A16.

330. See Hung Jury, supra note 327 , at A1. 
son. While a complete analysis of that case is beyond the scope of this article, ${ }^{331}$ several aspects of the case show how lawyers make actual use of case theory for their clients. O.J. Simpson, who won the Heisman trophy for the University of Southern California and played for the Buffalo Bills in the National Football League before gaining widespread fame in commercials and as a football commentator, is currently on trial for first-degree murder for the brutal slashing deaths of his ex-wife, Nicole Brown Simpson, and her friend, Ronald Goldman.

From the beginning, the media has reminded the public that all of our views of the case are shaped by individual perspective and that our experiences and values affect what we see and believe to be true. ${ }^{332}$ Simpson's defense lawyers have highlighted the issue of black celebrity status in framing Simpson's case theory, attempting to turn those aspects of Simpson's case that might be used against him - race and celebrity status - into strategic advantages. By raising allegations against the Los Angeles Police Department of a sloppy and biased investigation ${ }^{333}$ - allegations that require little prompting in the wake of the Rodney King case ${ }^{334}$ - the defense has played a racial card that many see as valid. ${ }^{335}$ Part and parcel of

331. The case has generated so much publicity that NEXIS has added a research file covering only that case. By now the Simpson case has reached the comic strips, where a defense attorney for "Bill the Cat" invokes case theory by weaving together references to Elvis, Michael Jackson, Prozac, avenging angels, and kitty bigots to frame an outlandish argument that his client is innocent of a chainsaw attack. Berkeley Breathed, Outland, WASH. Post, Oct. 23, 1994, $\$ 1$ (Comics), at 3 . It appears that the cat reference is to Simpson's humming the tune "Memories" from the musical Cats during jury selection. See Christine Spolar, An Animated O.J. Takes Center Stage in Jury Selection, WAsH. Post, Oct. 2, 1994, at A18.

332. See, e.g., Stebbins Jefferson, Fallen Hero Worship, Palm BeAch Post, Aug. 14, 1994, at $1 F$ (quoting Kimberle Crenshaw, professor of constitutional law at UCLA, as saying, "It's a Rorschach (test) on race and gender. Whatever your issue is, you can look at this case, and ... see it.").

333. Simpson Team Faults Probe of Slayings; Blood Evidence Was Contaminated, Defense Asserts, WAsh. Post, Jan. 26, 1995 at A1 (describing the defense's case theory as it was set out in their opening statement).

334. See Fire and Fury, Part 5 - A Case of Black and White (CNN television broadcast, Oct. 16, 1994) [hereinafter Fire and Fury] (suggesting that the effect of the famous police beating of Rodney King has made it difficult for the public to believe what the Los Angeles Police Department says about the Simpson and Goldman murders); CNN \& Company (CNN television broadcast, Oct. 16, 1994) (showing agreement among a panel of criminal defense attorneys that, in light of the riots following the verdict in the Rodney King beating trial, O.J. Simpson's attorneys should not suggest bias on the part of the Los Angeles Police Department in the absence of proof); Spolar, supra note 331, at A18 (stating that race will inevitably be an issue in the wake of the Rodney King beating trial in any criminal case involving white victims and a black defendant).

335. See, e.g., Fire and Fury, supra note 334 ("[J]ust beneath the surface of this case, there is a different kind of deep-seated rage, a racial distrust of the Los Angeles Police Department."). 
this strategy is an effort to put the State on the defensive as much as Simpson, by calling into question the racial bias of a main investigating officer ${ }^{336}$ and by making sweeping claims regarding the prosecution's handling of vital pieces of evidence. 337

In an effort to cast doubt on the prosecution's case at every turn, the defense has posed questions to prospective jurors that address their attitudes toward interracial marriage and racial discrimination $^{338}$ and toward Simpson as a celebrity. ${ }^{339}$ These past memories of Simpson may linger in the public consciousness despite the charges against him, and the defense seeks to uncover these memories and even to encourage them.

The defense's theory of the case must make sense of the cognitive dissonance many people experienced at the time of Simpson's arrest - the dissonance between a popular black celebrity and a man on trial for murder, and between his celebrity image and his actual life. ${ }^{340}$ Their strategy appears to be to play up this dissonance, until the dissonance becomes so loud that the image of Simpson the football player drowns out the image of Simpson the murderer. They hope that jurors, when faced with two such disparate images, will choose the familiar image of Simpson that prevailed prior to his arrest rather than Time magazine's darkened image of O.J. ${ }^{341}$

336. Fire and Fury, supra note 334; CNN \& Company, supra note 334; Nell Henderson, Defense Questions Work By Police at Crime Scene; Simpson Judge Rejects Use of Videotape From Site, WASH. Post, Feb. 10, 1995, at A3.

337. The defense, in keeping with its theory that Simpson is the victim of an overzealous, biased police inquiry, has filed several motions with the court - claiming, for example, that crucial blood evidence was mishandled or planted by the police or withheld from the defense, and that Simpson's premises were illegally searched on the night of the murders. See CNN \& Company, supra note 334; Henderson, supra note 336 (discussing police mishandling of evidence at the crime scene); Richard Lacayo, Flesh and Blood, TiME, July 11, 1994, at 26 (examining the wide array of material evidence connected to the case and the defense's reaction to it).

338. See, e.g., Andrea Ford, Simpson Jury Question List Probes Range of Attitudes, L.A. TIMEs, Oct. 1, 1994, at A1, A26 (proposing that defense lawyers would like to "ferret out" those who might have negative feelings toward Simpson based on race, among other factors).

339. Many of the questions posed to potential jurors focus "solely on Simpson and the relationship, or perceived relationship, people have with the former football star, sometime actor and sometime broadcaster." Spolar, supra note 331, at A18.

340. See id. at A18; Defense Portrays the 'Real O.J.'; Opening Statement Depicts Him as Proud Father, Generous In-Law, WASH. Post, Jan. 26, 1995, at A1 (contrasting the defense's portrayal of Simpson with the prosecution's portrayal of his "private face").

341. See Time, June 27, 1994, at cover. The magazine's altering of Simpson's photograph has not gone unnoticed in the media. See, e.g., Jefferson, supra note 332, at 1F; Barbara Reynolds, White-male thinking still dominates news coverage, USA TODAY, July 29, 1994, at 13A (describing the "doctored photo" as a "jarring insertion of racism into a story that now is bogged down with racial overtones"); Cynthia Tucker, Merchandised racism is still racism, Denv. Post, Sept. 7, 1994, at B-7; Mel Watkins, Hear the One About the Comics with a Cause?, N.Y. TimEs, Sept. 20, 1994, at C16 (recounting a black comic's joke about how the 
The resulting case theory is one in which race and status are closely linked by provoking images of an unjustly and tragically shattered American dream. ${ }^{342}$ The media has seized on these images, alternately characterizing Simpson as a traveler in a strange land, ${ }^{343}$ and then again as a modern-day Othello. ${ }^{344}$ In this way, Simpson may be seen as more a victim even than economically disadvantaged blacks - "those Simpson left behind on the other side of the tracks." 345

The defense also has paid careful attention to the connections between case theory and other aspects of the case. Simpson has altered his courtroom demeanor, humming showtunes and smiling for reporters in an effort to remind the public of the man it has known from afar for so long. ${ }^{346}$ In this way, Simpson has taken a leading role in the implementation of his case theory.

In a similar vein, the pending terrorism and conspiracy trial connected to the World Trade Center bombings has ethnic and religious implications for case theory. In that case, United States $v$. Rahman, the government has charged twelve Arab Muslims with conspiring to blow up the United Nations, the Lincoln and Holland tunnels, and other key spots in Manhattan, characterizing the plot as a "war of urban terrorism" masterminded by fanatic Arab religious fundamentalists. ${ }^{347}$ The defense has countered with several variations on an entrapment defense in which the defendants were easy scapegoats because of their religious and ethnic identities. In

Time cover "made the brother go from Bryant Gumbel to Wesley Snipes, and didn't think anybody would notice").

342. See Lynda Gorov, Simpson's strategy unclear: Experts guessing many defenses will be prepared, S.F. EXAMINER, Oct. 10, 1994, at A10 (examining bias-related defense strategies); Fire and Fury, supra note 334.

343. A newspaper report framed the case theory in this way: "He can be seen through the prism of race as a man who parachuted behind enemy lines, adopted the values of his natural antagonists and lived his life among aliens until he wound up in the middle of a nightmare ...." Lloyd Grove, Race and the Simpson Case, WASH. Post, June 27, 1994, at D1, D8.

344. The caption under the picture of O.J. and Nicole poses the question " Ebony and Ivory' or 'Othello'?" Id.

345. See Fire and Fury, supra note 334.

346. Spolar, supra note 331, at A18 (stating that Simpson's newly invigorated demeanor may tie into the defense strategy that "[i]t's difficult to be harsh with someone you know and like").

347. Randolph, supra note 152, at A1; Dennis Hevesi, Jurors in Bomb Plot Trial Questioned About Arrest, N.Y. Times, Feb. 10, 1995, at B2. One of the twelve defendants recently pled guilty in the case. Id. at B2. The charges are related to the separate World Trade Center bombing case, in which four Arab Muslims were convicted of committing various acts that led to the bombing that seriously damaged the World Trade Center, killed six people, and wounded more than one thousand. Randolph, supra note 152, at A1. A fifth defendant has recently been arrested in the case. Hevesi, supra, at B2. 
one version, the FBI's motive in the aftermath of the World Trade Center bombing was to create a plot that was doomed to fail. Thereby, the FBI was creating the opportunity to play the hero, as it was unable to do in the disastrous World Trade Center bombing. In another version, the government is charged with seeking to punish political views, not actions. ${ }^{348}$ Like the defense attorneys in the Simpson case and Colin Ferguson's pro se defense, the Rahman attorneys have adopted theories based on the bias in the criminal justice system and society that results in unjust prosecutions based on the identity of the defendants. ${ }^{349}$

This strategy confronts head-on the reality that the widely rumored reason for the bombing was anti-American sentiment and that the general public understood the case in terms of racist stereotypes - terrorist Arabs out to destroy American democracy. .350 The media has been accused of "Arab-Muslim bashing,"351 perhaps most vividly portrayed on the cover of the New Yorker. ${ }^{352}$ The picture featured on the New Yorker's cover on July 26, 1993, showed several "all-American" children playing at the beach with one lone

348. Richard Bernstein, Defense Charges Entrapment in Terrorist Conspiracy Trial, N.Y. Times, Feb. 1, 1994, at B3 (describing the entrapment defense); Mike Darning, Trial on "Urban Terrorism" Begins, CHI. TRIB., Jan. 30, 1995, at 5 (describing the political nature of the prosecution).

349. William Kunstler, who was disqualified as attorney for one of the defendants because of a conflict of interest, Richard Bernstein, Judge Disqualifies Kunstler Firm From Role in Bombing-Plot Trial, N.Y. Times, Aug. 26, 1994, at A1, planned a different defense: "[T] his was a political case, and the defense of the fifteen alleged conspirators had to be political; the case could not be won on legalities. ... The U.S. Government had put Islam on trial. My job was to defend the practitioners of this misunderstood religion, who, like any people who are different, are ostracized, feared, and persecuted." KunstLER, supra note 324, at 338 . In the underlying World Trade Center bombing case, this attention to perspective did not necessarily translate into an expanded role for the client in case theory development. The lawyer for defendant Salameh argued a theory that his client was an unwitting participant in the conspiracy, in direct contradiction to theories offered by the other three defendants, and despite Salameh's refusal to admit that he was a participant. Robert D. McFadden, Defendant in Bombing Trial Denounces Lawyer, N.Y. TIMEs, Feb. 22, 1994, at B1, B1-B2; Randolph, supra note 152, at A1. This defense "triggered a strong negative reaction" from Salameh at trial. Id.

350. See Jeff Barge, Sedition Prosecutions Rarely Successful, A.B.A. J., Oct. 1994, at 17 (quoting former Rahman defense attorney Ronald Kuby as saying, "[I]t's the government's idea for the jury to see one giant wad of Muslim terrorists forming a conspiracy stretching from New Jersey to Khartoum to Teheran and encompassing 800 million Muslims, give or take a few."); Randolph, supra note 152, at A1 (quoting a National Opinion Research Center pollster, who cited surveys "showing about 40 percent of Ámericans believe Islam condones or supports terrorism").

351. See Jack G. Shaheen, The Arab Stereotype and Prejudice: A Magazine Cover Deeply Wounds a Community, St. Louis Post-Dispatch, Nov. 23, 1993, at 11C.

352. See David Mazzucchelli; Castles in the Sand, New Yorker, July 26, 1993, at cover. 
crazed-looking Arab child about to demolish a sand-castle replica of the World Trade Center. ${ }^{353}$

The New Yorker cover is representative of popular sentiment surrounding the bombing and its aftermath and points to the need for case theory to confront and dispel these images. This may be especially important in a case like the World Trade Center case or the O.J. case - when the prosecution must rely heavily on circumstantial evidence.

While the defenses in all these cases have opened to mixed reviews and charges of racism from people of color and whites alike, ${ }^{354}$ they nonetheless demonstrate that the cramped view of case theory in academic discourse bears little resemblance to the case theories that are argued in courtrooms or those that have captured the popular imagination. Journalist William Finnegan, in a wonderful account of his role as a member of a jury in a criminal case and his subsequent investigation of the details of the case that never came out in court, explains that the jurors "told each other stories" because "the disputed facts before us would make sense only if we could imagine the worlds around them."355 Lawyers who offer theories that are keyed to the world unabashedly blend popular culture with legal doctrine in order to persuade juries that their clients are not ciphers. ${ }^{356}$ By urging us to look at cases - and clients - through the prism of race and other identities, ${ }^{357}$ these theories capture the life experiences of clients in a way that academic theory simply fails to do.

353. Id.; see also Shaheen, supra note 351, at 11C. New Yorker staff later met with representatives from the American-Arab Anti-Discrimination Committee to discuss future stories that the magazine could run in order to counter the offensive cover. Id.

354. CNN \& Company, supra note 334 (noting that the race-based strategy in the Simpson case could be a "very dangerous game"); Joel Dreyfuss, Rage Defense Plays Into White Hands, NewSDAY, Mar. 31, 1994, at A54 (arguing that the black rage defense furthers negative racial stereotypes); James Lileks, Hate America? Just Call Kunstler, Plain Dealer, Mar. 27, 1994, at 6C (accusing the black rage defense of appealing to "apologists for victimhood"); Christine Spolar, Blacks Given Promise of Fair Simpson Trial, WASH. Post, July 20,1994 , at A3 (citing the Urban League president's warning that the defense and prosecution think carefully before injecting race into the trial); Urban Survival, supra note 327, at A1 (criticizing the urban survival defense as racist). Others have seized on these defenses as opportunities to flaunt their own racism. See Tony Snow, Black Suspect is Not Alone in Racial Delusion, ARIz. RepuBlic, Dec. 17, 1993, at B7 (comparing Lani Guinier's views about voting rights to "a highfalutin echo of Ferguson's screams about Uncle Tomism"). For a discussion of the ethical constraints on case theories that appeal to race, gender, or ethnic bigotry, see Lubet, supra note 14, at 85-86.

355. William Finnegan, Doubt, NEw Yorker, Jan. 31, 1994, at 48, 51.

356. Lori Montgomery, Murder defense based on 'urban survival,' Hous. CHRoN., Oct. 24,1994 , at A15 (noting that a defense lawyer coined the term urban survival after learning about the concept on talk radio).

357. Grove, supra note 343 , at D1, D8. 


\section{B. Enhancing Client Participation and Control}

Case theory not only assists the lawyer and the fact finder in understanding what happened, but also helps the lawyer explain to the client what happened for the client's own benefit. Of course, the client knows what happened in the sense that he was present and has told a story about the event. But what the client experienced may differ from how he may come to understand that experience. If the lawyer hears the client tell a story that raises the issue of race, the lawyer can walk with the client through the facts in light of this theory.

The process of educating a client to the theory of his case is not without pitfalls, especially in light of a theory that argues for giving greater voice to client experience and expertise. This process, however, does not necessarily deny the validity of client experience. For example, Jay has a context for his particular experience from living his life as a black man. But he may not have thought about the incident systematically or imagined how it would be portrayed in a legal forum. Case theory can fit the pieces together and clarify events that were murky when they occurred.

Rather than taking power away from a client, this approach might have quite the opposite result. The client might suddenly realize, "Oh yeah, now I get it, this case is about race." While it may be unlikely that a lawyer would identify racism when a client failed to see it, more common is the situation when a client sees a highly relevant issue - like race - but neglects to raise it with the lawyer. The client may be motivated by a number of considerations embarrassment, a belief that the issue has no relevance to the proceeding, or simply a desire for privacy. While each of these motivations raises different issues about the extent to which the lawyer should respect client choices, some degree of lawyer intervention seems appropriate.

This process has value even if the theory is not ultimately presented in a legal forum. For a variety of reasons, Jay may reject telling a story about race in the courtroom but accept the race theory as explaining what really happened. By the same token, we as his lawyers may never have a chance to tell the race story, but we will be better lawyers if that story gives us more insight about the client. If we understand his experiences, we can better understand the choices he makes and use this understanding to shape other aspects of our representation. 
In addition to challenging the traditional concept of case theory, this new vision also revolutionizes the allocation of decisionmaking authority between lawyers and clients. Rather than choosing a case theory, as in the traditional model, or applying the "substantial impact" or related standard, as in the client-centered model, lawyers would routinely involve clients in decisions about case theory. The client would act as the locus of decisionmaking, while the lawyer would facilitate the process and implement the client's decision.

Although the traditional concept of case theory as a pivotal piece of legal strategy could also provide some role for clients, ${ }^{358}$ its legal and instrumental focus narrows the possibilities for client involvement. In contrast, the new vision creates a broader role for client expertise in both instrumental and noninstrumental terms, while still acknowledging that case theory matters a great deal to the ultimate result. Once case theory becomes more than just legal doctrine, clients have more to contribute than the facts about what happened. ${ }^{359}$

For example, a client may know as much as his lawyer does about whether a case theory based on race would persuade the jury. ${ }^{360}$ Whatever else lawyers may be expert at, there is little reason to think that a lawyer knows more about racism than does the average person. While a lawyer, through experience, may learn a great deal about how local juries react to different kinds of theories, this knowledge is not technical, nor is it exclusive. Awareness of racism is knowledge acquired in day-to-day life; it is hardly the exclusive province of lawyers.

Client expertise extends not only to developing a more winning case theory but also to assessing whether the theory satisfies other client objectives. Strategy, rather than being any action making it more likely that the client will win, becomes richer and more complex. At the same time, it becomes something clients are capable of weighing - perhaps even more capable than lawyers. Even if law-

358. See, e.g., Skolnick, supra note 151, at 65 (suggesting that the client may not accept the attorney's self-designated role as sole developer of strategy and tactics).

359. Another clinic case I supervised several years ago also demonstrates that by discussing facts - and the meaning of facts - clients can make important contributions to legal doctrine. In that case, the client was charged with malicious destruction of property for painting the words The landlord is a capitalist pig on the living-room wall of his apartment. The State was required to prove that our client's actions were malicious, and the students and I at first had difficulty framing his behavior as anything other than deliberate or malicious. By explaining the anger and frustration that fueled his behavior, however, the client taught us that his actions could instead be characterized as passionate.

360. Even Gerry Lopez, however, does not go so far as to say that clients know as much as their lawyers do about every aspect of legal representation. See LópEz, supra note 3, at 50 (distinguishing client practical knowledge from lawyer practical knowledge). 
yers are better than clients at assessing the likelihood that judges and juries will accept a particular argument, they are less expert than clients in knowing whether a case theory portrays the client in the way he wants to be portrayed, advances an argument that matters to him on a personal or political level, or makes room for his voice.

Finally, this model also values client choice for its own sake even if it does not lead to "better" results in either of the above senses. Rather than being relegated to the netherworld of "mere" strategy, case theory is the piece of the case that goes most to the heart of who the client is by determining how his story is told. Because the client is inside the story, the client has the right to decide how to tell it. ${ }^{361}$

This vision of case theory also leads to a much different lawyerclient counseling dialogue from the one envisioned by clientcentered theorists. Rather than focusing on the choice of procedural mechanism - trial, negotiation, or plea - as the key decision, the counseling dialogue would focus on case theory. Lawyers and clients would discuss the advantages and disadvantages of different case theories from many vantage points, including standard considerations such as which theory is most likely to prevail and whose testimony is necessary to support each theory.

The conversation would also turn to other, less instrumental concerns, such as how the client would be presented in each theory and whether he likes the story that the theory tells. In choosing one case theory over another, a client might seek vindication by asserting a particular right; he might even demonstrate that he cares more about vindication than he does about acquittal. ${ }^{362}$ Or a client might forgo an alibi defense because the alibi witness is his secret lover and also the spouse of his closest friend. ${ }^{363}$ A client might veto an insanity defense for reasons of personal integrity or choose a novel

361. See Menkel-Meadow, supra note 111, at 299 n.48 (describing Patricia Williams's narrative as a "plea for letting those 'inside' the story (the slaves who were property) make the laws about themselves"). By giving meaning to the client's story, case theory may be even more personal to the client than her own testimony, which is often cited as the paramount client interest. Berger, supra note 148, at 48 (stating that by testifying, the client seeks "literally to confront his accusers in the personalized arena of trial").

362. Luban, supra note 141, at 459 n.9. In his dissent in Jones, Justice Brennan explains why a criminal defendant might have an interest in case theory: "He may want to press the argument that he is innocent, even if other stratagems are more likely to result in the dismissal of charges or in a reduction of punishment. He may want to insist on certain arguments for political reasons. He may want to protect third parties." Jones v. Barnes, 463 U.S. 745, 759 (1983).

363. See supra note 146. 
legal defense with little likelihood of success on the chance that it might establish an important legal principle. ${ }^{364}$

Lawyers and clients might also discuss procedural mechanisms, but not in the conventional sense. While for a lawyer the choice of forum is driven by the goal of achieving the best legal result, each forum may also provide different opportunities for storytelling. A client who cares about how she is portrayed by case theory, or who has some other goal for case theory, would want to know how case theory would play out in a given forum. The answer to what the case is about also informs the choice of a particular legal procedure. For example, if a client seeks vindication, then a trial is typically a better alternative than a plea.

Once the collaborative energy of lawyer and client is focused on case theory, the question of who decides other issues assumes less importance because the choice of case theory makes many tactical decisions fall neatly into place. Once Jay decides to portray his case as a racial encounter, Rodriguez, Prince, and Williams become critical witnesses. ${ }^{365}$ Rodriguez can testify to the harassment he experienced, while all three men can testify about the racial overtones of the encounter between Jay and the guards.

Not only might theories change in this discussion, but also facts. Although some clients may make up facts to fit the case theory, ${ }^{366}$ this risk is outweighed by the contributions of truthful clients who know what facts matter. Case theory discussions are likely to reveal new factual dimensions because clients tell lawyers what they think is important ${ }^{367}$ and case theory reveals which facts matter. Once the lawyer broadens the frame of what is relevant, then the lawyer,

364. Strauss, supra note 117, at 325.

365. Although the decision about case theory would answer the question of which witnesses to call in many instances, this is not to say that the question has no meaning apart from case theory. The client might have other concerns about calling a witness and decide to forgo certain testimony, despite the impact on'case theory. See supra notes 144-46 and accompanying text.

366. For an illustration of this possibility, see supra notes 107-11 and accompanying text. Although it is commonly assumed that lawyers will know when clients are lying, see, e.g., BINDER ET AL., supra note 27, at 250-51, my experience has been that I rarely know whether clients are lying. In the story of Mrs. G., for example, we do not know whether she purchased school shoes or Sunday shoes. See supra note 215. Moreover, in addressing client lying, commentators have overlooked the empirical evidence about the degree to which other actors lie. These include police officers, see Myron W. Orfield, Jr., Deterrence, Perjury, and the Heater Factor: An Exclusionary Rule in the Chicago Criminal Courts, 63 U. CoLo. L. REv. 75, 95-114 (1992); Myron W. Orfield, Jr., The Exclusionary Rule and Deterrence: An Empirical Study of Chicago Narcotics Officers, 54 U. CHI. L. REv. 1016, 1049-51 (1987), and lawyers, see Lisa G. Lerman, Lying to Clients, 138 U. PA. L. REv. 659 (1990).

367. See BINDER ET AL., supra note 27, at 39. 
assisted by the client, will see new facts and emphasize those facts consistent with case theory.

In this dialogue, the client is truly a teacher and a contributor, not simply a recipient of the lawyer's noblesse oblige, as in the prototypical client-centered discussion about nonlegal consequences. The client engages deeply in the process of developing case theory because of what he knows and what the lawyer does not. The client might educate us in ways we cannot even imagine. Once we cede control over case theory to our clients, we must remember that as lawyers we may not be in the best position to understand their choices. We want desperately to ascribe a "why" to their words, yet our understanding is limited by our own frame of reference. We perceive legal strategy as the reason for their actions and only reluctantly consider other possible strategic goals. We forget that the legal consequences of their actions may be entirely accidental. They may have intended something entirely different.

Although we barely broke the surface of case theory discussions in our representation of Jay, his case suggests a number of advantages that might flow from broader client participation in developing and choosing case theory. Jay could have helped us consider the reconstructed theory in Part II, as well as other variations of the race case theory, and weigh the complex questions involved in choosing between these theories. Indeed, he would likely have a different kind of insight into these issues than we as lawyers have. Because the characterization of the participants changes subtly in each of these variations, he might prefer one role for himself, and another for the security guards. Perhaps in the process he might come to a different understanding of how he viewed the incident.

The reconstructed theory comes out swinging by painting the guards as racist and asking the judge or jury to find that the guards had a bad motive. Although it may capture the truth about the encounter, it asks the fact finder to choose between the worlds of the guards and Jay. The choice between good and evil may be too stark. It may cast Jay in too pure a light, when even by his own story he was verbally aggressive, perhaps obnoxious in tossing the coins, and ready to struggle with uniformed police officers. It does not explain away the store policy, which seems to have prohibited open bags, or the fact that Jay had shopped in the store before and not been bothered. Racism is difficult to prove and it is something about which we cannot always be certain. ${ }^{368}$

368. See, e.g., Kevin Sullivan \& Eugene L. Meyer, Restaurateurs Say Good Service Prevents Discrimination, WASH. Post, Sept. 5, 1993, at B6 (discussing different perceptions 
In one alternative, the guards were not overtly racist but unconsciously so. If asked, they might honestly say, "We did not stop him because he was black. We stop all shoppers who don't comply with the policy, whites as well as blacks and Latinos." In this version, the guards do not recognize that they in fact applied the policy selectively or that even if they initially stopped Jay for reasons unrelated to his race, they escalated the encounter with him in a way they would not have with a white man. They would not have called a white man "pal" or described him as pacing back and forth like a "caged animal."

In another alternative, Jay perceived the encounter as racist, whether or not it was, and this belief justifies his actions. This theory, while on its face complex, has much to offer. It does not require the judge or jury to choose between Jay's world view and that of the guards but instead asks them to recognize that Jay's view is valid, based on his experience as a black man and the experiences of other black men in this country. In this version, we cannot always know the existence of racism, which is at times a subtle and hidden phenomenon. What we can know is the subjective beliefs of the participants involved.

On the other hand, the risk of this theory is obvious. For many people, racism is either there or it is not. Statistics do not make a case for racism; racism exists only when there is direct evidence. Blacks and others are just "too sensitive" in imagining racism. They are really asking the rest of us to give them special treatment.

In representing Jay, we barely touched on these race theories, let alone discussed their advantages and disadvantages with our client. Yet any one of these theories opens up the possibility of new ways of thinking about the case in which legal doctrine serves as the backdrop, rather than as the primary shaper of events. We think of three possible theories - perhaps there are five or six variations, or even ten. ${ }^{369}$ These are possibilities that the traditionalists and the client-centered theorists cannot even imagine.

about whether race was a factor when three black women were moved from their restaurant table to accommodate a party of whites).

369. I learned this lesson well in the context of teaching in the clinic seminar offered to students in the Criminal Justice Clinic, the Women and the Law Clinic, and the Bridge Clinic - a clinic that "bridges" the issues raised in the other two clinics in the context of domestic violence. In that seminar, we assign an end-of-semester simulation that requires students to represent the plaintiff or the defendant in a civil assault and battery case. As part of that assignment, students are required to submit in writing a case theory of fifty words or less. While the only possible defense to the charge in the traditional sense is self-defense, there can be as many variations on a self-defense theory as there are students assigned to the defense role. 
By engaging in this process, we should expect a number of surprises. We might learn that the client wants nothing to do with the case theory as we have reimagined it. The client may not want to engage as much as the reconstructed model demands or reveal so much of himself to us and others. By putting more of himself in the case theory, the client lays bare more of himself and risks losing self-esteem if the fact finder rejects his view. This may have been an especially prominent consideration in Jay's case because the district court judge had already found him guilty.

Jay could deflect this risk by denying the validity of the fact finder's judgment; he could brand the judge or jury racist or simply label them naive. Yet this "out" may not always be enough, because the risk is not only a negative judgment in a single instance but a judgment that his experience of racism is false. Some clients might choose a less graphic case theory, even one not true to their experience, to avoid the pain of the fact finder passing judgment on their world view.

We might also learn that we have misconceived the case theory from the story Jay has told. As much as we might want the case to be about race, it may not be about race at all. It is the guards and the shoppers who testified for Jay who deliberately interjected the race issue. Perhaps we were too eager to seize on their characterization and turn it around to Jay's advantage. In telling his story, Jay never mentions race. In his eyes, the case may be about power or simple stupidity.

Nor are these possibilities mutually exclusive. The case could be about race and power and stupidity. Were the guards throwing their weight around because Jay was black, because he was the "accused" or the "subject," or because they were in uniform? In retelling the story in Part II, I proffer that the guards "punished [Jay] by teaching him a lesson about daring to speak out and about challenging authority." Presumably the "lesson" applies not just to black arrestees but to white arrestees as well. In the complex intersection of race and power, the variations are endless.

In this sense, the power of race as a case theory may also be its greatest pitfall. A lawyer concerned about social justice wants to validate the client's experience of the world and, indeed, may even look for racism when a client does not identify it as a factor. ${ }^{370}$ An

370. For striking accounts of the dilemma of activist lawyers, see Tigar, supra note 307, at 198 n.56 (quoting Lucy Parsons's speech to Clarence Darrow in the play MichaEL E. Tigar, Hay Market: Whose Name the Few Still SAY with Tears sc. xi, 1.48 (initial performance at Thorne Hall, Northwestern University (Oct. 23, 1987)) - "Your lawyer's ego wants 
awareness of race is an important insight to possess in a case, but it cannot always control the case's direction. Rather than holding onto a race case theory with a vengeance, the lawyer must be willing to back off if the client wishes. The lawyer must strike the difficult balance of recognizing the power of a race theory and being willing not to pursue it.

In addition, a more complete discussion of case theory might also change other decisions the client makes, such as whether to plead guilty or go to trial. In Jay's case, the question of whether he might have gone to trial if we had followed a more participatory model of decisionmaking still troubles me. Although Jay told us he was pleading guilty in return for the State's dropping the assault and battery charge - and I do not doubt that this played a factor in his decision - I do not know how his interpretation of our case theory affected his decision.

Earlier, when the students asked Jay whether he wanted us to characterize the incident as racially motivated, he said a race theory made him uncomfortable. The students told me Jay was reluctant to discuss the reasons, and I did not press them further. I now wonder whether Jay would have plead guilty if we had further explored this question with him. What did his discomfort with a race case theory mean? What other options did he see? Why did he tell a story at the trial that avoided the question of race? If we had discussed these issues, Jay might have been more hopeful about his case or might have better understood the implications of a race theory.

\section{Recognizing Lawyer Life Experience}

Finally, in this process, we might also learn that much of how we as lawyers shape case theory has to do with who we are. ${ }^{371}$ It is not that we dominate our clients, as critical theorists argue, but rather

you to think you stand at the center of every event by which the world is changed"); Nancy D. Polikoff, Am I My Client?: The Role Confusion of a Lawyer Activist (May 1993) (unpublished manuscript, on file with author) (exploring lawyer-client control issues in the context of lawyers and clients engaged in civil disobedience regarding lesbian and gay rights and AIDS issues).

371. For excellent examples of how lawyers' life experiences can affect their understanding of cases, see Getman, supra note 307, at 583 (arguing that a black female student had a better understanding of Native American parents' dilemma in seeking health care for their child than did her white counterparts); Peter Margulies, The Mother with Poor Judgment and Other Tales of the Unexpected: A Civic Republican View of Difference and Clinical Legal Education, 88 Nw. U. L. REv. 695, 716-23 (1994) (arguing that law students can offer fresh perspectives that clinical teachers lack); Polikoff, supra note 370 (exploring conflicts arising from the close connection between the author - an activist lesbian lawyer and law professor - and her lesbian and gay clients). 
that we are either more or less creative than our colleagues, more or less risk averse, more or less fearful of taking on the system, or have more or less life experience with the theory in question. By engaging with the client in these discussions, we might come to know more about ourselves, becoming better lawyers in the process.

Jay's case raises especially thought-provoking issues about how lawyers approach case theory based on their own life experiences and attitudes. Both the students and I are white. From the beginning of the case, I eagerly seized on the race case theory, anticipating that the client would want us to pursue this theory with abandon and feeling excited about the possibilities of putting the racist guards on trial. In contrast, the students were downbeat about the possibilities, even before they met with the client. They seemed uncomfortable talking about the case in racial terms and were quick to argue that the jury would never believe our theory. They viewed the stories of Rodriguez, Prince, and Williams as inconsistent and full of holes and, after interviewing them in person, reported that the men were not "credible" and would make poor witnesses. They found especially persuasive a conversation with the assistant public defender who represented Jay in the trial, who reported the courtroom clerk's belief that Jay's witnesses had "conspired" with him to steal from the store.

Although I pushed them hard on their assumptions, pointing out that the State's witnesses told stories that were inconsistent and irresolvable and that our theory might resonate with members of the jury who had themselves been treated poorly, they moved little from their initial judgment. Nor were they persuaded by my suggestion that the clerk's comments could themselves reflect thinly veiled racism and that our own racial biases could affect our judgment about case theory. They said they could not understand why the client had gotten so angry.

At the time, I was frustrated by our differences and was inclined to think that the students were insensitive to the pervasive power of race. They in turn probably thought that I was overly interventionist, politically correct, and dogmatic. Looking back on the case, I believe we were both wrong. We were separated not solely by differing sensitivities to race issues but instead by our ability to relate to the client's anger.

As I observed both students in the classroom and supervision meetings, they were polite, mannerly, and deferential to authority. They attended every class, and their work was meticulous. From 
what I knew of their backgrounds, they came from traditional families and had set their sights on law school early on. ${ }^{372}$ Despite the pressures of the clinic, I had never seen them express anger or even annoyance, and I could not imagine them screaming or yelling in a public place. While I do not pretend to know their inner struggles, I do not think they could imagine themselves ever acting out in a store, no matter what the provocation.

My experience was different. At some level, I felt I could understand the client's anger, even if it were the result of misperceived racism. Although, like most law professors, I lead a life that is quite conventional in many respects, in other respects it is not. I am a lesbian, and like every lesbian or gay person, I have experienced discrimination as a consequence of my sexual orientation. In response, I have gotten angry, I have cried, and I have marched in the streets. I always feel like an outsider, and as a result, I have a deep appreciation for other people who may share an outsider's perspective.

I also have been badly treated in stores. When I wear jeans and a t-shirt and store personnel are rude to me, I assume they think I am younger than my actual age, or that I have no money to spend, or both. At times, I am convinced that $I$ have been treated rudely because I look like a lesbian. If someone asked me for proof, I could not provide it, but at a deep level I know it to be true. As a consequence, I think that I respected the client's judgment, right or wrong, about his encounter in the store.

When the client decided to plead guilty, the students expressed no concern that a man who had maintained his innocence was doing an about-face. Although they said they had not concluded that he was guilty, I believe they thought he was. In contrast, I felt remorseful, and still do, that by allowing him to plead guilty we had somehow fundamentally failed to honor his worth as a person. I cannot say that the connection I felt with the client was a good thing for our representation. My feelings may have clouded my judgment about the value of a race case theory or made me too quick to see the possibilities of this theory when even the client was urging us to back away. What I can say is that my experience made me view the case in a fundamentally different way.

372. I also know that the students had attended parochial schools and believe that this background also may have influenced their perception of our client. Because I grew up in a Catholic community and many of my friends attended parochial schools, I have strong views about the impact of this kind of education, but I recognize that these views are also unfair biases. 
Sexual orientation also figured into an aspect of representing Jay even more clearly connected to case theory. Following my usual practice in the clinic, I did not meet the client or his witnesses until our court appearance on his behalf. Although Jay had decided to plead guilty before the circuit court trial date and we had confirmed the plea bargain with the prosecutor, the students had asked Prince and Rodriguez to attend court in the unlikely event that the plea fell through. When I met Prince and Rodriguez at the elevators outside the courtroom on the morning of court, I realized they were gay. Although a number of observations contributed to this conclusion, at bottom my intuition, not a list of "facts," led me to this realization.

We all stood together with the client outside of the courtroom waiting for the court to call our case. As I watched Jay interact with Prince and Rodriguez, it dawned on me that he also was gay. I sensed this conclusion more than I knew it. ${ }^{373}$ I also sensed that Prince and Rodriguez were a couple. The case was called a few minutes later, and we all went into the courtroom.

Since the case ended, I have thought a great deal about how my awareness of the sexual orientation of the client and his witnesses has affected how I look at the case. At the time I did not think of this awareness as a kind of case theory; I now do. While race was an obvious theme, sexual orientation resided in the background. Sexual orientation is almost always more invisible than race, yet it can have a profound effect on how we view what happened. Even when sexual orientation is not directly at issue, as it would be in a military discharge case or in a case challenging a lesbian mother's right to raise her child, it provides a lens for understanding what happened.

Thinking about the case in terms of sexual orientation changes my view of the encounter between Jay and the guards and between Rodriguez and the guards. Of the three men, Rodriguez seemed to me to be the most "obviously" gay. Perhaps the guards stopped him out of overt homophobia, or out of a less conscious realization that he was somehow "different." Although Jay's sexual orientation seemed to me more hidden, the guards could have been motivated by similar considerations. Thousands of gay men and lesbians have died as a result of individuals acting on homophobia; it is not

373. While I am fairly confident of the accuracy of this perception, I of course do not know that the client or his witnesses were gay. I use the terms knowledge, realization, and awareness to capture my belief that they were gay. 
hard to imagine that homophobia, conscious or unconscious, might lead a guard to stop someone in a store.

Sexual orientation might also explain why Prince and Rodriguez came to Jay's assistance and waited at the jail for him to be released. The State's unstated but implicit explanation for their involvement was that Jay and his witnesses were members of racial minority groups. Sexual orientation might provide an alternative explanation. So too might sexual orientation explain why the students viewed Prince and Rodriguez as unreliable.

Indeed, Jay may have reacted as he did to the guards' harassment because he perceived a homophobic slur - real or unintended. The term punk - the term Dirk used in hassling Jay and Rodriguez - is a somewhat dated reference to male homosexuals and is still employed by some African Americans. I was unaware of this connotation until Margaret Montoya, a Latina clinical colleague, read a draft of this article and suggested this interpretation based on her experience in the African-American community. This turn of events once again demonstrates the key role that life experience can play in lawyers' understanding of their clients and cases.

The choice between a race theory and a sexual orientation theory is not an either-or choice. Events may have transpired as they did for reasons of both sexual orientation and race - or neither.

Many questions about the possible implications of a theory based on sexual orientation remain unanswered because I did not raise the issue with the students or the client. I did not see the client again once the case ended, and I made a conscious decision not to raise it with the students. Because the client had not raised the issue of his sexual orientation with us, my guess was that he did not wish to discuss it, and for me to discuss it with the students would violate his privacy. Of course, I cannot conclude from the fact that he did not raise the issue that he would not wish us to raise it, but the safest choice was to leave the issue alone, given that it could have no effect on the outcome of the case.

Had we still been developing case theory at the point when I became aware of the issue of sexual orientation, the question of whether to pursue it would have been more complicated. On the one hand, the client should have the choice about whether to argue this theory. On the other hand, the theory would not likely help the client win his case, given societal homophobia and a jury's likely inclination to see the shared sexual orientation of the three men as evidence of bias, rather than simply as a shared experience. Although a client in Jay's shoes might have noninstrumental rea- 
sons to raise the question of sexual orientation, Jay was an unlikely candidate to assert these reasons, given his absolute silence on the issue.

Moreover, there is potentially a very high cost to discussing sexual orientation issues with a client who wants to keep his sexual orientation secret. Simply raising the issue with the client might be devastating if he believes that by remaining silent he can control who has access to this information. The client might even prefer to lose his case by abandoning a potentially winning issue of sexual orientation rather than know that his lawyer has recognized something so personal about him. ${ }^{374}$ If I could recognize this as his lawyer, how obvious must it be to the rest of the world?

While a theory based on sexual orientation, like a race theory, might be more true to the client's life experience, it may not be a better theory in any real sense. Indeed, who the client is may itself be problematic, given the level of homophobia in this country and the risk of presenting this theory to a judge or jury. This risk may be even greater for a client who is both black and gay. While a theory premised on race and sexual orientation may most fully capture the client's experience, we might nonetheless abandon it.

Perhaps the most important lesson of the story is that if we are to take life experience seriously in developing case theory, we must look beyond race to other kinds of theories that may not be so immediately apparent but that are potentially relevant. Given the prevalence of racial issues in the criminal justice system, ${ }^{375}$ a competent lawyer should always consider the impact of race, but she must also go further. The impact of other fundamental characteristics such as gender, class, and sexual orientation may be less obvious but equally important in offering explanations in cases. Unless lawyers consciously look for these perspectives, they may miss them, even when the client's view of what happened is shaped by this perspective. The client does not look for this perspective but simply sees the world that way.

374. Epstein, supra note 148, at 30 (arguing that a closeted gay client should have the right to reject a self-defense theory that would require him to admit his presence at a gay bar, in favor of a weaker misidentification defense).

375. See Sheri Lynn Johnson, Racial Imagery in Criminal Cases, 67 Tul. L. Rev. 1739, 1794 (1993) (advocating an ethical prohibition against racial imagery in criminal cases); White, supra note 10, at 1506 (noting the prevalence of hierarchies of race in criminal law). 


\section{Conclusion}

An understanding of case theory is a critical component of good lawyering. The traditional concept of case theory, however, ignores the reality of client life experience and provides no role for clients in developing and shaping case theory.

Surprisingly, the client-centered perspective adds little to the traditional understanding. These writers do not seriously challenge the traditional concept of case theory, and while they suggest an expanded role for clients in litigating their cases, most of their proposals overlook the key role of case theory in strategy decisions.

In contrast, the critical lawyers' attention to voice, narrative, and the power dynamics between lawyers and clients says much that matters to case theory. Cases are about clients, not lawyers. They are not just about what happened but about client life experiences as well. Client voice shapes the meaning of facts and changes the nature of what the case is about.

Yet the critical lawyers' metaphors of power and competing lawyer and client narratives miss much that is important to case theory. To realize the rich possibilities of storytelling, lawyer and client narratives must come together to capture the best of both client and lawyer experience.

- As I have reconstructed case theory, it is a lens for shaping reality in light of the law - a lens that explains the facts, relationships, and circumstances of the client and other parties in the way that can best achieve the client's goals. This reality comprehends client life experience and also recognizes the expertise that both clients and lawyers can contribute to developing case theory. By looking beyond doctrine, case theory operates as a way to view the slice of the world that becomes the case. The possibilities of imagination are almost limitless. 